\title{
IDENTIFICAÇÃO E CARACTERIZAÇÃO DE ÁREAS E COMUNIDADES COM POTENCIAL PARA O DESENVOLVIMENTO DE SISTEMAS COMUNITÁRIOS DE PRODUÇÃO FLORESTAL NO ESTADO DO AMAPÁ
}

\author{
MAURO JOSÉ CAPÓSSOLI ARMELIN
}

Dissertação apresentada à Escola Superior de Agricultura "Luiz de Queiroz", Universidade de São Paulo, para obtenção do título de Mestre em Ciências, Área de Concentração Ciências Florestais.

P I R A C I C A B A

Estado de São Paulo - Brasil

Dezembro - 2001 


\title{
IDENTIFICAÇÃO E CARACTERIZAÇÃO DE ÁREAS E COMUNIDADES COM POTENCIAL PARA O DESENVOLVIMENTO DE SISTEMAS COMUNITÁRIOS DE PRODUÇÃO FLORESTAL NO ESTADO DO AMAPÁ
}

\author{
MAURO JOSÉ CAPÓSSOLI ARMELIN \\ Engenheiro Florestal
}

Orientador: Prof. Dr. VIRGíLIO MAURÍCIO VIANA

\author{
Dissertação apresentada à Escola Superior de \\ Agricultura "Luiz de Queiroz", Universidade de São \\ Paulo, para obtenção do título de Mestre em \\ Ciências, Área de Concentração Ciências Florestais.
}

P I R A C I C A B A

Estado de São Paulo - Brasil

Dezembro - 2001 
Dados Internacionais de Catalogação na Publicação (CIP) DIVISÃO DE BIBLIOTECA E DOCUMENTAÇÃO - ESALQ/USP

\section{Armelin, Mauro José Capóssoli}

Identificação e caracterização de áreas e comunidades com potencial para o desenvolvimento de sistemas comunitários de produção florestal no Estado do Amapá / Mauro José Capóssoli Armelin. - - Piracicaba, 2001.

p. 131 p. : il.

Dissertação (mestrado) - - Escola Superior de Agricultura Luiz de Queiroz, 2002

Bibliografia.

1. Amapá (AP) 2. Desenvolvimento sustentável 3. Estado (Política) 4. Manejo florestal I. Título

CDD 333.715

\section{"Permitida a cópia total ou parcial deste documento, desde que citada a fonte - $O$ autor"}




\section{DEDICO}

este trabalho aos meus pais, Marta e Domingos, pela determinação e coragem na formação de uma verdadeira família, aos meus irmãos Ana Paula e Matheus, por terem sido atores importantes em meu processo de desenvolvimento pessoal e, a minha sobrinha e afiliada, Laura, que hoje representa a renovação em nossa família, alimentando esse ciclo virtuoso criado por meus pais. 


\section{AGRADECIMENTOS}

A Prof. Adriana Maria Nolasco, pela orientação e acompanhamento em todas as fases de desenvolvimento, desde o esboço do primeiro questionário até a versão final, deste trabalho.

Ao CNPq, pela bolsa concedida por 2 anos.

Ao Prof. Virgílio Viana, pela orientação e principalmente pela oportunidade a mim dada, em 1995, de estagiar no Proj. Caixeta.

Ao grande pesquisador e amigo Edson Vidal e sua esposa Gerlane, minha família na Amazônia, por tudo que fizeram por mim e por este trabalho. Não tenho nem palavras para expressar minha gratidão a esses dois.

A Adalberto Veríssimo, pela confiança e amizade, e pela oportunidade de participar de um dos projetos do Imazon, que foi a base para esta dissertação.

A Frank Pantoja, amigo e companheiro das expedições de campo e coleta de dados para este trabalho.

Ao amigo esalqueano Lentilha, Marcos Lentine, que além de voltar sozinho ao Amapá para melhorar a amostragem também fez a tabulação dos dados e processamento primário das informações. Melhor que isso, só se tivesse escrito a dita tese para mim!!!

Ao Eng. Ftal. Rodney Reis, pelos mapas e análises em SIG, que foram fundamentais para o desenvolvimento deste projeto.

A Elson Vidal, secretário executivo do Imazon, pela atenção e dedicação na solução dos problemas administrativos do projeto.

A Amigos da Terra - Amazônia Brasileira e Roberto Smeraldi, pela oportunidade de trabalhar na Amazônia.

Ao Imazon, um dos mais competentes institutos de pesquisa da Amazônia. 
Aos técnicos do RURAP e FNS, pelas informações e dedicação ao trabalho.

A Alcione Carvalho, pelo empenho na viabilização deste projeto junto ao Governo do Estado do Amapá.

A Leandro Pinheiro (VazPi), pela amizade e orientação pessoal sempre presente durante os anos de elaboração desta tese.

A Maria José Gontijo, pela aposta que fez ao me convidar para participar da organização da II Of. de Manejo Florestal Comunitário, mas principalmente pela coragem e determinação de continuar promovendo estes importante encontros.

A amiga Tania Landesman, pelos vários empurrões para a retomada deste trabalho no tumultuado começo do ano 2000. Valeu!!

A Alessandra Arantes, namorada, companheira e amiga que repartiu comigo os últimos passos na conclusão de mais esta etapa de minha vida profissional. 


\section{SUMÁRIO}

Página

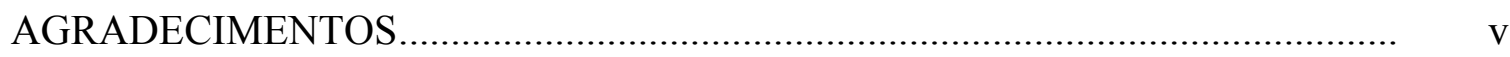

LISTA DE FIGURAS ……..................................................................... vii

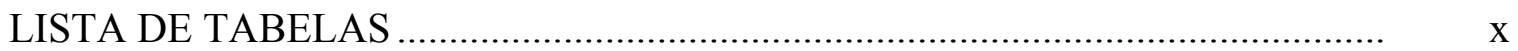

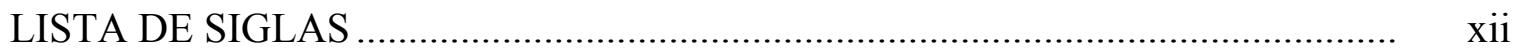

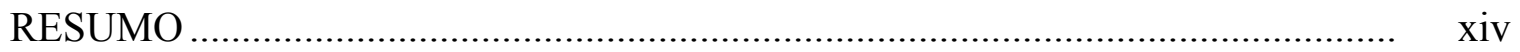

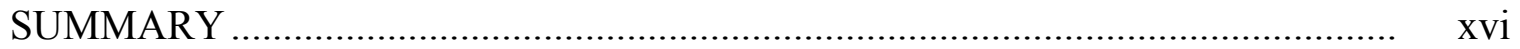

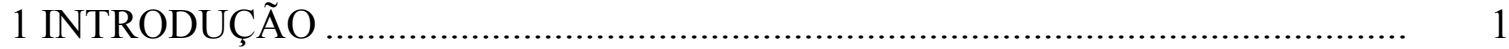

1.2 Objetivos .......................................................................................

2 REVISÃO DE LITERATURA ........................................................................ 4

2.1 Amazônia, Desenvolvimento e políticas públicas .................................................. 4

2.2 A dinâmica do desmatamento na Amazônia, o papel da agricultura e da pecuária 7

2.3 Manejo florestal e extrativismo na Amazônia ....................................................... 10

2.4 Espaço comum e comunidades tradicionais......................................................... 13

2.5 Manejo Florestal Comunitário ……………………………………………..... 15

2.6 Produção florestal e desenvolvimento no estado do Amapá.................................... 16

2.7 Caracterização do Estado do Amapá............................................................... 18

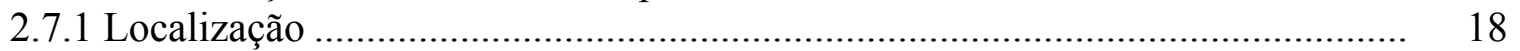

2.7.2 Divisões fisiográficas ............................................................................... 19

2.7.3 Recursos naturais ........................................................................... 20

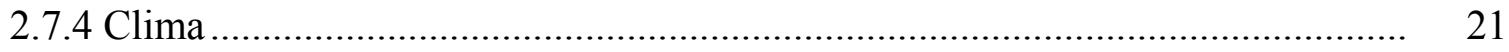

2.7.5 Vias de transporte ............................................................................. 21

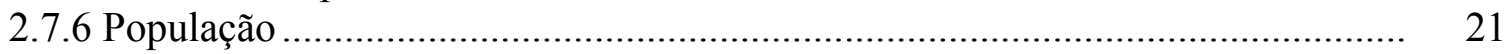

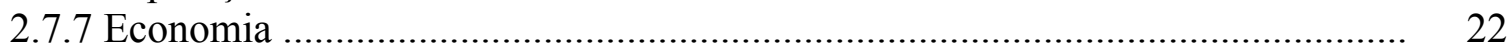

2.7.8 Energia …...................................................................................... 23

3 MATERIAL E MÉTODOS _......................................................................... 25

3.1 Critérios para priorização de comunidades …………………………………...... 26

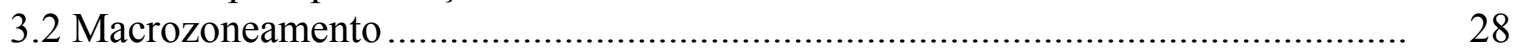

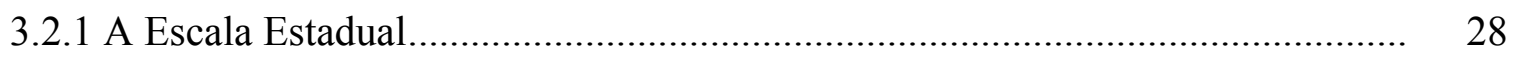

3.2.2 Escala Municipal .............................................................................. 34

3.3 Levantamento sócio-econômico...................................................................... 36

4 RESULTADOS E DISCUSSÃO .............................................................. 39

4.1 Macro-zoneamento através da geo-exclusão .................................................... 39 
4.2 Os municípios potenciais ………................................................................ 40

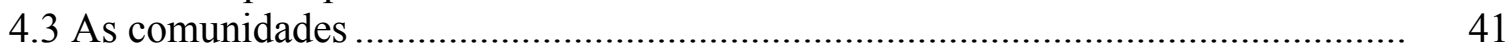

4.3.1 Formas de ocupação das áreas ......................................................................... 51

4.3.2 Atividades econômicas.............................................................................. 53

4.3.3 Organização social ............................................................................... 54

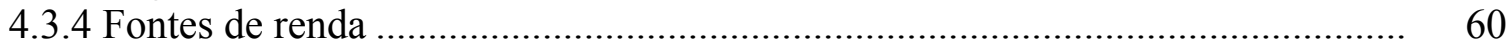

4.3.4.1 Atividades econômicas das comunidades de terra firme ................................. $\quad 60$

4.3.4.2 Atividades econômicas das comunidades de várzea......................................... 61

4.3.4.3 Atividades econômicas das comunidades do Arquipélago do Bailique........... 62

4.3.4.4 Fontes externas de renda. ......................................................................... 63

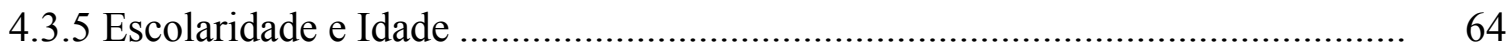

4.3.6 Situação fundiária ...................................................................................... 68

4.3.7 Evolução do uso da terra ..............................................................................

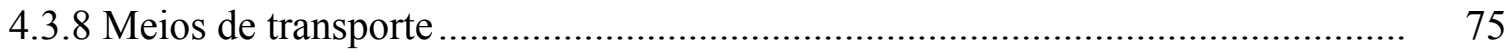

4.3.9 Infraestrutura comunitária....................................................................... 79

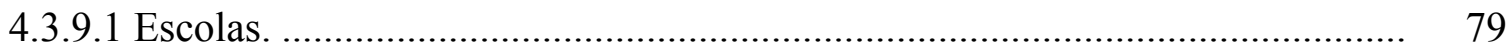

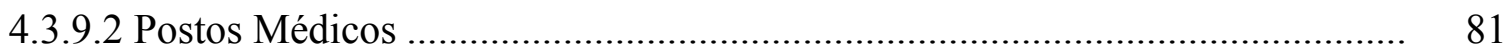

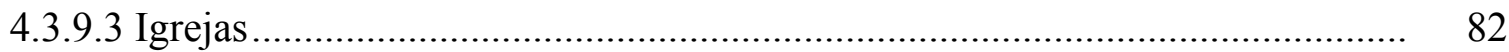

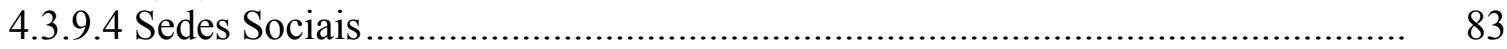

4.3.9.5 Comércios .................................................................................. 83

4.3.9.6 Energia Elétrica .................................................................................. 83

4.3.10 Assistência técnica ................................................................................. 85

4.3.11 Acesso a crédito ................................................................................... 86

4.3.12 Produção florestal.................................................................................. 89

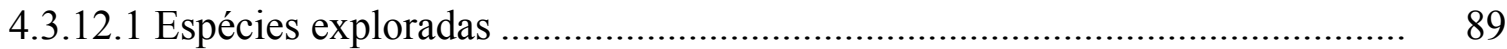

4.3.12.2 Destino da produção................................................................................... 90

4.3.12.3 Volume de madeira processada.................................................................. 91

4.3.12.4 Tipo de Exploração ................................................................................ 92

4.3.13 O que entendem por manejo florestal ........................................................... 96

4.3.14 As expectativas em relação ao desenvolvimento ……………………………..... 98

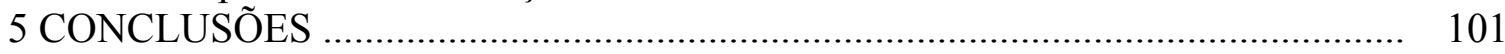

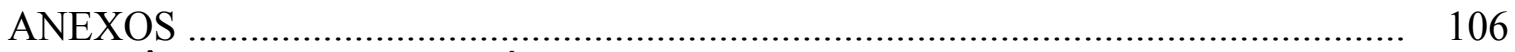

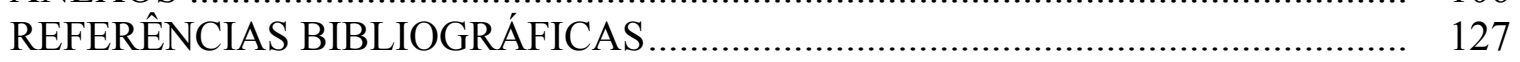




\section{LISTA DE FIGURAS}

Página

1 Localização geográfica do Estado do Amapá ......................................................... 18

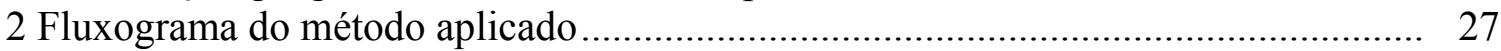

3 Localização das áreas com florestas do Estado do Amapá (IBGE, 1997)................ 30

4 Localização das unidades de conservação do Estado do Amapá (Fonte: Veríssimo et al., no prelo) ........................................................................................... 31

5 Alcance econômico da atividade madeireira no Estado do Amapá (Fonte:

Veríssimo et al., no prelo) ................................................................................. 32

6 Divisão política e áreas prioritárias do Estado do Amapá ......................................... 33

7 Área de extração economicamente viável para todas as espécies comercias.............. 40

8 Comunidades visitadas na região dos municípios Laranjal do Jarí, Vitória do Jarí e região ocidental de Mazagão............................................................................. 43

9 Comunidades visitadas no município de Mazagão e na face oriental do Vitória do

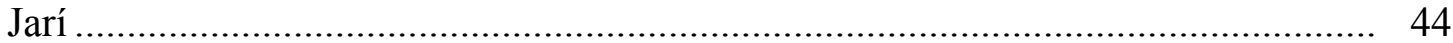

10 Comunidades visitadas na região central do Amapá.............................................. 45

11 Comunidades visitadas na região do arquipélago do Bailique................................ 46

12 Distribuição das comunidades amostradas por região ......................................... 47

13 Número de comunidades por classe de famílias e \% acumulada de famílias. ......... 47

14 Localização das famílias das comunidades visitadas............................................. 48

15 Origem das famílias componentes das comunidades......................................... 49

16 Número de comunitários separados por classe de idade, crianças, jovens, adultos

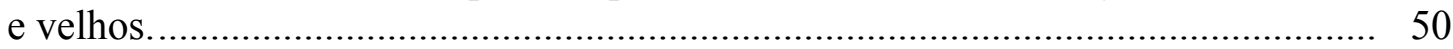

17 Forma de ocupação a terra pelas famílias .......................................................... 52

18 Atividades coletivas internas das comunidades ............................................. 58

19 Freqüência das principais atividades econômicas das comunidades por região de amostragem.

20 Freqüência das atividades econômicas das comunidades por região de amostragem.

21 Tipos de fonte de renda externas à comunidade ................................................ 64

22 Escolaridade dos comunitários de 21 a 40 anos de idade ....................................... 65

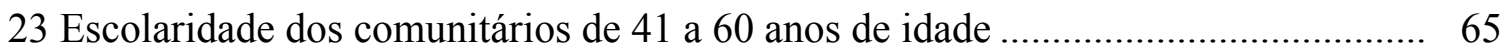

24 Tempo de exploração das florestas pelas comunidades........................................ 73 


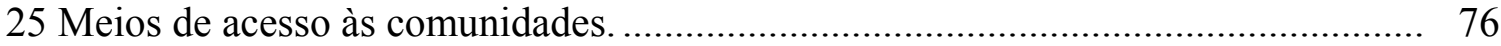

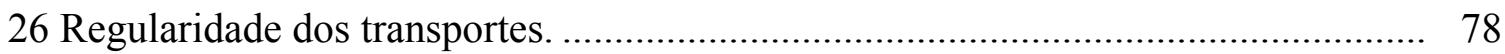

27 Educação oferecida nas comunidades visitadas............................................ 80

28 Fontes de energia elétrica nas comunidades visitadas. ....................................... 84

29 Tipo de exploração florestal nas comunidades de terra firme............................... 93

30 Tipo de exploração florestal nas comunidades de várzea..................................... 94

31 Tipos de extração, forma de transporte de toras e madeira serrada e processamento de madeira no Estado do Amapá (Veríssimo et all, 1999)............. 95

32 Atividades citadas como alternativas de desenvolvimento para a comunidade....... 98

33 Modelo de serraria comunitária do Estado do Amapá, município de Mazagão. .... 107

34 Transporte de madeira com caminhão "toreiro", em floresta de terra firme........... 107

35 Sistema de transporte de toras pelo rio, em florestas de várzea........................... 108 


\section{LISTA DE TABELAS}

Página

1 Dados gerais do Estado do Amapá

2 Número de localidades existentes nos municípios do Estado do Amapá (Fonte:

FNS, 1999), número de comunidades amostradas e intensidade amostral ........... 42

3 Comunidades amostradas, agrupadas por município ............................................ 46

4 Número médio de componentes das famílias separadas pela região de ocupação..... 54

5 Principais atividades econômicas dos entrevistados ................................................ 59

6 Número de comunidades que possuem ou participam de organizações sociais e idade média destas organizações ................................................................... 61

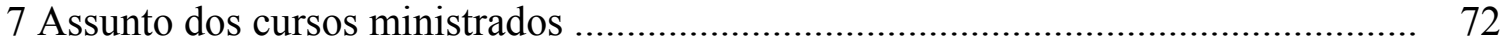

8 Freqüência dos diferentes documentos fundiários encontrados .............................. 74

9 Tipos de cobertura vegetal citadas pelas comunidades ........................................ 78

10 Veículos de transporte utilizados pelas comunidades ........................................ 82

11 Igrejas existentes nas comunidades ................................................................. 87

12 Comunidades que já receberam Apoio a Fundo Perdido, identificadas pelo número do questionário

13 Lista das comunidades que receberam financiamentos bancários, época e em que foi utilizado, identificadas pelo número do questionário ................................... 93

14 Volume e consumo de madeira processada mensalmente para as serrarias das comunidades amostradas

15 Iniciativas de MFC e os tipos de exploração utilizado ....................................... 101

16 Municípios cujas florestas estão dentro da área de viabilidade econômica de exploração e suas comunidades potenciais para o desenvolvimento do manejo florestal comunitário

17 Comunidades que poderiam servir de projeto piloto para o processamento de madeira no âmbito do programa do governo 
18 Comunidades visitadas no levantamento, coordenadas geográficas obtidas com auxílio de GPS e período em que foram conduzidas as entrevistas (agosto de 1999 e/ou outubro de 2000).....

19 Número de famílias e área total estimada das comunidades amostradas............... 125 


\section{LISTA DE SIGLAS}

AMAEX-CA
AMAJA
ASTEX-CA
APRONORTE
ATEXMAR
BANAP
BANESPA
BASA
CEA
COOPENORTE
COOPESSERRA
CNPT
ELETRONORTE
EMBRAPA
FAOR
FLORAP
FNO
FNS
FSC
GEA
IBAMA
IBGE
IEPA
IMAZON
INCRA
INPE
MFC
MFPE
PROCERA
POEMA
PRODEX
PROFLORESTA
PRONAF
PRORURAL
REBRAF
RESEX-CA
RURAP
SEAF
SEBRAE
SEICOM

Associação dos Moradores Agroextrativistas do Baixo CaJarí

Associação Mista dos Agricultores Extrativistas de Laranjal do Jarí

Associação de Moradores da Reserva Extrativista do Rio CaJarí

Associação dos Produtores Rurais da Perimetral Norte

Associação dos Trabalhadores Agroextrativistas do Maracá

Banco do Estado do Amapá

Banco do Estado de São Paulo

Banco da Amazônia

Companhia de Eletricidade do Amapá

Cooperativa Agroextrativista dos Produtores Rurais da Perimetral Norte

Cooperativa Agroextrativista dos Produtores do Município de Serra do Navio

Centro Nacional de Desenvolvimento Sustentado das Populações Tradicionais

Centrais Elétricas do Norte do Brasil S.A.

Empresa Brasileira de Pesquisa Agropecuária

Fórum de ONG's da Amazônia Oriental

Plano estratégico "Florestas do Amapá para o desenvolvimento sustentável"

Fundo Constitucional de Financiamento do Norte

Fundação Nacional de Saúde

Forest Stewardship Council - Conselho de Manejo Florestal

Governo do Estado do Amapá

Instituto Brasileiro do Maio Ambiente e dos Recursos Naturais Renováveis

Fundação Instituto Brasileiro de Geografia e Estatística

Instituto de Estudos e Pesquisas do Estado do Amapá

Instituto do Homem e Meio Ambiente da Amazônia

Instituto Nacional de Colonização e Reforma Agrária

Instituto Nacional de Pesquisas Espaciais

Manejo Florestal Comunitário

Manejo Florestal em Pequena Escala

Programa Especial de Crédito para a Reforma Agrária

Programa Pobreza e Meio Ambiente na Amazônia

Programa de Apoio ao Extrativismo Vegetal

Programa de Apoio ao Desenvolvimento Florestal

Programa Nacional de Fortalecimento da Agricultura Familiar

Programa de Apoio à Pequena Produção Familiar Organizada

Rede Brasileira de Agrofloresta

Reserva Extrativista do Rio CaJarí

Instituto de Desenvolvimento Rural do Estado do Amapá

Secretaria de Agricultura, Floresta, Pesca e Abastecimento do Estado do Amapá

Serviço de Apoio à Micro e Pequena Empresa

Secretaria de Indústria, Comércio e Mineração do Estado do Amapá 
SEMA

SENAR

SEPLAN

TERRAP
Secretaria de Meio Ambiente do Estado do Amapá

Serviço Nacional de Aprendizagem Rural

Secretaria de Planejamento do Estado do Amapá

Instituto de Terras do Amapá 


\title{
Identificação e caracterização de áreas e comunidades com potencial para o desenvolvimento de sistemas comunitários de produção florestal no Estado do Amapá
}

\author{
Autor: MAURO JOSÉ CAPÓSSOLI ARMELIN \\ Orientador: Prof. Dr. VIRGÍLIO MAURÍCIO VIANA
}

\section{RESUMO}

Muitas são as formas para se promover o desenvolvimento, mas poucas são as que podem privilegiar a maioria das classes sociais. O desenvolvimento sustentável é um conceito aprimorado do desenvolvimento hoje conhecido, que busca além da sustentabilidade dos recursos naturais, necessários aos seus processos, também a divisão dos lucros com a totalidade do bolo social. Hoje, com este modelo de desenvolvimento predominante, o único resultado dividido com toda a sociedade são os problemas sócioambientais criados. A finalidade deste trabalho foi procurar conhecer um pouco mais as comunidades do Estado do Amapá, para assim tentar embasar as políticas públicas de desenvolvimento do atual governo estadual, sendo esta a demanda apresentada pelo próprio governo, quando em 1998 solicitou ao Instituto do Homem e Meio Ambiente da Amazônia - Imazon - o levantamento do setor madeireiro do Amapá. Foram utilizados 2 métodos para a construção da metodologia deste trabalho, o macro-zoneamento utilizando um Sistema de Informação Geográfica (SIG) e o levantamento sócio- 
econômico, sendo entrevistados os lideres das comunidades que se encontravam dentro da área considerada economicamente viável para a exploração florestal no estado do Amapá. Os principais resultados deste levantamento estão concentrados na questão do apoio das instituições, governamentais e não-governamentais, para tentarem resolver, junto com as comunidades, os desafios encontrados na busca da sustentabilidade de suas famílias, para que possam assim, manter suas tradições e culturas no mesmo lugar onde viveram seus pais e avós. E no caso das comunidades formadas pela reforma agrária, os desafios são os mesmos, o apoio ainda se faz mais necessário pois na maioria dos casos as famílias podem nem possuir alguma tradição agrícola, e quanto mais florestal, para que possam transformar seus lotes em empreendimentos economicamente viáveis na Amazônia. Foram caracterizadas 56 comunidades em 8 municípios que integram a área economicamente viável para a exploração florestal, área de aproximadamente 29.838 $\mathrm{Km}^{2}$, correspondendo a $20,8 \%$ do território estadual. Todas as comunidades caracterizadas estão na área de viabilidade econômica e possuem potencial para desenvolverem o manejo florestal, mas dentre elas 8 , localizadas em somente 2 municípios, possuem serrarias já em funcionamento e poderiam ser as eleitas para o desenvolvimento de um projeto piloto de manejo florestal comunitário. As áreas identificadas como as mais viáveis para o Manejo Florestal, devem ser incorporadas pelo governo em seus zoneamentos ecológico e econômico, para que futuramente possa subsidiar com informações estratégicas o desenvolvimento do estado através de sua grande aptidão natural, a produção madeireira em regime de sustentabilidade. 


\title{
Identification and characterization of areas and communities with potential for the development of comunitary systems for forest products at Amapa State
}

\author{
Author: MAURO JOSÉ CAPÓSSOLI ARMELIN \\ Adviser: Prof. VIRGÍLIO MAURÍCIO VIANA, PhD
}

\section{SUMMARY}

There are several ways to promote the development, but rare are those that would privilege most social classes. The sustainable development is an improved concept of the development known today, that strives to accomplish not only the natural resources sustainability, but also to share the profits within all segments in the society. Today, with the predominance of this development model, the only results shared with the society are the social-environmental problems that were once created. This work's main purpose was an attempt to know better the communities from the Amapa State, and the understanding of the public politics development that this State has adopted, when it requested a survey of its own wooden sector in 1998 to "Instituto do Homem e Meio Ambiente da Amazonia" - Imazon. Two methods were used to create this work's methodology, the macro zoning that used the Geographic Information System - GIS and the social-economic survey, where some community leaders were interviewed. This survey main results are focused in helping the institutions, public or private, in trying to solve, in colaboration with these communities, the challenges found in the attempt to 
support their families and, also in order to keep their traditions and culture in its natural place. In the case of those communities created with the agrarian reform, the challenges are the same, the support is still needed because in most cases these families don't even have agricultural tradition, specially forest management, to transform their lands in economic feasible business in the Amazon region. There were characterized 56 communities in 8 cities that compound the economically feasible area for forest management, an area of approximately $29.838 \mathrm{Km}^{2}$ corresponding to $20.8 \%$ of the state territory. All characterized communities are in the economically feasible area and have the potential to develop the forest management, but among them 8 , located in only 2 cities, have sawmills already working and could be elected to the development of a pilot project for a communitary forest management. The areas identified as the most feasible for the forest management should be incorporated by the government in its ecological and economic zonings, in order to provide strategic information for the State development in the future through its huge natural aptness to the wood production in sustainability regime. 


\section{INTRODUÇÃO}

As políticas públicas devem se desenvolver dentro do contexto do máximo aproveitamento pela sociedade e que ao beneficiar um ator social não deve ser em detrimento de outro.

Essa idéia de políticas públicas justas e sustentáveis se aplica principalmente à concepção equivocada de alguns incentivos governamentais para grandes empreendimentos. Estes beneficiam o grande empreendimento e, na maioria das vezes, prejudicam boa parte da sociedade. Com esse modelo de desenvolvimento os pequenos poderão, no máximo, se "beneficiar" com uma condição de sub-emprego, acabando por nunca se desenvolver como cidadãos e profissionais.

A atividade madeireira no Estado do Amapá é bastante modesta, existindo cerca de 66 indústrias em funcionamento consumindo aproximadamente $140.000 \mathrm{~m}^{3} \mathrm{de}$ madeira em tora para produzir algo em torno de $47.000 \mathrm{~m}^{3}$ de madeira processada (Veríssimo et al., 1999).

A produção do Estado, comparada com o restante da região, é insignificante e sem destaque na economia regional, representando $0,5 \%$ da produção da Amazônia Legal (Veríssimo et al., 1999), e tendo o Estado o menor índice de áreas florestais alteradas da Amazônia brasileira conclui-se que o setor florestal, através da produção madeireira tem um grande potencial, podendo assim colaborar com o desenvolvimento da economia estadual. 
Em 1998 o IMAZON, Instituto do Homem e Meio Ambiente da Amazônia, a pedido da Secretaria de Agricultura, Pesca, Floresta e Abastecimento do Estado do Amapá, realizou o diagnostico "O setor madeireiro no Amapá", publicado em 1999 pelo governo do Estado e IMAZON, com os objetivos de traçar o perfil do setor florestal madeireiro e elaborar propostas para o desenvolvimento sustentável da atividade no Estado.

A partir das sugestões apresentadas no diagnóstico, o Governo do Estado resolveu priorizar dois estudos para promover ações de desenvolvimento do setor florestal no Estado do Amapá, estando entre eles a "Identificação de áreas e caracterização de comunidades com potencial para o desenvolvimento de sistemas comunitários e de pequena produção florestal no Estado do Amapá", sendo esta tese um componente deste estudo, que também esteve sob a responsabilidade do IMAZON.

O Manejo Florestal Comunitário (MFC) existe no Brasil, porém está ainda em estágio embrionário e com seu desenvolvimento comprometido, devido ao desconhecimento das condições para o sucesso do empreendimento e, principalmente, de seu potencial econômico e ambiental.

Soma-se a isso o problema da comercialização, onde a pequena quantidade de madeira produzida é identificada como o principal problema enfrentado nesta etapa. Muitas empresas interessadas em consumir a madeira produzida pelos projetos de MFC só conseguiriam abastecimento para apenas poucos dias de suas linhas de produção. $\mathrm{O}$ mercado está acostumado a consumir grandes quantidades e de poucas espécies, típico da exploração florestal desordenada.

O Governo do Estado do Amapá precisa promover o desenvolvimento estadual. Promover esse desenvolvimento conciliando a conservação dos recursos naturais e o envolvimento de todas as classes sociais com os modelos tradicionais de desenvolvimento é um dos problemas que o Governo do Estado está enfrentando. Nossa sugestão é promover o desenvolvimento estadual através do manejo florestal pelos cidadãos que já se encontram inseridos no contexto de produção florestal. 
Para o levantamento no Estado do Amapá foram objeto de estudo as famílias, que podem formar uma comunidade, e algumas comunidades, já formadas, que podem vir a desenvolver um projeto de manejo florestal comunitário.

Assim, o enfoque da pesquisa foi o diagnóstico socioeconômico das famílias/comunidades e seu envolvimento com a floresta, levantando dados como a renda familiar, os produtos florestais utilizados, os bens produzidos e sua participação na formação da renda, além das informações sobre a composição familiar.

\subsection{Objetivos}

a. Identificação de áreas com potencial para o desenvolvimento do manejo florestal no Estado do Amapá;

b. Identificação de ações estratégicas para implementação de projetos pilotos de manejo florestal comunitário, de acordo com a política de desenvolvimento do Governo do Estado do Amapá. 


\section{REVISÃO DE LITERATURA}

\subsection{Amazônia, Desenvolvimento e políticas públicas}

A humanidade é capaz de tornar o desenvolvimento sustentável, e para isso é necessário empenho político. Cada comunidade luta pela sobrevivência e prosperidade quase sem levar em consideração o impacto que causa sobre as demais. As falhas que precisamos corrigir vem da pobreza e do modo equivocado com que temos buscado essa prosperidade. A prosperidade alcançada em algumas partes do mundo é, na maioria das vezes, insustentável pois foi obtida através de práticas agrícolas, florestais e industriais que só resultam em lucro e progresso num curto espaço de tempo (Brundtland, 1988).

Nas esferas governamentais não existe consenso sobre o significado de desenvolvimento sustentável. Por essa razão ainda continua somente como um discurso nos fóruns internacionais, para a viabilização de recursos financeiros junto as instituições multilaterais (Diegues, 1999).

O desenvolvimento é um conceito pluridimensional, um crescimento econômico não é sinônimo de desenvolvimento. Onde há um crescimento que possui custos sociais e ecológicos extremos, é um crescimento que leva a um desenvolvimento insustentável. Não é eficiente economicamente só aquilo que traz lucro ao empresário. É eficiente economicamente aquilo que, do ponto de vista da sociedade inteira, constitui uma utilização racional dos recursos (Sachs, 1995). 
Representando metade do território nacional num país que necessita mobilizar seus recursos naturais e humanos para promover o desenvolvimento, a Amazônia é uma das regiões que possui o papel mais conflituoso neste processo de desenvolvimento em todo o Brasil (Diegues, 1999).

Os recursos ambientais são mais pressionados quando a pobreza e desemprego aumentam, cenário onde um número maior de pessoas se vê forçado a depender mais diretamente deles. Muitos governos suspenderam seus esforços para proteger o meio ambiente e para inserir considerações ambientais no planejamento do desenvolvimento (Brundtland, 1988).

É preciso apressar a substituição dos modelos preservacionistas que se baseiam nas idéias da intocabilidade dos recursos naturais e de exclusão das populações tradicionais que habitam essas áreas por modelos organizados em torno da idéia de conservação através do conceito de gestão patrimonial que abre várias possibilidades para se conciliar a preservação estrita com diversas alternativas de uso sustentável dessas áreas (Diegues, 1991).

No final da década de 90 se tornou mais evidente a crescente falta de integração entre duas estratégias estatais de desenvolvimento. Uma tendo como base o planejamento e favorecimento de novos investimentos, e abertura de mercados. Outra direcionada para o desenvolvimento sustentável, as populações tradicionais e a proteção ambiental (Becker, 1999). Estes modelos ainda coexistem, porém a falta de integração entre eles impede que a idéia do desenvolvimento sustentável seja realmente aplicada.

É um erro tentar discutir qual o melhor "desenvolvimento sustentável" para a Amazônia. O que deveria estar sendo discutido é quais os modelos ideais de "sociedades sustentáveis" mais apropriados para a Amazônia, baseados na biodiversidade socioambiental de cada região (Diegues, 1999).

Foi um erro atribuir a responsabilidade de evitar danos ambientais a ministérios e órgãos setoriais, que por fim os causavam com sua ineficiência política que não conseguia controlar a destruição causada por políticas agrícolas e industriais (Brundtland, 1988). 
A noção de desenvolvimento sustentável tem que refletir na prática, no caso da região amazônica, em modelos de ocupação sustentável de uma espaço territorial heterogêneo. Esse conceito implica na aceitação do uso dos recursos florestais para finalidades sociais e, esse modelo mais moderno de desenvolvimento necessita que as políticas públicas que podem viabilizar o uso sustentável da floresta sejam discutidas amplamente (Smeraldi et al., 1994).

As forças para o desenvolvimento nas florestas do Brasil são moldadas por diversos fatores econômicos, entre eles a distribuição muito desigual de terra e renda e significativa desigualdade entre as cinco grandes regiões do Brasil, o que influencia a taxa de migração urbano-rural e inter-regional (Lele et al., 1999).

A migração reduziu na década de 90 em relação a outras passadas, e hoje o que predomina na Amazônia é a emigração inter-regional. A importância desse movimento é confirmada, embora ainda predomine a pressão da pobreza nordestina na Amazônia Oriental. Sendo o melhor exemplo disso a migração de maranhenses para o Amapá (Becker, 1999).

Enquanto a população absoluta continua a crescer na Amazônia desde a década de 60, a taxa de crescimento diminuiu desde 1970. É flagrante que a taxa de migração para a Amazônia é maior do que para as outras regiões brasileiras (Becker, 1999). Somente em Roraima e no Amapá as taxas de crescimento aumentaram após 1980, com o crescimento populacional da região diminuindo consideravelmente de ritmo. Tocantins e Maranhão, onde a taxa de crescimento anual de 1980 a 91 era abaixo dos 2,5\% do crescimento natural, na verdade experimentaram uma migração líquida para fora do estado (Lele et al., 1999).

Os processos de migração possuem um componente espontâneo e outro dirigido pela política de reforma agrária, sendo sua aceleração uma prioridade para o governo federal. Os assentamentos na Amazônia e seu padrão migratório revela dois novos corredores de povoamento, em direção ao Amazonas e ao Amapá (Becker, 1999).

As condições de mercado enfrentadas pelos produtores amazônicos estão longe de propiciar perspectivas sustentáveis. A reduzida infra-estrutura de escoamento e armazenagem reforça o isolamento dos produtores em relação aos mercados. É 
necessário que os preços dos produtos reflitam os benefícios externos derivados da manutenção da cobertura florestal, situação propiciada pelo manejo florestal (Smeraldi et al., 1994).

\subsection{A dinâmica do desmatamento na Amazônia, o papel da agricultura e da pecuária}

Por um lado, a Floresta Amazônica é considerada a nova fronteira agrícola e a maior reserva madeireira do País. Por outro, é vista como a principal reserva florestal tropical do mundo para fins de conservação dos recursos naturais. Viabilizar economicamente a utilização da floresta, sem convertê-la em sistemas agrícolas, constitui hoje o maior desafio para as políticas de desenvolvimento (Armelin, 2000).

O modelo de crescimento da economia agrícola em áreas florestais através de posseiros que abrem as matas, estimulados por madeireiras e sua expropriação por fazendeiros de gado foi iniciado nos estados de São Paulo e Minas Gerais na década de 50, estendeu-se pelos estados de Goiás e Mato Grosso e caracterizou a ocupação da Amazônia a partir do final da década de 60 (Becker, 1999).

Os assentamentos agrícolas tem gerado resultados limitados devido a baixa fertilidade dos solos, dos preços baixos oferecidos pelo mercado, das pragas e dos sistemas de produção inadequados. Com essas dificuldades parte dos assentados acabou vendendo suas terras para fazendeiros ou especuladores e migrou para mais longe (Diegues, 1999).

Historicamente os procedimentos para a obtenção legal da terra especificavam que a única maneira de se conseguir o título da terra na Amazônia era através do desmatamento. A floresta era vista como um empecilho para a limpeza da área e obtenção do título (Veríssimo et al., 1996).

A taxa de desmatamento da Floresta Amazônica tem sido tema em vários

fóruns de discussão, regionais e internacionais. Depois de uma leve desaceleração no início da década de 90, o desmatamento voltou a crescer acentuadamente a partir de 1994 
e, com os incêndios e queimadas dos últimos anos, a pergunta de como desestimular o desmatamento na região tem surgido com mais frequência (Smith et al., 1998).

Acredita-se que a agricultura itinerante responde por cerca de um terço do desmatamento na Amazônia, enquanto a expansão e manejo de pastagens para o gado é responsável por pelo menos a metade do desmatamento ocorrido na segunda metade da década de 90 (Serrão et al., 1996).

As antigas práticas agrícolas tinham no sistema de corte e queima uma alternativa para o cultivo em solos de baixa fertilidade e ácidos que dominam grande parte da Amazônia, porém a fertilidade alcançada com a queima da floresta é temporária, onde a infestação das áreas agrícolas reduz ainda mais a produtividade (Nepstad et al., 1999).

A produtividade diminui sensivelmente entre um e três anos após a derrubada e queima da floresta, forçando assim a abertura de novas áreas agrícolas, substituindo a floresta, a cada novo ano na tentativa de manter o padrão de rendimento e subsistência familiar (Nepstad et al., 1999).

Mais de 5 milhões de pessoas dependem da agricultura de subsistência na Amazônia brasileira. As populações rurais na Amazônia oriental, em várias partes, são agora abundantes inviabilizando assim a prática da agricultura de corte e queima, e também diminuindo os períodos de pousio entre os ciclos de cultivo, impossibilitando a recuperação dos solos e com isso impondo o desafio de como intensificar a agricultura e, ao mesmo tempo, manter os solos em boas condições físico-químicas (Toniolo e Uhl, 1996).

Em algumas regiões da Amazônia, como a região de Tomé-Açú (PA) colonizada na década de 20 por japoneses, a agricultura intensiva tem mostrado excelentes resultados em áreas previamente desmatadas e com solos de baixa fertilidade natural. Nessa região os agricultores tem obtido sucesso com o cultivo de culturas perenes como pimenta-do-reino, cacau, acerola, maracujá, laranja e manga, devido a possibilidade de reciclagem de nutrientes no sistema solo-planta (Toniolo e Uhl, 1996).

Embora a intensificação da agricultura seja economicamente inviável na Amazônia em determinado lugar no tempo, isso pode mudar de acordo com a dinâmica 
de desmatamento e urbanização da área. Depois de retirada a floresta, normalmente pelos madeireiros, a terra passa a ser alvo da especulação imobiliária, ciclo que começa com os colonos em busca de terra barata para o cultivo, estabelecendo pastagens em áreas de pousio para agregar valor a terra, e termina com a venda da propriedade pela melhor oferta encontrada para fazendeiros vizinhos, e com isso a mudança para novas fronteiras (Toniolo e Uhl, 1996), recomeçando assim o ciclo de desmatamento e ocupação humana desordenada.

As florestas também são derrubadas e queimadas para a formação de pastagens. Raramente as pastagens são formadas sem a queima da floresta, já que as cinzas geradas são vitais, nos processos químicos da fertilidade do solo, para a formação da pastagem. Além disso, o fogo é a forma mais barata de limpar a área para o plantio da pastagem (Nepstad et al., 1999).

Aproximadamente $10 \%$ da área florestal da Amazônia oriental foram convertidos em pastagens durante o período de 1960 a 1990. Durante este período o desempenho econômico da pecuária foi fraco, mas a mudança dos sistemas de criação de gado onde alguns pecuaristas se especializaram na produção de bezerros, na engorda de animais ou na pecuária leiteira tem viabilizado economicamente a atividade, pelo menos no prazo mais imediato. Ainda permanece a dúvida a respeito da sustentabilidade da pecuária na Amazônia (Mattos e Uhl, 1996).

A Amazônia é uma das áreas do mundo com a mais alta probabilidade de abrigar um predador natural para qualquer cultura agrícola introduzida pelo homem. Além disso, as modificações no ambiente para controlar uma praga particular possuem uma alta probabilidade de tornar a cultura vulnerável a outras pragas (Scheneider, 2000).

Atualmente cerca de 25 a 50\% das pastagens originais na Amazônia oriental estão degradadas e/ou abandonadas. Cientistas políticos, economistas e ecologistas tem criticado a conversão de florestas em pastagens, argumentando que a criação de gado tem mais motivação vinda da especulação do que na produção de carne e leite. As análises econômicas do sistema mostraram que a pecuária não conseguiria se manter sem os enormes subsídios recebidos, ou que só seria lucrativa se fosse praticada de forma 
itinerante, utilizando o sobrepastejo e investindo na especulação de terras (Mattos e Uhl, 1996), tornando a atividade ainda mais impactante.

\subsection{Manejo florestal e extrativismo na Amazônia}

Existem várias dúvidas sobre se o desenvolvimento da Amazônia passa pela agricultura, mas nenhuma dúvida da importância do manejo florestal como vetor do desenvolvimento. De acordo com o relatório "Amazônia sustentável: limitantes e oportunidades para o desenvolvimento rural" editado pelo Banco Mundial e Imazon em 2000, a agricultura vem colecionando uma série de fracassos históricos, que podem ser muito instrutivos para não tentar repetir no Amapá o mesmo modelo equivocado de desenvolvimento.

Quando florestas são convertidas em sistemas agrícolas, como a pastagem, cerca de 170 toneladas de carbono por hectare são liberados para a atmosfera durante a queima e decomposição da matéria orgânica para a limpeza da área (Mattos e Uhl, 1996). A emissão de carbono para a atmosfera é apontado pelos cientistas como o principal causador do aquecimento global e conseqüentemente das mudanças climáticas.

Cerca de 20 a 25 milhões de $\mathrm{m}^{3}$ de madeira em tora são extraídos anualmente na Amazônia, atingindo uma área de 8 a $10 \mathrm{mil} \mathrm{km}^{2}$ de florestas. A maior parte da exploração ocorre ao longo de um arco ao sul da bacia amazônica que vai do leste do Acre, passando por Rondônia e norte do Mato Grosso, até o centro-sul do Pará. Se manejada adequadamente a atividade madeireira poderia ser uma fonte de riqueza para a região (Smeraldi et al., 1998).

A região amazônica se caracteriza por sua diversidade. Convivem, em conflito ou harmonia, populações indígenas com seringueiros, colonos transplantados do sul ou nordeste com ribeirinhos, mega-empreendimentos agrícolas com a produção familiar

pouco significativa para o mercado, e o extrativismo praticado a séculos na região (Allegretti em Becker, 1999).

Com a exaustão das florestas da Ásia, responsável por grande parte da oferta de madeira tropical para o mercado internacional o Brasil, que possui cerca de um terço das 
florestas tropicais do mundo, possui uma oportunidade de desenvolver a região amazônica através do manejo florestal, dominando o mercado neste século (Veríssimo et al., 1996; Smeraldi et al. 1998).

A pecuária continuará a substituir florestas na Amazônia se o manejo florestal não se mostrar mais competitivo. Existem evidências de que o manejo florestal se tornará cada vez mais atrativo a medida que os produtos não madeireiros, como sementes, frutas e óleos, entrarem no mercado (Mattos e Uhl, 1996), tornando assim a conservação da floresta mais competitiva quando comparada aos sistema agrícolas, pecuários e a extração ilegal de madeira, que possuem rápido retorno econômico.

Este debate chegou também a floresta, e a principal questão levantada é quem deve manejá-la. Os grandes empreendedores, que sem sombra de dúvida ocupam um importante papel em nossa sociedade ou os pequenos proprietários e moradores da floresta, dando assim a oportunidade dos benefícios gerados pela cadeia produtiva ser dividido entre o bolo social.

Uma das propostas para a promoção do manejo florestal sustentável e a conservação dos recursos naturais na Amazônia é a criação de Reservas Extrativistas, onde a população que habita a região se encarregaria de tornar a floresta produtiva. Essa proposta também é única no sentido de combinar objetivos de justiça social, desenvolvimento sócio-econômico, manejo sustentável e proteção da Amazônia (Diegues, 1999).

O extrativismo é iniciado quando o recurso deixa de ser um bem livre, com o crescimento da demanda. O fim do extrativismo se dá quando existe o esgotamento dos recursos extrativos ou quando sua oferta se estagna e não acompanha a demanda (Homma, 1992).

O sucesso econômico de uma reserva extrativista dependerá da habilidade de seus manejadores na adoção de estratégias contra a variação brusca dos preços dos produtos. Neste caso a diversificação é uma estratégia comum adotada no mercado financeiro que deve também ser adotada em uma operação extrativista, mas esta só é possível caso os recursos utilizados o sejam de maneira sustentável. (Arima, 1998). 
Outra característica do extrativismo é sua dependência do setor agrícola, de onde provem os alimentos necessários a subsistência e sua intermediação com o setor comercial que adquire o produto extrativo. Historicamente a exploração dos seringais na Amazônia foi garantida pela transferência de alimentos produzidos na região Bragantina, no estado do Pará (Homma, 1992).

O sucesso de uma reserva extrativista depende da administração adotada, onde organização social, uso sustentável dos recursos, diversificação e qualidade de produto possuem papel determinante. Assim, o apoio de organizações, sejam governamentais ou não, a estas iniciativas são fundamentais (Arima, 1998).

O atual processo de desenvolvimento da várzea está levando à degradação dos seus ecossistemas. A várzea tem seus recursos, ao mesmo tempo, sub-utilizados pois os sistemas atuais de exploração aproveitam somente uma fração do potencial produtivo, e superexplorados pois esses sistemas de exploração estão esgotando os recursos que são utilizados, contribuindo assim para a degradação dos ecossistemas de várzea como um todo (Smeraldi, 1997).

Mesmo com seu potencial, a agricultura da várzea continua em crise e sem alternativas seguras para resolver os problemas de baixa rentabilidade, degradação ecológica e ausência de mercados para a pequena produção. Embora vista como o ambiente mais adequado para a pequena produção intensiva, a evolução do uso do solo da várzea segue as mesmas tendências que dominam a terra firme, a expansão da pecuária e das culturas extensivas (Smeraldi 1998). Por outro lado a criação de reservas extrativistas nas várzeas da Amazônia seria um exemplo de desenvolvimento econômico aliado a igualdade de distribuição de renda, onde a conservação funcionaria como uma estratégia econômica (Arima, 1998).

A discussão sobre o grande produtor versus o pequeno na Amazônia se concentra muitas vezes ao redor da comparação entre os pontos negativos de cada um, onde o grande, para satisfazer suas necessidades de máximos lucros usa intensamente os recursos naturais, e o pequeno não. Essa discussão é infrutífera se for conduzida desta maneira, mas pode esclarecer que é pesada demais a responsabilidade que é depositada 
sobre o pequeno produtor de produzir eternamente sem esgotar os recursos naturais (Nitsch \& Kasper, 1998).

\subsection{Espaço comum e comunidades tradicionais}

As mais importantes ameaças a sustentabilidade dos recursos naturais são os conflitos relativos ao acesso e ao uso não destrutivo e sustentável da natureza. Tais conflitos ameaçam a biodiversidade e também a existência e continuidade das comunidades, que além de dependerem do uso sustentável dos recursos prestam um serviço a sociedade, desempenhando um papel ativo na conservação da natureza (Hall, 1997).

A idéia de comunidade é freqüentemente associada a uma configuração espacial física. É o bairro, o povoado, os moradores de uma bacia ou ribeirinhos. Essa visão de comunidade, que ignora as diferentes relações sociais existentes não é a ideal quando o objetivo é a promoção do desenvolvimento (Leroy, 1997). No Brasil o sucesso do termo comunidade se deve muito à Igreja Católica progressista, onde na Amazônia, o termo chega a substituir o de aldeia, de povoado e acaba por nomear qualquer coletividade local (Lená, 1997).

As comunidades locais constituem os principais alvos das propostas de desenvolvimento (Becker, 1997). Depois de várias tentativas de desenvolvimento comunitário promovidos por agências estatais como Sudam e Sudene na década de setenta, e as comunidades eclesiais de base na década de oitenta o conceito de comunidade parece bem difundido entre a sociedade, porém ainda de difícil conceituação (Leroy, 1997).

Um aspecto importante na definição de comunidades tradicionais é a existência de formas de manejo dos recursos naturais determinados pelo respeito aos ciclos naturais, nunca explorando os recursos além do limite da capacidade de sua recuperação natural. Essas formas de exploração se revelam não somente economicamente viáveis, mas principalmente detentora de conhecimentos herdados pelos comunitários de seus antepassados (Diegues, 1994 a). 
A identidade da comunidade é autoconstruída e seus membros podem ou não concordar com as mesmas idéias, compartilhar da mesma situação financeira e participarem da mesma classe social, porém a não aceitação da existência de lutas de classe pode ser uma forma de afirmar o compromisso com um destino comum através da formação de grupos coesos em debates, proposições e ações para o desenvolvimento comunitário (Leroy, 1997).

As comunidades tradicionais se caracterizam por possuírem um tipo de organização econômica e social com pouca ou nenhuma acumulação de capital, não usando assalariados para sua produção. Uma das características mais importantes desse modelo de produção é o conhecimento que as famílias possuem a respeito dos ciclos naturais e de como manejá-los, sendo esse um importante instrumento para a conservação dos recursos naturais já que a sustentabilidade deste modo de vida é completamente dependente dos recursos naturais. Nesta sociedade a conservação dos recursos naturais é um fator cultural (Diegues, 1994 b).

Uma comunidade pode ser considerada tradicional quando se caracteriza pela:

- dependência da natureza, dos ciclos naturais dos recursos naturais renováveis a partir do qual constroem seu modo de vida;

- conhecimento aprofundado da natureza e de seus ciclos, transferidos para as gerações seguintes;

- noção de território onde a comunidade se reproduz econômica e socialmente;

- ocupação deste território por várias gerações;

- importância das atividades de subsistência, mesmo que esta gere algumas

"mercadorias" e contato com o "mercado";

- reduzida acumulação de capital;

- importância da unidade familiar, doméstica ou comunal;

- importância das simbologias;

- utilização de tecnologias simples e de baixo impacto sobre o meio ambiente;

- fraco poder político; 
- auto-identificação, ou identificação feita por outros, com uma cultura distinta das outras (Diegues, 1994 b).

Outro importante elemento na relação entre comunidades tradicionais é a idéia formada a respeito do que é "área comum". Este espaço em comum é definido por Diegues, 1994, baseado em Godelier, 1984, como "...uma porção da natureza e espaço sobre o qual uma sociedade determinada reivindica e garante a todos, ou a uma parte de seus membros, direitos estáveis de acesso, controle ou uso sobre a totalidade ou parte dos recursos naturais ali existentes que ela deseja ou é capaz de utilizar".

Ao discutir sobre o conceito de comunidade a também de se discorrer sobre território, onde a convivência permite o conhecimento mútuo e possibilita a ação conjunta (Leroy, 1997). O território não depende somente de seus limites e do que nele é explorado, existe uma série de relações sociais que determina seu tamanho e forma de utilização. Nas comunidades tradicionais o território tem dimensões definidas através da agricultura itinerante e pelo respeito ao território que outro comunitário utiliza através do extrativismo vegetal (Diegues, 1994 a).

\subsection{Manejo Florestal Comunitário}

Existe hoje na Amazônia 14 iniciativas de manejo florestal comunitário. O sucesso dessas iniciativas depende principalmente de:

- da continuidade dos investimentos;

- da capacidade gerencial das comunidades;

- da formação e capacitação de mão-de-obra para as atividades;

- do entendimento do manejo florestal comunitário através de aspectos sociais e econômicos, além dos técnicos;

- legalização fundiária (Amaral, 1998).

Hoje, depois de algumas iniciativas já completarem 4 anos de funcionamento, recebido, em média, 4 financiamentos a fundo perdido e a legislação específica para o MFC já existir, nota-se que a viabilização do manejo florestal comunitário depende ainda de vários outros fatores que não somente os listados acima. 
Em vários países e estados com recursos florestais está havendo uma notória redução das áreas cobertas com florestas, e este evento se deve a dois principais problemas. Um deles é a situação econômica que obriga as comunidades a buscarem resposta a suas necessidades econômicas através da exploração florestal completamente desordenada, e outra é a lei agrária que permite o desmatamento de parte das áreas destinadas a reforma agrária (Suárez, 1995).

Nestes dois casos, apontados acima, as comunidades são protagonistas da redução da área florestal, isso se deve a falta de perspectiva de manejarem a floresta a longo prazo, devido aos impedimentos técnicos e econômicos que possuem (Suárez, 1995).

O sucesso do manejo florestal realizado em pequenas propriedades depende da participação direta do proprietário nas atividades de extração e comercialização dos produtos florestais, do conhecimento das técnicas e métodos a serem empregados (Araújo, 1999).

$\mathrm{Na}$ Amazônia os pequenos proprietários, ao desenvolverem o manejo florestal em regime de sustentabilidade em suas propriedades, podem desempenhar um importante papel na conservação dos recursos florestais. Através deste tipo de manejo florestal é possível diversificar as fontes de renda, conferindo também as floresta algum valor econômico, tornando assim o manejo florestal uma atividades econômica potencialmente mais atrativa para o pequeno proprietário rural do que a pecuária e a agricultura convencional (Armelin, 2000).

Vários projetos de manejo florestal comunitário estão sendo desenvolvidos na Amazônia e, mesmo este modelo sendo tecnicamente viável de acordo com essas experiências, o MFC ainda não saiu do plano piloto. Isso pode ser explicado quando se toma conhecimento das várias áreas do saber envolvidas no processo (Araújo, 1999).

\subsection{Produção florestal e desenvolvimento no estado do Amapá}

O estado do Amapá hoje possui uma posição privilegiada. É o estado com a menor área de floresta amazônica alterada, 99\% de sua cobertura vegetal original 
(Veríssimo et al., 1999) com uma área alterada, que inclui desmatamentos e outras formas de antropização, de 2.795,5 $\mathrm{Km}^{2}$, ou 1,9\% do seu território (Amapá, 1999). E pode, ainda, escolher os sistemas de exploração florestal que podem gerar o desenvolvimento estadual, a comunitária e empresarial.

Através de políticas públicas bem planejadas, as formas de desenvolvimento, citadas acima, baseadas na produção florestal, podem e devem ser complementares, ao contrário do que normalmente ocorre, onde uma pode excluir a outra. Quando isso acontece a sociedade é quem perde. Para o estado do Amapá, áreas deveriam ser destinadas ao manejo florestal em pequena escala e também para o manejo realizado pelas grandes empresas, onde as iniciativas poderiam ser complementares de acordo com a estratégia de produção adotada pelo governo.

O manejo florestal e a industrialização da biomassa é uma alternativa das mais promissoras para o desenvolvimento do Amapá. Assim torna-se urgente o investimento na elaboração de modelos de gestão florestal que garantam a sustentabilidade ecológica do manejo e consiga viabilizar um pólo local para a transformação e agregação de valor desses recursos (Castro, 1998).

Segundo o Plano Estadual Ambiental, elaborado em setembro de 1997, a agricultura do Estado, apesar de indícios que apontam que a produção tende a aumentar, as limitações de ordem física e de infra-estrutura prejudicam sensivelmente o processo produtivo. A pecuária extensiva da Planície Flúvio Marinha do Amapá, onde as pastagens naturais são abundantes acaba por provocar danos ambientais, que acompanham a bubalinocultura, como a poluição dos mananciais de água doce, a compactação do leito dos lagos e pequenos rios, a afugentamento e a mortandade dos peixes, resultando num grande impacto ambiental que representa um custo muito alto para os insignificantes benefícios que gera para o Estado (Castro, 1998).

Este Plano aponta, também, a mineração como uma grande causadora de sérios problemas sócio-ambientais e econômicos, que vão desde a descaracterização da paisagem até a evasão de tributos. Por outro lado, aponta a atividade extrativa de produtos madeireiros e não-madeireiros como uma importante alternativa de desenvolvimento para o estado, colocando a indústria do mobiliário como um 
importante setor dentre as industrias de transformação por concentrar grande parte dos estabelecimentos comerciais, gerando assim muitos postos de trabalho.

\subsection{Caracterização do Estado do Amapá}

\subsubsection{Localização}

Situado no extremo norte do pais, o Estado do Amapá tem uma superfície territorial de $140.276 \mathrm{Km}^{2}$, que corresponde a 1,6\% do Brasil e a 3,6\% da Região Norte. Faz fronteira com o Estado do Pará, Suriname e Guiana Francesa. Relativamente pequeno, se comparado com outros Estados da Amazônia, o Amapá concentra uma grande diversidade em ambientes naturais, já que faz parte de dois domínios geográficos: o amazônico e o oceânico (Amapá, 2000).

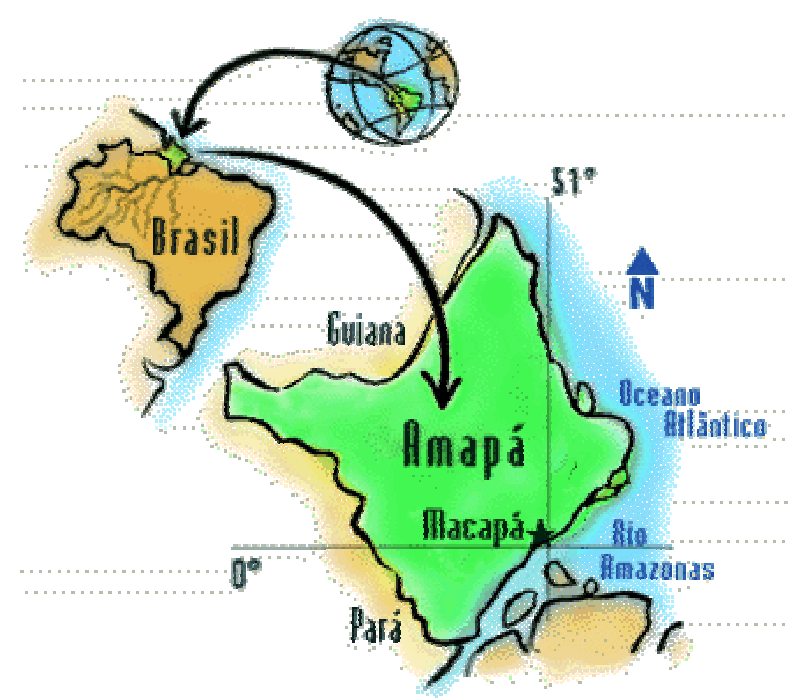

Figura 1 - Localização geográfica do Estado do Amapá 


\subsubsection{Divisões fisiográficas}

O Estado é dividido em duas grandes regiões: uma interna, de relevo suavemente ondulado, com alturas médias de 100 a 200 metros, mas que podem atingir até 500 metros, constituída por rochas cristalinas metamórficas e cobertas de floresta densa, e outra região costeira de planície que se estende até o Atlântico, ao leste e até o rio Amazonas, ao sul (Amapá, 2000).

A cobertura vegetal do Estado apresenta-se em dois padrões principais: as formações florestais, com florestas densas de terra firme, florestas de várzea e manguezais e formações campestres, com cerrados e campos de várzea inundáveis ou aluviais (Amapá, 2000).

A floresta de terra firme é o ecossistema de maior representatividade, ocupando mais de $70 \%$ da superfície do Estado. É o ambiente com maior biodiversidade e biomassa, abrigando essências de grande valor madeireiro, oleaginoso, resinífero, aromatizantes, corante, frutífero e medicinal. Constitui um dos principais potenciais produtivos do Estado (Amapá, 2000).

A floresta de várzea caracteriza todo a área de influência fluvial, representando o ambiente típico da bacia Amazônica, inclusive em termos de ocupação econômica por populações ribeirinhas. Predominam espécies de alto valor produtivo e importância sócio-econômica como o açaizeiro, andiroba, seringueira, virola, pau-mulato entre outras (Amapá, 2000).

Os manguezais formam um ecossistema bem delimitado ao longo da região costeira, diretamente influenciado pela hidrodinâmica do Rio Amazonas, apresentando alta produtividade primária e significativa riqueza e diversidade de estoques de fauna, estuarinos e oceânicos (Amapá, 2000).

O cerrado ocupa a faixa de domínio geológico da formação barreiras e biogeograficamente representa um enclave do ambiente típico do Brasil Central, apresentando espécies endêmicas e grande intervenção antrópica por estarem localizados nesses ecossistemas os principais cultivos florestais homogêneos (Amapá, 2000). 
O campo de várzea é um ambiente largamente distribuído no Estado, de natureza aluvional e submetido a regimes flúvio-pluviais ligados a um complexo sistema de drenagem que envolve cursos d'água, lagos temporários e permanentes (Amapá, 2000).

\subsubsection{Recursos naturais}

A área alterada do Estado do Amapá que inclui desmatamentos e outras formas de antropização, é de somente $2.795,5 \mathrm{Km}^{2}$, ou $1,9 \%$ do seu território de acordo com os dados do Zoneamento Ecológico Econômico de 1998. A concentração da população no eixo da única rodovia parcialmente asfaltada, que liga o Estado de norte a sul, a BR 156, com ramificações pouco impactantes, tem assegurado a existência de grandes áreas contínuas com cobertura vegetal não alterada por ações antrópicas. Inúmeras cachoeiras situadas nas diferentes bacias hidrográficas, também impediram a exploração do interior do Estado (Amapá, 2000).

A diversidade de ecossistemas caracteriza a biogeografia do Amapá, ao lado do significativo capital de recursos naturais, cujo potencial para exploração sustentável depende de alocação de tecnologia e sistemas adequados de manejo e administração. A ocupação do Estado também está marcada pela exploração de seu potencial mineral, principalmente do manganês, descoberto na Serra do Navio, exploração feita por concessão desde a década de 50, recurso hoje exaurido (Amapá, 2000).

O Amapá apresenta um conjunto significativo de áreas protegidas e reservas indígenas, abrangendo mais de $40.000 \mathrm{Km}^{2}$ e correspondendo a cerca de $30 \%$ da superfície total do Estado, 4 vezes mais que a média nacional e o dobro da média da Região Norte (Amapá, 2000). 


\subsubsection{Clima}

O clima dominante é tropical úmido, com poucas variações de temperatura, sendo outubro o mês mais quente e, de fevereiro a abril, o período mais frio. As chuvas se estendem por um longo período, de dezembro a julho, com altos índices pluviométricos, que podem chegar a $500 \mathrm{~mm}^{3}$ por mês. O período seco entre agosto e novembro, é mais curto e a precipitação diminui para menos de $50 \mathrm{~mm}^{3}$ por mês (Amapá, 2000).

\subsubsection{Vias de transporte}

Em relação a disponibilidade de vias de comunicação, a faixa litorânea é, sem dúvida, a região mais desenvolvida. Contudo, vias asfaltadas existem apenas por $160 \mathrm{Km}$, na estrada que une Macapá a Ferreira Gomes, parte da BR 156 a 21 Km no sentido oeste, na estrada que vai de Macapá em direção a Laranjal do Jarí. As principais cidades da região se comunicam por estradas de terra. Muitas localidades, com importantes recursos econômicos (pesqueiros e florestais), somente possuem comunicação marítima ou fluvial (Amapá, 2000).

\subsubsection{População}

Entre 1991 e 1996 o Amapá teve crescimento populacional de 5,3\% ao ano, passando de 289.000 para 430.000 pessoas. De acordo com o IBGE, mais da metade deste crescimento decorre de migração proveniente, principalmente, do Pará, Maranhão e Ceará (Amapá, 2000).

A criação do Estado do Amapá, com a Constituição de 1988, e da Área de Livre Comércio de Macapá e Santana (ALCMS), em 1991, transformaram o Estado em novo pólo de migração na Amazônia. Apesar disso, a densidade populacional ainda é uma das 
menores do Brasil, com uma média de 2,3 habitantes por $\mathrm{Km}^{2}$, já que a maioria da população está concentrada na capital e no município de Santana (Amapá, 2000).

Com formação étnica diversificada, existem no Amapá grupos de origem afroamericana e indígenas. As sociedades indígenas pertencem a seis etnias, distribuídas em três municípios - Oiapoque, Amaparí e Laranjal do Jarí, com total de 5.200 pessoas. Estão divididas em cinco grandes áreas sob jurisdição da Fundação Nacional do Índio (FUNAI) e tem seus territórios demarcados e homologados, representando cerca de $11 \%$ da área total do Estado. Somadas as unidades de conservação e as reservas indígenas, cerca de 30\% do território do Amapá encontra-se sobre proteção especial (Amapá, 2000).

\subsubsection{Economia}

De acordo com a SUDAM (1998), o Amapá teve entre 1990 e 1996, uma taxa média anual de crescimento econômico de 4,4\%, sendo este mais acentuado entre 199596. O crescimento foi superior à média nacional de 3,1\%, mas inferior ao crescimento populacional estadual de 5,3\% (Governo do Estado do Amapá, 2000).

A economia do Amapá é dependente dos recursos naturais caracterizando-se como exportadora de matérias-primas, produtos primários e semi-elaborados. Terminada a exploração de manganês na Serra do Navio, o cavaco de pinus, produzido pela International Paper, representa mais de 50\% da exportação total, seguido em importância pelo palmito de açaí e o pescado (Amapá, 2000).

O setor primário é caracterizado por um contingente populacional reduzido, baixo nível tecnológico e crédito restrito. O extrativismo vegetal (castanha, borracha, açaí e cacau), encontra-se em expansão em função do apoio de políticas governamentais (Amapá, 2000).

O setor secundário está concentrado nas atividades do extrativismo mineral, construção civil e indústria de transformação e tem sua capacidade de expansão limitada pela oferta de energia e outras deficiências em infra-estrutura. Excluindo-se algumas grandes empresas, predominam a informalidade e o baixo nível de utilização tecnológica (Amapá, 2000). 
O setor público é o mais representativo da economia, apesar de não ser o principal empregador. As atividade de comércio e serviços tem superado a administração pública na geração de empregos. Em 1995 das 102.445 pessoas acima de 10 anos ocupadas em algum tipo de trabalho, 20\% trabalhavam na administração pública, $21 \%$ na prestação de serviços e 19\% no comércio de mercadorias em geral (Amapá, 2000).

A Área de Livre Comércio de Macapá e Santana (ACLMS) apresenta vantagens fiscais exclusivas para consumo e venda interna na área especial, atuando nos setores do comércio, indústria de transformação, agropecuária, piscicultura, turismo e serviços (Amapá, 2000).

\subsubsection{Energia}

A empresa estatal federal Eletronorte administra um sistema de geração de energia hidrotérmica com predominância termoelétrica, correspondendo a cerca de $75 \%$ da potência instalada. Em decorrência disso, os custos da energia para o consumidor são muito altos, superando a média nacional, baseado em geração hidráulica (Amapá, 2000).

A energia hidráulica é produzida na única usina hidrelétrica do Estado, a Coaracy Nunes, com capacidade de $40 \mathrm{MW}$, situada a 130Km de Macapá, em operação desde de 1975. A usina termoelétrica de Santana teve sua capacidade ampliada em 1998 para $105 \mathrm{MW}$, criando algum excedente que será incrementado quando acontecer a instalação da terceira turbina na usina hidrelétrica (Amapá, 2000).

Macapá consome cerca de $72 \%$ da energia gerada e Santana 18\%. A classe de consumo mais representativa é a residencial, utilizando quase metade da energia gerada, enquanto as atividades comerciais consumiram 17\% e 13\%, respectivamente. Nos últimos três anos, o consumo de energia aumentou em $70 \%$, tendo contribuído para esse índice, o atendimento de diversas comunidades do meio rural e da periferia da capital do Estado (Amapá, 2000). 
Tabela 1. Dados gerais do Estado do Amapá

\begin{tabular}{ll}
\hline Capital & Macapá \\
Área & $143.453,7 \mathrm{~km}^{2}$ \\
Municípios & 16 \\
Localização & extremo norte do País \\
População & 434.781 habitantes \\
População da capital & 256.033 habitantes \\
Clima & equatorial \\
Temperatura média anual (capital) & 270 C \\
Horário em relação à Brasília & o mesmo \\
Densidade demográfica & 3,77 hab/km² \\
Índice de urbanização & 80,90 \\
Mortalidade infantil & 36,5 por mil nascidos vivos \\
Índice de analfabetismo & 16,92 \\
Participação no PIB & $0,09 \%$ \\
Representação no Congresso & 3 senadores e 8 deputados federais \\
Nacional & \\
Vegetação & Floresta Amazônica, mangues litorâneos e \\
Informações turísticas & campos gerais \\
& Departamento Estadual de Turismo - Detur \\
& Tel: (96) 223-0627 \\
& Fax: (96) 223-0567 \\
& $68906-020$ Macapá - AP \\
\hline Fonte: Amapá, &
\end{tabular}

Fonte: Amapá, 2000. 


\section{MATERIAL E MÉTODOS}

O método aplicado no levantamento é o resultado da integração de dois outros métodos que podem ser complementares: a) macro-zoneamento com utilização de Sistema de Informação Geográfica (SIG) e b) levantamento sócio-ecônomico, através de entrevistas, nas comunidades localizadas dentro das áreas determinadas pelo macrozoneamento como sendo as que possuem o maior potencial para as atividades florestais.

A utilização do SIG é fundamental, pois permite, depois de identificadas as necessidades do trabalho, excluir as áreas que não atendam aos pré-requisitos necessários para a execução da atividade principal, direcionando assim o esforço de pesquisa para as áreas consideradas potenciais para o desenvolvimento das atividades, sendo neste caso o manejo florestal. Esse processo é conhecido como geo-exclusão.

A identificação das áreas para o manejo florestal seguiu três etapas (Figura 2):

a. macrozoneamento através de Sistema de Informação Geográfica (SIG), para a identificação das áreas potenciais para as atividades florestais através do cruzamento das seguintes informações: existência de serrarias, recursos madeireiros na área, infraestrutura disponível e localização das unidades de conservação;

b. entrevistas com técnicos dos órgãos de extensão agrícola e de saúde que atuam no Estado, como RURAP, SEAF, CNPT/IBAMA e FNS (item 3.2.2);

c. levantamento sócio-econômico nas comunidades selecionadas (Anexo A4 e A5). 


\subsection{Critérios para priorização de comunidades}

Consideramos que para o Manejo Florestal Comunitário -MFC- obter sucesso é necessária a existência de algumas condições básicas para a sustentabilidade do sistema. Estas condições são as seguintes:

a) área florestada com espécies valorizadas pelo mercado;

b) existência de organização social. Neste caso a pré-existência de alguma forma de organização social indica que a comunidade tem potencial para se organizar também em torno da produção florestal para a organização e gerência do empreendimento;

c) disponibilidade de mão-de-obra para as operações do MFC;

d) situação fundiária legal ou em processo de legalização;

e) acesso ao mercado consumidor e aos potenciais. Neste ponto a já existência de operações comerciais pode indicar que aquela região está dentro da área de viabilidade econômica para os tipos de produtos que oferecem;

f) interesse da população local no desenvolvimento do manejo florestal. 


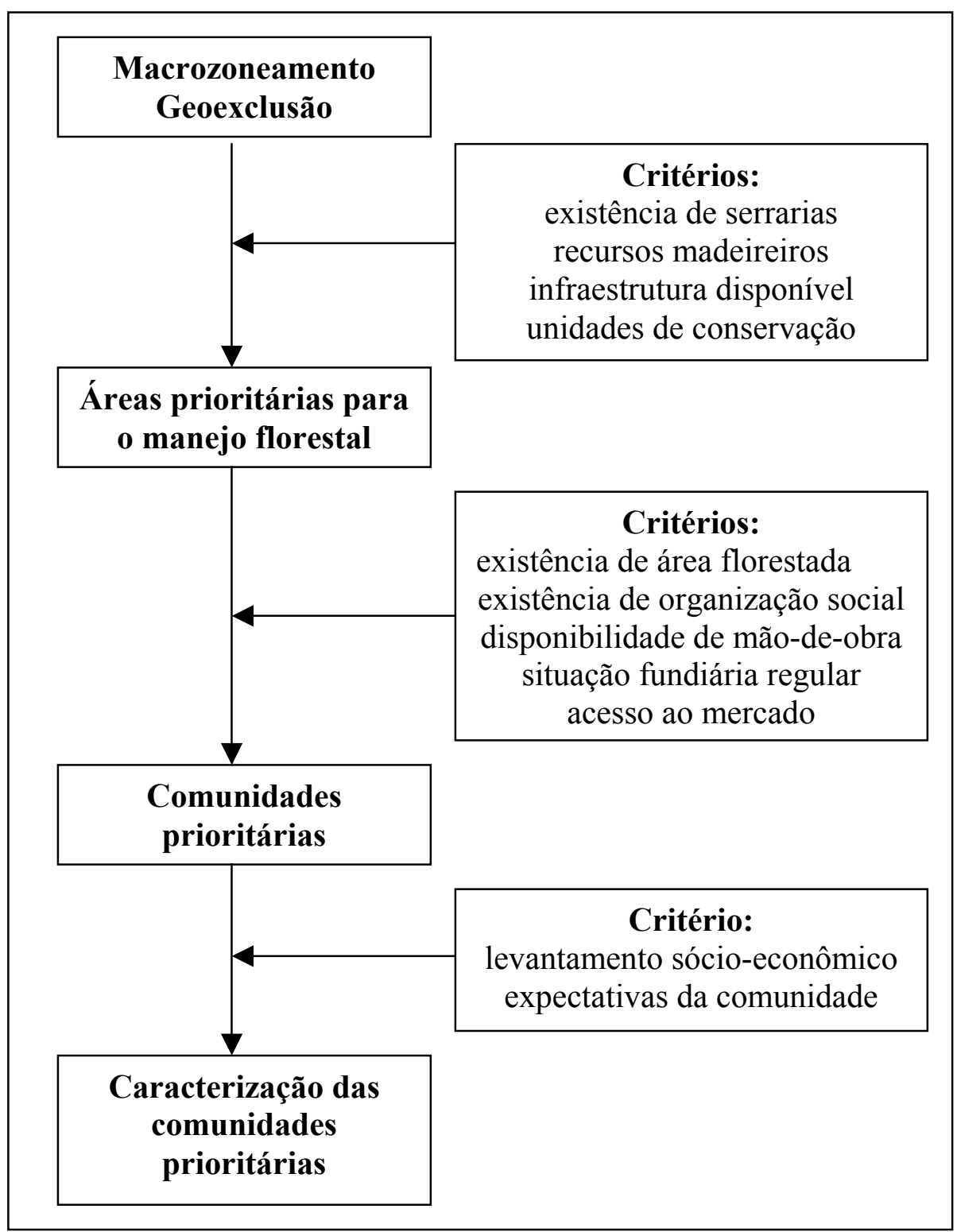

Figura 2 - Fluxograma do método aplicado. 


\subsection{Macrozoneamento}

Para identificar as áreas com maior potencial para o desenvolvimento das atividades florestais no Estado do Amapá analisamos as informações espaciais em três escalas diferentes, Estadual, Municipal e Regional. Essas informações foram cruzadas obedecendo a critérios de seleção, descritos nos itens abaixo. Estes critérios possuem caráter eliminatório e classificatório de acordo com a importância a eles atribuída, indicando as áreas onde as chances de sucesso do empreendimento florestal poderão ser maiores.

O levantamento se concentrou nas regiões sul e sudeste do Estado, por estas apresentarem a maior concentração populacional e também pela formação florestal que possuem, sendo estes dois importantes componentes para o sucesso do empreendimento florestal. Coincidentemente essas regiões também são as consideradas como prioritárias para o governo do Estado, que através do Plano para o Desenvolvimento Sustentável do Amapá (PDSA) as denominou áreas prioritárias 1, 3 e 4.

\subsubsection{A Escala Estadual}

Nesta escala foram identificadas certas particularidades que poderiam eliminar

algumas áreas do Estado que possuem características onde, legalmente ou economicamente, as atividades não poderiam se desenvolver ou seriam economicamente inviáveis. Estas características foram separadas em 3 diferentes mapas, que são:

a) Vegetação: áreas com florestas ombrofilas (densas e abertas) e estacionais como de potencial madeireiro, dados do IBGE de 1997 (Figura 3);

b) Áreas protegidas: unidades de conservação de uso indireto e as de uso direto em que a atividade madeireira são proibidas (Figura 4);

c) Alcance econômico: mapa que aponta as áreas onde a atividade madeireira no Estado do Amapá é economicamente viável (Figura 5). Extraído do estudo de 
Veríssimo et al. "1, que classifica as atividades madeireiras no Estado, considerando os grandes pólos madeireiros em Macapá e em regiões do Pará, em:

i. áreas em que a atividades madeireira é economicamente inviável;

ii. áreas em que a atividade é viável apenas para espécies de alto valor econômico;

iii. áreas em que a exploração é viável para todas as espécies comerciais;

iv. áreas em que não haverá atividade florestal madeireira por limitações naturais, como relevo e inexistência de florestas.

Foram consideradas favoráveis para o manejo as áreas onde é economicamente viável a extração de todas as espécies de valor comercial, sendo essas áreas as mais acessíveis, já que o custo do transporte é um dos indicadores mais importantes dos utilizados para a determinação da viabilidade econômica. Nos próximos anos haverá um aumento do número de espécies utilizadas, principalmente devido ao nível de consciência que o consumidor de madeira vem adquirindo.

\footnotetext{
${ }^{1}$ ALCANCE DA ATIVIDADE MADEIREIRA, neste estudo foram elaborados planos de informação que localizaram as serrarias existentes, a infra-estrutura disponível para o deslocamento de pessoal e transporte da produção, como estradas, ferrovias e rios navegáveis e os recursos madeireiros disponíveis. Estes três planos forneceram informações sobre as áreas onde a atividade madeireira já atuava, servindo assim como indicativo da viabilidade econômica daquela área (trabalho em elaboração).
} 


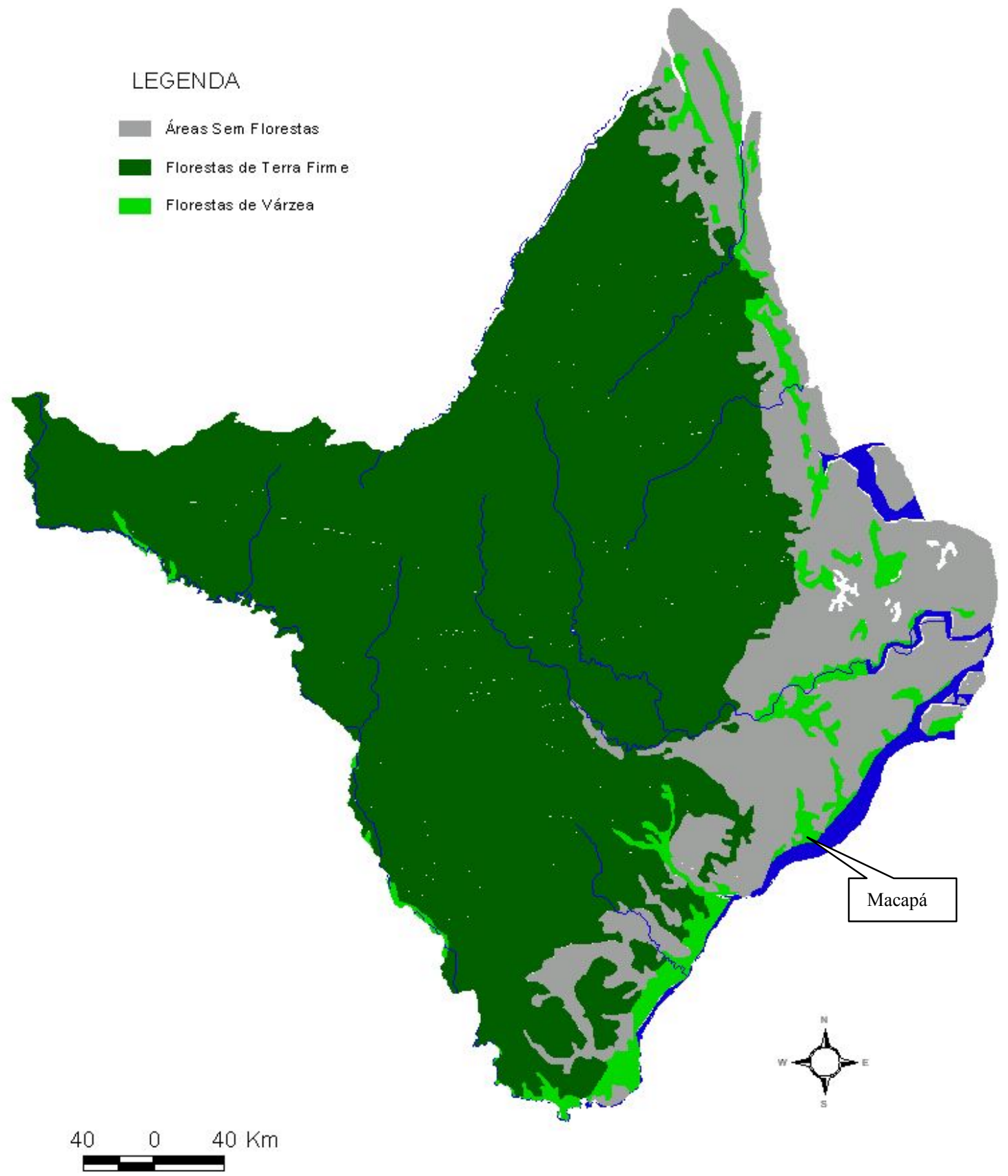

Figura 3 - Localização das áreas com florestas do Estado do Amapá (IBGE, 1997). 


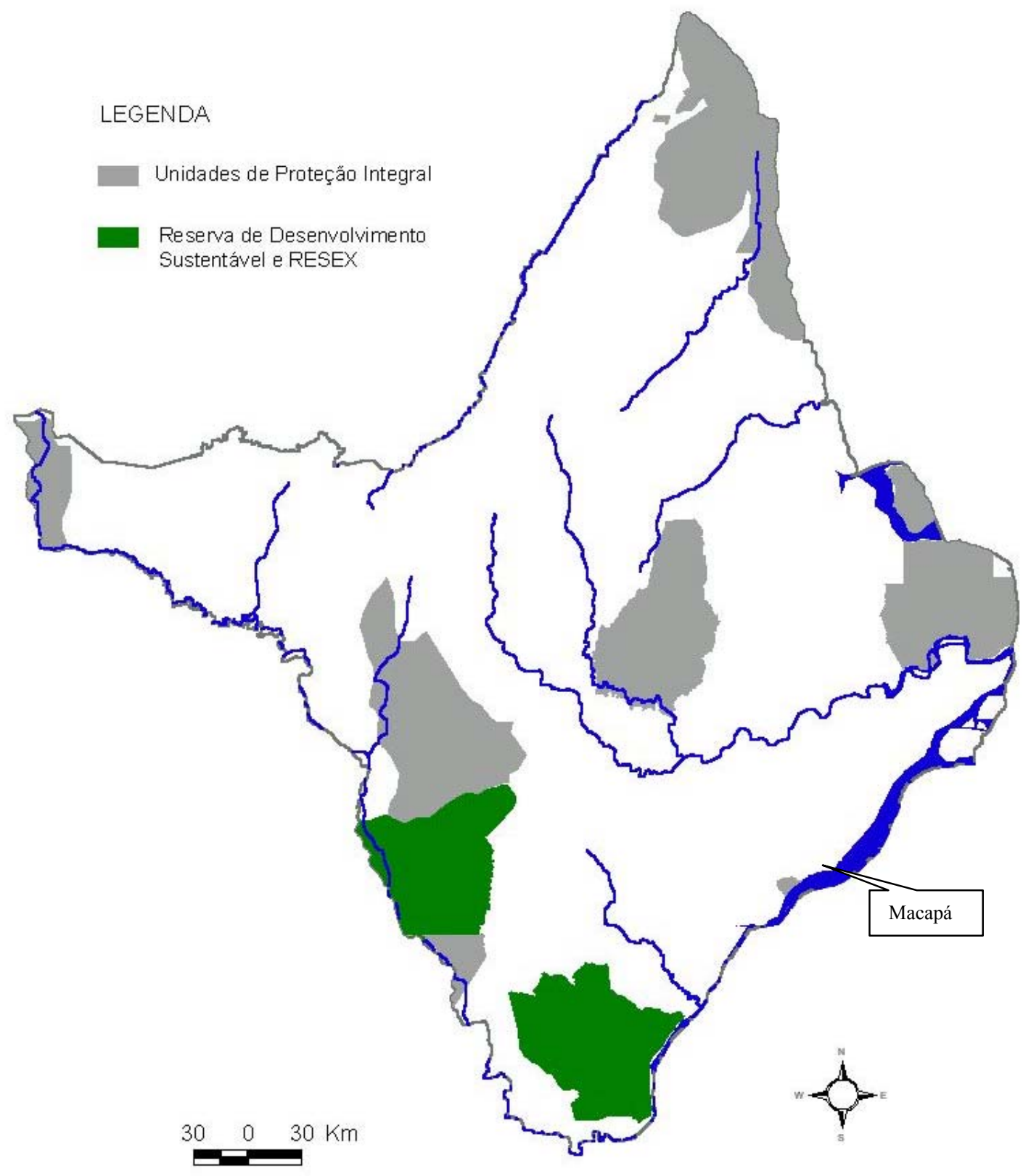

Figura 4 - Localização das unidades de conservação do Estado do Amapá (Veríssimo et al.. Trabalho em preparação) 


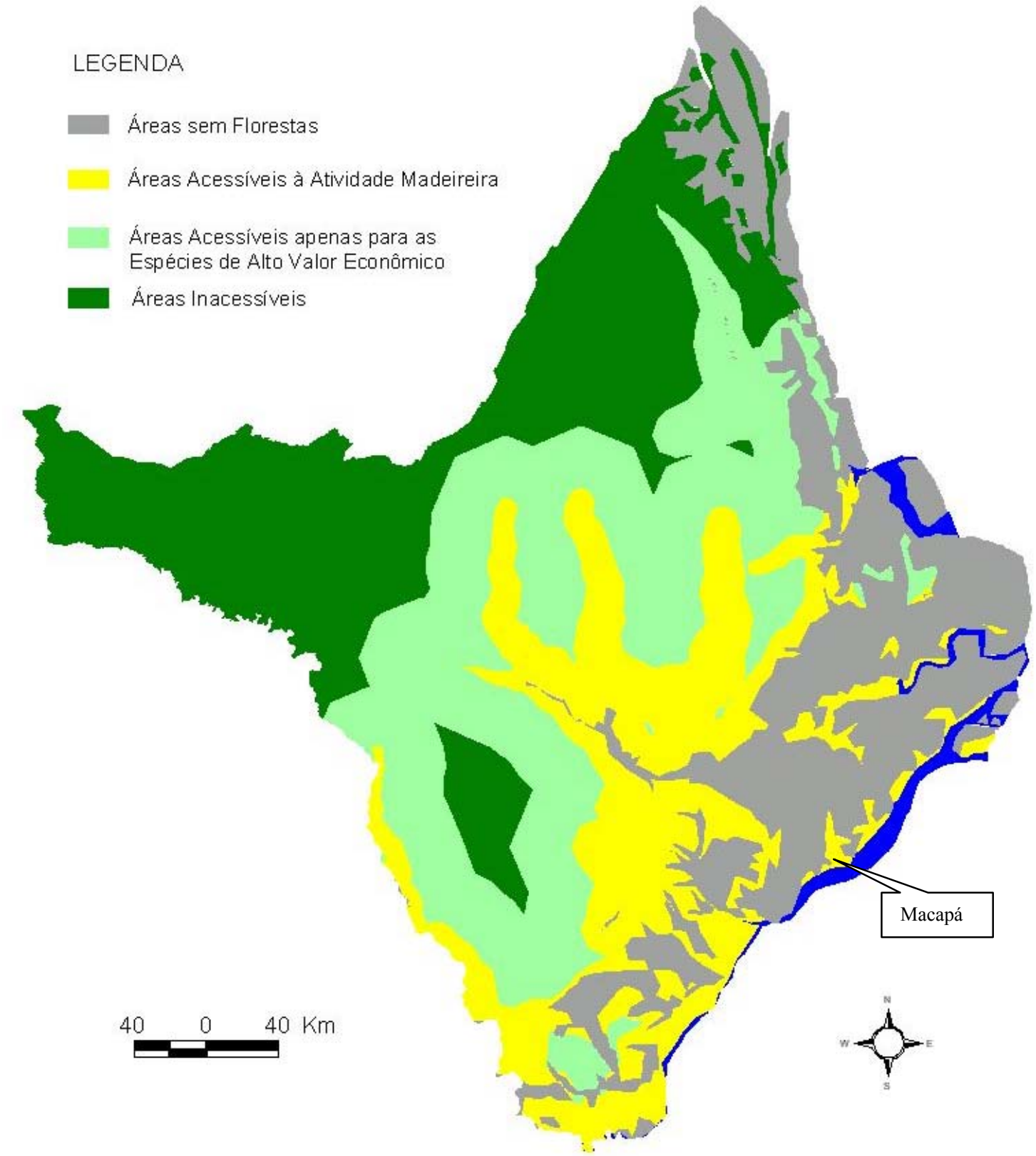

Figura 5 - Alcance econômico da atividade madeireira no Estado do Amapá (Veríssimo et al.. Trabalho em preparação). 


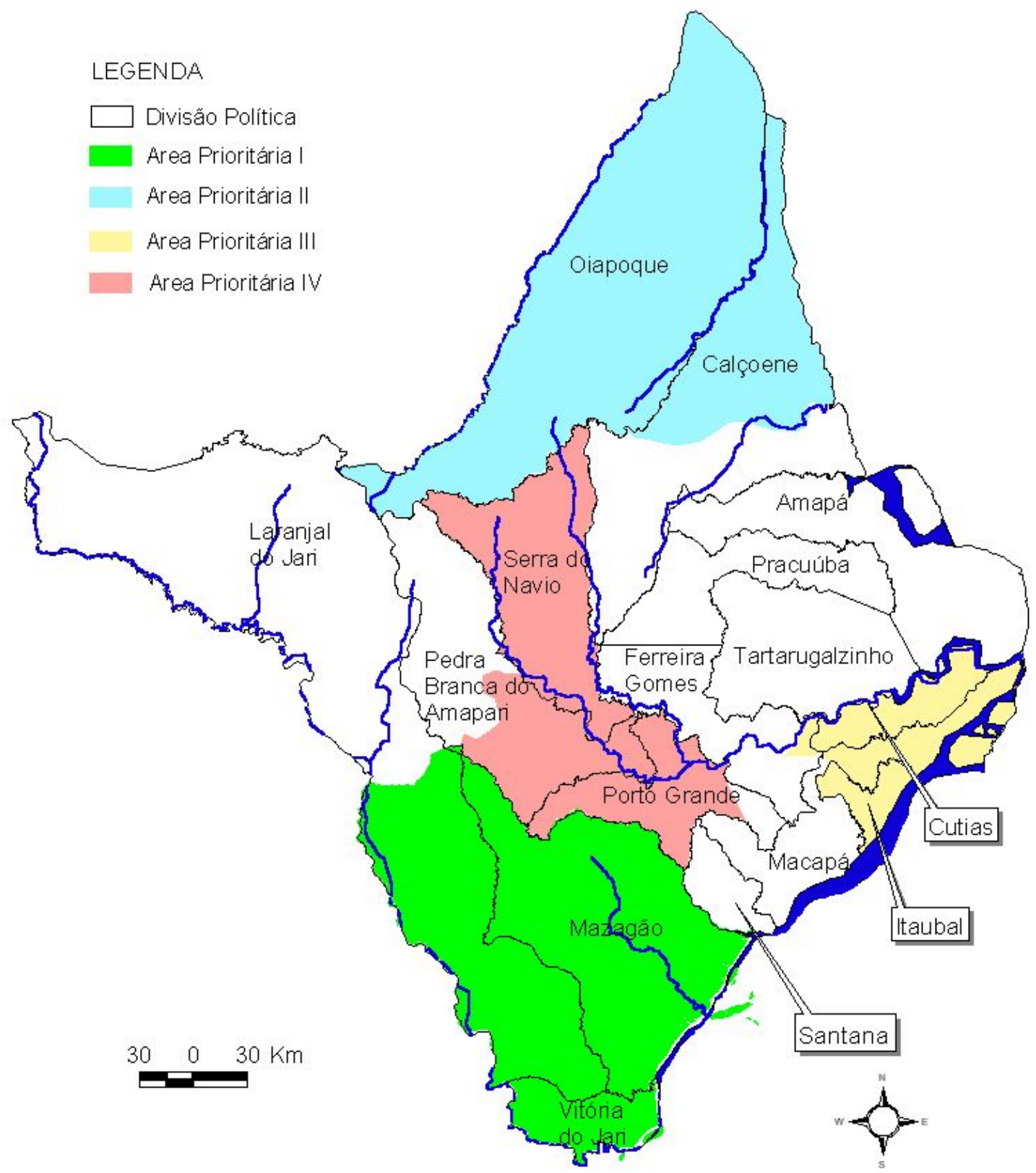

Figura 6 - Divisão política e áreas prioritárias do Estado do Amapá. 


\subsubsection{Escala Municipal}

Os municípios devem atender a três pré-requisitos para serem considerados potenciais para o desenvolvimento do manejo florestal. Os pré-requisitos são:

i. estar dentro da área com floresta, de terra firme ou várzea (Figura 3);

ii. estar incluído na área de alcance econômico a atividade madeireira (Figura 5);

iii. estar incluído nas áreas prioritárias 1,3 ou 4 (Figura 6).

Oito municípios atendem aos pré-requisitos e foram selecionados como potenciais para o desenvolvimento do manejo florestal. $O$ arquipélago de Bailique, pertencente ao município de Macapá, não atendeu aos critérios estabelecidos, mas algumas de suas comunidades foram amostradas a pedido da Secretaria Estadual de Agricultura e Florestas -SEAF.

Os municípios selecionados foram:
a. Ferreira Gomes;
b. Laranjal do Jarí;
c. Mazagão;
d. Pedra Branca do Amapari;
e. Porto Grande;
f. Vitória do Jarí;
g. Serra do Navio;
h. Macapá/Bailique.

Para o levantamento de campo foram identificados, através de informações da SEAF, como potenciais detentores de informações sobre os municípios abrangidos pelas áreas consideradas estratégicas para o desenvolvimento da atividade florestal os técnicos do órgão de extensão rural do Estado, Instituto de desenvolvimento rural do Estado do Amapá -RURAP- e os técnicos da Fundação Nacional de Saúde -FNS.

O primeiro passo ao se chegar a um município foi o contato e posterior entrevista com os técnicos da FNS responsáveis pelo município. Através destas 
entrevistas as comunidades eram localizadas espacialmente nos mapas, elaborados pelos técnicos, e seus líderes, já identificados. Os técnicos da FNS também forneceram informações relacionadas ao acesso e tempo de viagem necessários para se chegar às comunidades.

A menor unidade dos mapas da FNS eram as "localidades", nome pelo qual eram identificados os locais de ocupação humana, que poderiam ser compostos somente por uma única casa ou várias delas, agrupadas em uma comunidade. As "localidades" muitas vezes estavam distantes uma das outras, porém seus moradores se identificavam como pertencentes a uma dada comunidade, formada por várias outras "localidades".

Sendo que uma comunidade pode possuir mais do que uma "localidade" foi aplicado o critério de que se as famílias de uma dada "localidade" se reúnem e possuem suas atividades sociais e também escolares em uma outra "localidade" essas "localidades" constituem uma comunidade.

Com as comunidades do município já identificadas e plotadas no mapa (Figuras 7, 8, 9 e10), o passo seguinte foram as entrevistas com os técnicos do RURAP. Com eles foram preenchidas uma matriz lógica para cada comunidade do município. Nesta matriz, os técnicos atribuíam notas, de 1 a 3 , para cada parâmetro considerado importante para o desenvolvimento do manejo florestal. Sendo (1) para características que a comunidade POSSUIA, (2) para as que estavam em PLANEJAMENTO e (3) para as que NÃO POSSUIAM. Com a análise da matriz, eram identificadas as comunidades com maior potencial para o desenvolvimento da atividade, as que possuíssem a menor nota.

As variáveis dessa matriz foram as seguintes:

a. cobertura vegetal: conserva a reserva legal, tipo de uso, potencial madeireiro;

b. situação fundiária: legalizada, em processo de legalização, planos futuros de legalização, pertence a algum tipo de unidade de conservação ou já existe plano para ser incorporada;

c. organização social: existência de algum tipo de organização social; 
d. acesso ao mercado: possui vias de acesso, experiência com comercialização;

e. exploração florestal: histórico de exploração florestal madeireira, já explorou, planeja explorar ou nunca realizou atividades de colheita madeireira;

f. distância da fronteira madeireira: ocorrência de extração madeireira aos arredores da comunidade pode indicar viabilidade econômica da área;

g. extensão florestal: ocorrência de treinamentos e participação de comunitários em treinamentos.

Os critérios, utilizados para a seleção das comunidades, considerados como essenciais ao desenvolvimento da atividade foram a existência de alguma forma de organização social, capacidade para gerenciar o empreendimento e existência de área florestada com espécies de valor econômico.

\subsection{Levantamento sócio-econômico}

Foram visitadas 56 comunidades, nas áreas consideradas potenciais para o desenvolvimento das atividades de manejo florestal.

Segundo a FNS existem 2.230 "localidades" no Estado do Amapá. Entenda-se como localidade sítios, vilas, povoamentos, acampamentos, aldeias e garimpos ativos, toda presença humana estabelecida em dada área, mesmo sendo somente uma família é considerada uma localidade, como explicado anteriormente no item 3.2.2 Escala Municipal.

Todas as comunidades visitadas eram formadas por várias "localidades", mas mesmo se considerarmos que cada comunidade era formada por apenas uma localidade, $o$ levantamento chegaria a amostrar 2,5\% das comunidades do Estado. No caso dos municípios considerados potenciais para o desenvolvimento do manejo florestal a porcentagem de comunidades amostradas chega a 4,3\% (Tabela 2 ). 
Tabela 2. Número de localidades existentes nos municípios do Estado do Amapá (Fonte: FNS, 1999), número de comunidades amostradas e intensidade amostral.

\begin{tabular}{cccc}
\hline Município & Localidades & Comunidades Amostradas & Intensidade Amostral \\
\hline Ferreira Gomes & 129 & 3 & $2,3 \%$ \\
Laranjal do Jarí & 85 & 5 & $5,9 \%$ \\
Macapá/Bailique & 451 & 7 & $1,6 \%$ \\
Mazagão & 323 & 23 & $7,1 \%$ \\
Pedra Branca & 84 & 4 & $4,8 \%$ \\
Porto Grande & 119 & 6 & $5,0 \%$ \\
Serra do Navio & 33 & 5 & $15,2 \%$ \\
Vitória do Jarí & 65 & 3 & $4,6 \%$ \\
SUBTOTAL & $\mathbf{1 . 2 8 9}$ & $\mathbf{5 6}$ & $\mathbf{4 , 3 \%}$ \\
Santana & 153 & - & - \\
Tartarugalzinho & 232 & - & - \\
Oiapoque & 106 & - & - \\
Amapá & 101 & - & - \\
Pracuúba & 47 & - & - \\
Itaubal & 65 & - & - \\
Cutias & 74 & - & $\mathbf{2 , 5 \%}$ \\
Calçoene & 163 & - & \\
TOTAL & $\mathbf{2 . 2 3 0}$ & $\mathbf{5 6}$ &
\end{tabular}

O levantamento sócio-economico forneceu informações para que, dentre os municípios selecionados, fosse possível a identificação das comunidades que possuem maior potencial para o desenvolvimento do manejo florestal.

Identificadas as comunidades potenciais, estas receberam as visitas dos técnicos para o levantamento de informações sócio-econômicas, através de entrevistas, conduzidas por questionário, composto por questões relevantes para o desenvolvimento da atividade florestal, com as lideranças comunitárias previamente identificadas.

O questionário foi composto por questões comuns a todos os comunitários e algumas de ordem familiar. As variáveis pesquisadas foram as seguintes:

a. dados pessoais do entrevistado e sua família, como idade, ano de chegada a comunidade, local de origem e atividade anterior;

b. nome da comunidade, número de famílias, tempo de existência, e forma de acesso/ocupação; 
c. evolução do uso da terra, quando começaram a plantar, quanto essa atividade cresceu e quando começou a exploração florestal;

d. situação legal da terra;

e. informações sobre meios de transporte e acesso a comunidade;

f. informações sobre a infra-estrutura local como escolas, sedes sociais, igrejas, energia elétrica, posto médico, existência de estabelecimentos comercias, agências do governo;

g. sobre a organização social: grau de parentesco entre as famílias, existência de cooperativas, associações, cantina, clube de mães, se exercia algum cargo em alguma dessas organizações, existência de atividades coletivas como mutirões, celebrações religiosas, festas, como são resolvidos os conflitos;

h. sobre a liderança: como exerce essa liderança, como foi considerado liderança, reconhecimento de outras lideranças na comunidade;

i. disponibilidade de mão de obra, idade, escolaridade, treinamentos já executados na comunidade;

j. fontes de renda, acesso a crédito, produção agrícola familiar e comunitária;

k. produção florestal: madeira e não madeireiros, tipo de exploração utilizada.

Os questionário aplicados estão em anexo 6.4 e 6.5 .

Nas comunidades foram entrevistados as lideranças comunitárias, no mínimo uma por comunidade. Estes líderes também foram identificados na fase de pré-seleção das comunidades com os técnicos do RURAP e FNS, ou mesmo através de conversas informais com moradores da comunidade eleita.

Antes da entrevista o comunitário recebeu explicação sobre a pesquisa, seus objetivos, quem estava interessado nestes dados e quais as possibilidades do trabalho gerar resultados concretos para a comunidade. 


\section{RESULTADOS E DISCUSSÃO}

\subsection{Macro-zoneamento através da geo-exclusão}

Uma área de aproximadamente $29.838 \mathrm{Km}^{2}, 20,8 \%$ do território estadual, foi considerada economicamente viável para o desenvolvimento do manejo florestal, com aproveitamento de todas as espécies comerciais (Figura 11), como angelim vermelho (Dinizia excelsa) e rajado (Pithecelobium racemosum), maçaranduba (Manikara sp.), louro (Ocotea sp.), ipê (Tabebuia sp.), sucupira (Bowdichia sp.), freijó (Cordia sp.), jatobá (Hymenaea courbaril), piquiá (Caryocar villosum), jarana (Lecythis sp.), acapu (Vouacapoua americana), andiroba (Carapa guianensis), quaruba (Vochysia maxima) e paricá (Schizolobium sp.). Na várzea, pau-mulato (Calycophylum spruceanum), maçaranduba (Manilkara sp.), acapu (V. americana), macacaúba (Platymiscium sp.), andiroba (C.guianensis), jutaí (Hymenaeae sp.), pracuúba (Trichilia sp.), sapucaia (Lecythis sp.), virola (Virola surinamensis) e cedro (Cedrela sp.)

O macrozoneamento gerou, além do mapa de áreas potenciais para o manejo florestal, algumas informações secundárias importantes para o planejamento estadual como:

a. Aproximadamente $25 \%$ das áreas do Estado não são indicadas para o manejo florestal, são áreas de vegetação não florestal ou áreas já desmatadas, sendo assim excluídas para os fins deste estudo (Figura 3);

b. $17 \%$ do território estadual está legalmente protegido através das unidades de conservação ou reservas indígenas, áreas também excluídas para este estudo (Figura 4). 


\subsection{Os municípios potenciais}

Os municípios potenciais para o desenvolvimento das atividades de manejo florestal, de acordo com os critérios explicados na Metodologia (item 4.2.2) são Macapá, Mazagão, Laranjal do Jarí, Vitória do Jarí, Porto Grande, Ferreira Gomes, Serra do Navio e Pedra Branca do Amaparí (Figura 7).

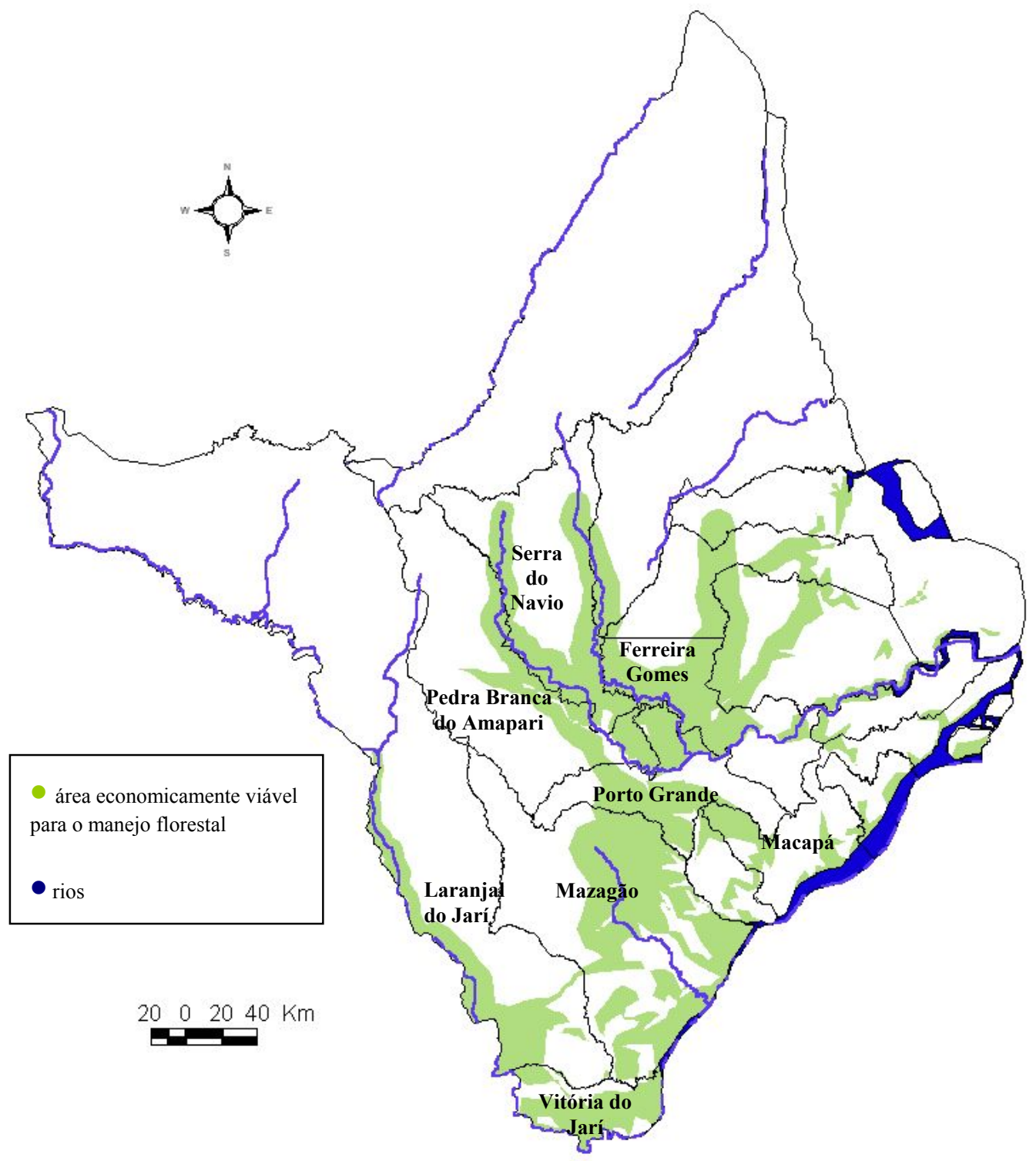

Figura 7 - Área de extração economicamente viável para todas as espécies comercias. 


\subsection{As comunidades}

Os critérios de avaliação das comunidades, através de entrevistas com os técnicos do RURAP e FNS, sobre aspectos da organização social e experiências comerciais não puderam ser obtidos, e posteriormente utilizados, através desta seleção prévia dos municípios. Normalmente os técnicos do RURAP e FNS sabiam dizer que existia alguma forma de organização social mas não exatamente se era uma comissão de pais para administrar a escola ou algo mais abrangente que poderia administrar todas as outras atividades realizadas em comum.

As questões comerciais também obtinham respostas muito generalizadas, como no caso das questões a respeito da comercialização de madeira todos respondiam que dado município possuía atividade madeireira, mas não conseguiam identificar quais as comunidades que estavam fazendo a extração.

As comunidades identificadas como potenciais para o desenvolvimento do Manejo Florestal Comunitário, segundo os critérios explicados em Material e Métodos (item 3.2.2), são as enumeradas na tabela 3, abaixo.

Tabela 3. Comunidades amostradas, número de famílias e de entrevistados.

\begin{tabular}{|c|c|c|c|c|c|c|}
\hline \multirow{2}{*}{ Número } & \multirow[t]{2}{*}{ Comunidade } & \multirow[t]{2}{*}{ Município } & \multirow{2}{*}{$\begin{array}{c}\text { Nº de } \\
\text { Famílias }\end{array}$} & \multirow{2}{*}{$\begin{array}{c}\mathrm{N}^{\circ} \text { de } \\
\text { Entrevistados }\end{array}$} & \multicolumn{2}{|c|}{ Ano da Entrevista } \\
\hline & & & & & 1999 & 2000 \\
\hline 1 & Assent. Vila do Maracá & Mazagão & 724 & 3 & $x$ & $x$ \\
\hline 2 & Santa Clara & Mazagão & 19 & 1 & $x$ & \\
\hline 3 & Santo Antonio do Camaipi & Mazagão & 7 & 1 & $x$ & \\
\hline 4 & Vila Betel & Mazagão & 28 & 3 & $x$ & $x$ \\
\hline 5 & Santa Maria do Curuça & Mazagão & 19 & 2 & $x$ & $x$ \\
\hline 6 & Santa Ana & Mazagão & 8 & 4 & $x$ & $x$ \\
\hline 7 & Santo Antonio do Mutuacá & Mazagão & 20 & 1 & $x$ & \\
\hline 8 & Sororoca & Mazagão & 17 & 1 & $x$ & \\
\hline 9 & São José do Maracá & Mazagão & 11 & 1 & $x$ & \\
\hline 10 & Ramal do Pioneiro & Mazagão & 20 & 3 & $x$ & $x$ \\
\hline 11 & São Benedito do Rio Urubueno & Mazagão & 7 & 1 & $x$ & \\
\hline 12 & Salvador Deus Proverá & Mazagão & 4 & 1 & $x$ & \\
\hline 13 & Maranata & Mazagão & 20 & 3 & $x$ & $x$ \\
\hline 14 & Tambaqui & Mazagão & 8 & 2 & $x$ & $x$ \\
\hline 15 & Bispo & Mazagão & 4 & 2 & $x$ & $x$ \\
\hline
\end{tabular}


Tabela 3. Comunidades amostradas, número de famílias e de entrevistados.

\begin{tabular}{|c|c|c|c|c|c|c|}
\hline \multirow{2}{*}{ Número } & \multirow[t]{2}{*}{ Comunidade } & \multirow[t]{2}{*}{ Município } & \multirow{2}{*}{$\begin{array}{c}\mathrm{N}^{\circ} \text { de } \\
\text { Famílias }\end{array}$} & \multirow{2}{*}{$\begin{array}{c}\mathrm{N}^{\circ} \text { de } \\
\text { Entrevistados }\end{array}$} & \multicolumn{2}{|c|}{ Ano da Entrevista } \\
\hline & & & & & 1999 & 2000 \\
\hline 16 & Espinhel & Mazagão & 60 & 1 & $x$ & \\
\hline 17 & Assent. do Silvestre & Serra do Navio & 45 & 5 & $x$ & $\mathrm{X}$ \\
\hline 18 & Água Branca & Serra do Navio & 600 & 1 & $x$ & \\
\hline 19 & Capivara & Serra do Navio & 17 & 1 & $x$ & \\
\hline 20 & Jararaca & Serra do Navio & 10 & 1 & $x$ & \\
\hline 21 & Perpetuo Socorro & Serra do Navio & 80 & 1 & $x$ & \\
\hline 22 & Sete Ilhas & Pedra Branca & 42 & 1 & $x$ & \\
\hline 23 & Tucano I & Pedra Branca & 30 & 4 & $x$ & $X$ \\
\hline 24 & Água Fria & Pedra Branca & 62 & 4 & $x$ & $X$ \\
\hline 25 & Tucano II & Pedra Branca & 50 & 1 & $x$ & \\
\hline 26 & Triunfo & Ferreira Gomes & 39 & 1 & $x$ & \\
\hline 27 & São Raimundo & Ferreira Gomes & 46 & 1 & $x$ & \\
\hline 28 & Assent. Nova Vida & Ferreira Gomes & 50 & 1 & $x$ & \\
\hline 29 & Assent. Nova Canãa & Porto Grande & 240 & 1 & $x$ & \\
\hline 30 & Ramal do Cachaço & Serra do Navio & 30 & 4 & $x$ & $X$ \\
\hline 31 & São Sebastião do Cachaco & Porto Grande & 55 & 1 & $x$ & \\
\hline 32 & Assent. do Munguba & Porto Grande & 301 & 3 & $x$ & $X$ \\
\hline 33 & Santa Maria do Vila Nova & Porto Grande & 129 & 1 & $x$ & \\
\hline 34 & São Francisco do Iratapuru & Laranjal do Jari & 37 & 1 & $x$ & \\
\hline 35 & Cachoeira de S.Antonio do Jari & Laranjal do Jari & 23 & 1 & $x$ & \\
\hline 36 & Padaria & Laranjal do Jari & 95 & 1 & $x$ & \\
\hline 37 & Água Branca & Laranjal do Jari & 66 & 1 & $x$ & \\
\hline 38 & Tira couro & Laranjal do Jari & 15 & 1 & $x$ & \\
\hline 39 & Aterro do Muriacá & Vitória do Jari & 17 & 1 & $x$ & \\
\hline 40 & Matauaú & Vitória do Jari & 10 & 1 & $x$ & \\
\hline 41 & Jarilândia & Vitória do Jari & 71 & 1 & $x$ & \\
\hline 42 & Marinheiro de Fora & Macapá & 36 & 3 & $x$ & $X$ \\
\hline 43 & Igaçaba & Macapá & 22 & 4 & $x$ & $X$ \\
\hline 44 & Jaburuzinho & Macapá & 35 & 1 & $x$ & \\
\hline 45 & Buritizal & Macapá & 38 & 3 & $x$ & $X$ \\
\hline 46 & Livramento do Bailique & Macapá & 17 & 3 & $x$ & $X$ \\
\hline 47 & Menino Deus & Mazagão & 20 & 1 & & $\mathrm{X}$ \\
\hline 48 & Assentamento Nova Colina & Porto Grande & 8 & 1 & & $X$ \\
\hline 49 & Açaituba & Mazagão & 5 & 2 & & $X$ \\
\hline 50 & Irapi & Mazagão & 7 & 1 & & $X$ \\
\hline 51 & Filadélfia & Mazagão & 6 & 1 & & $x$ \\
\hline 52 & Retiro do Ariramba & Mazagão & 6 & 1 & & $X$ \\
\hline 53 & Santo Antonio & Mazagão & 6 & 1 & & $X$ \\
\hline 54 & S.Antonio/Braço do Ajuruxi & Mazagão & 12 & 2 & & $X$ \\
\hline 55 & Limão do Curuá & Macapá & 40 & 4 & & $X$ \\
\hline 56 & Franquinho & Macapá & 16 & 2 & & $X$ \\
\hline & & Total & 3410 & 100 & & \\
\hline
\end{tabular}




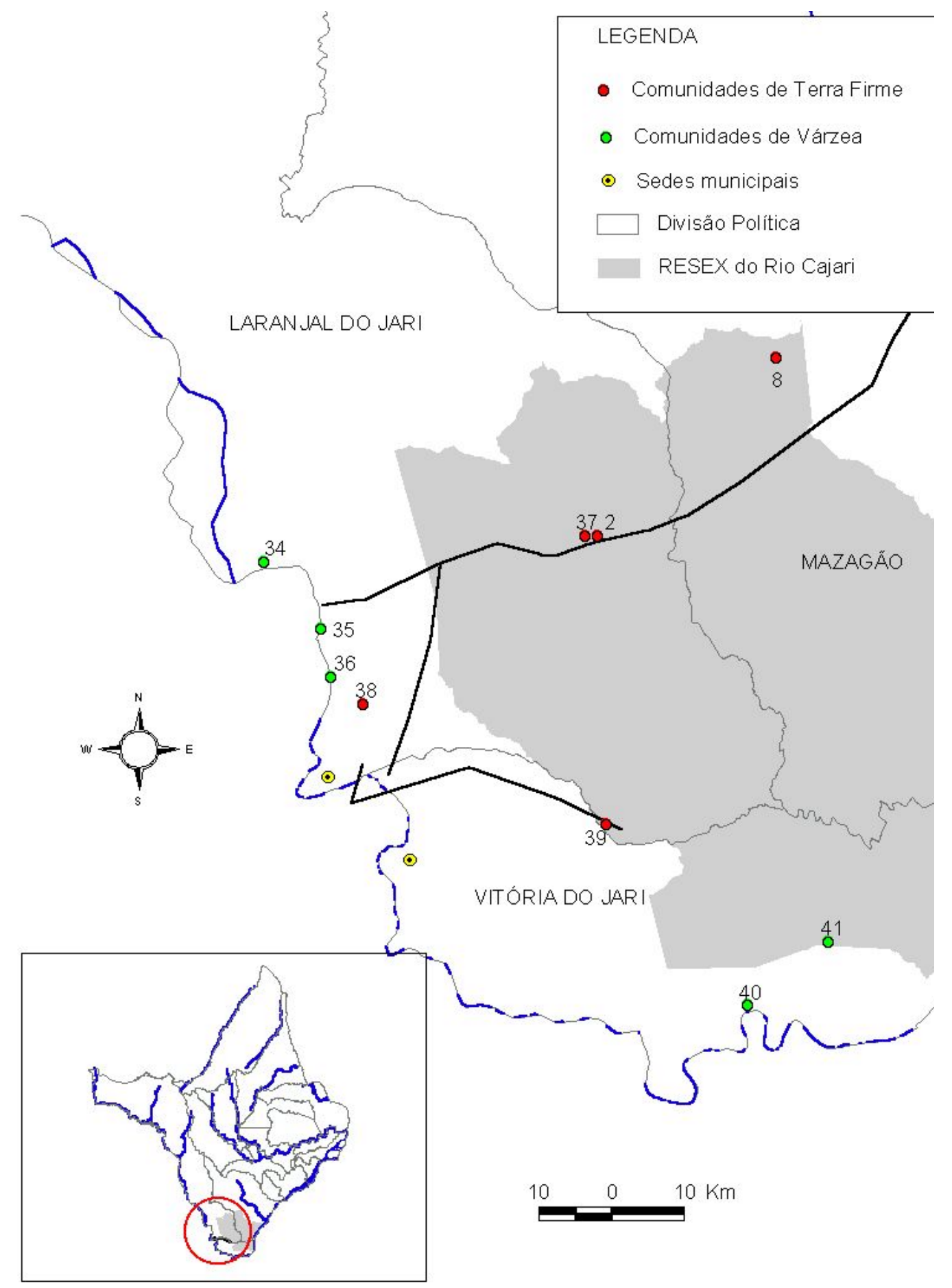

Figura 8 - Comunidades visitadas na região dos municípios Laranjal do Jarí, Vitória do Jarí e região ocidental de Mazagão. 


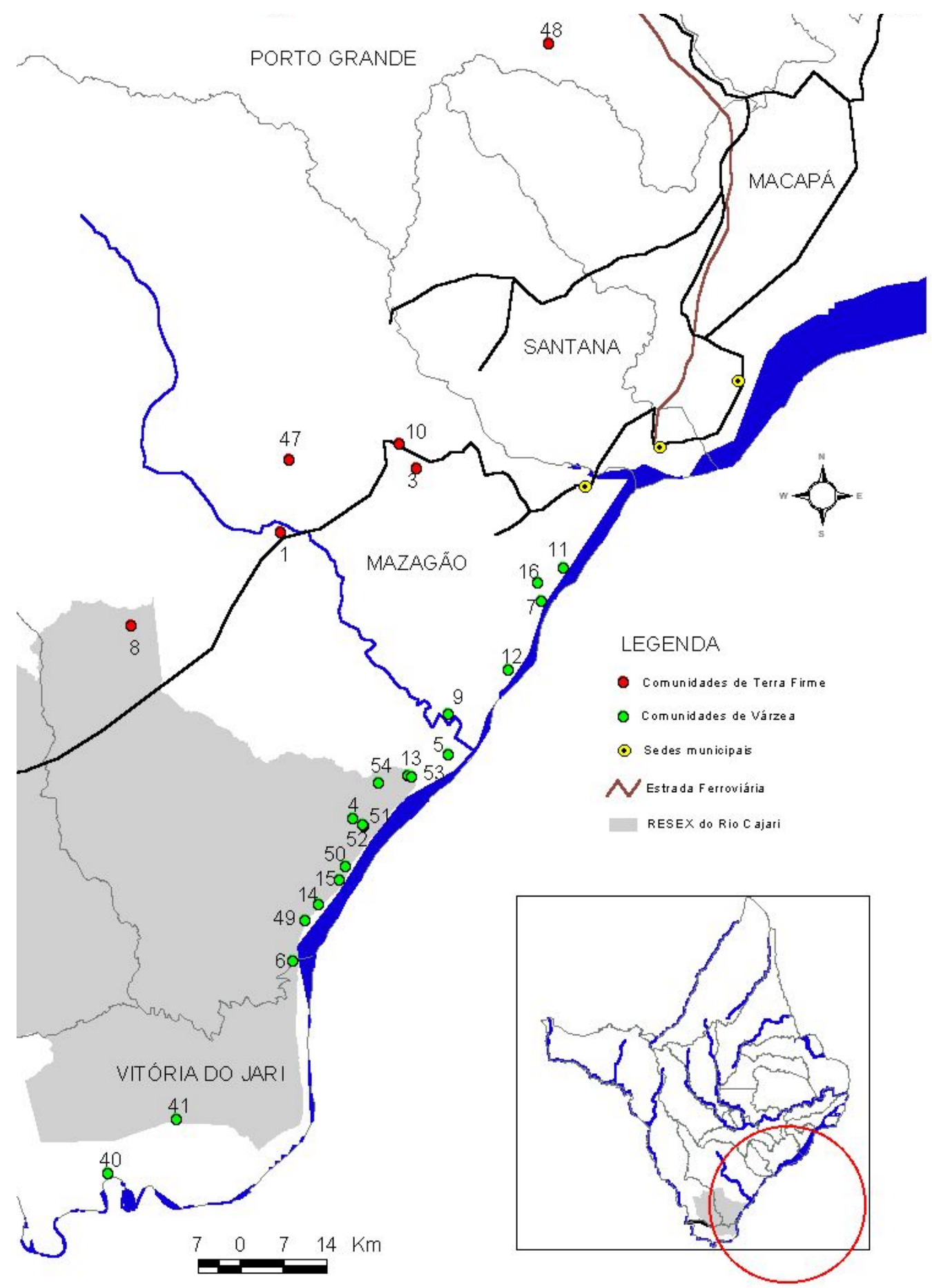

Figura 9 - Comunidades visitadas no município de Mazagão e na face oriental do Vitória do Jarí. 


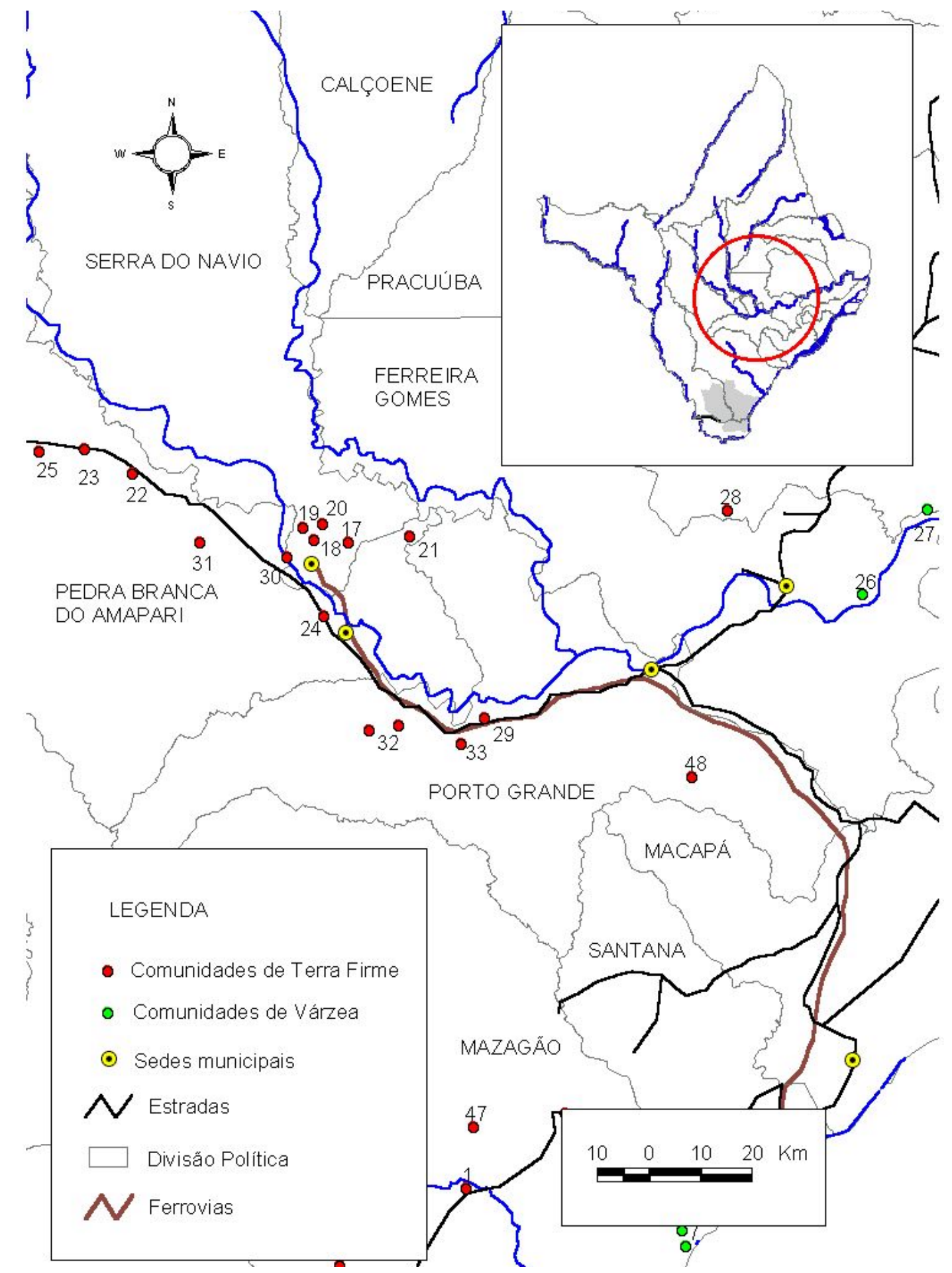

Figura 10 - Comunidades visitadas na região central do Amapá. 


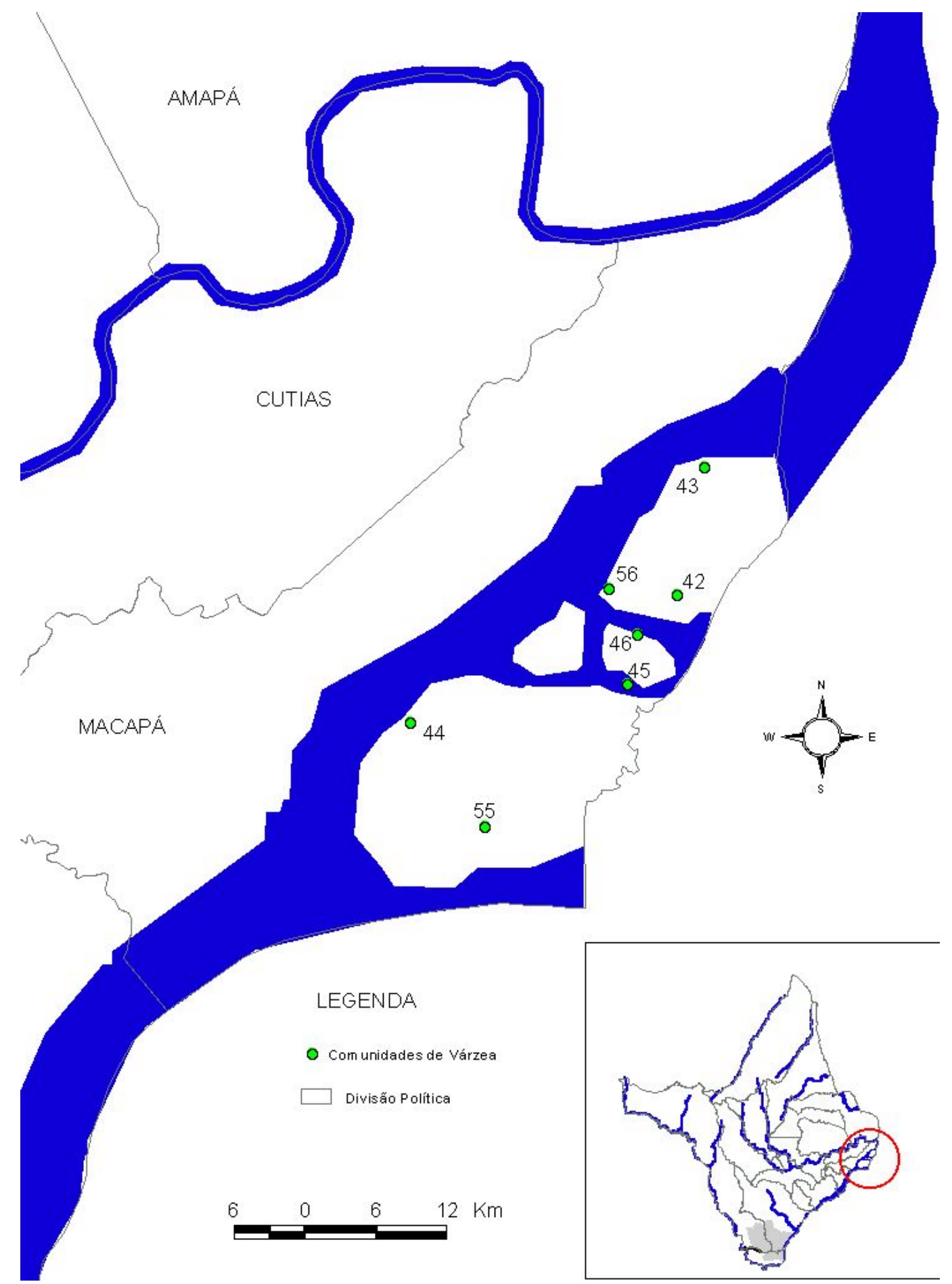

Figura 11 - Comunidades visitadas na região do arquipélago do Bailique. 
As comunidades foram classificadas quanto a região de localização, "terra firme", "várzea" e "bailique", que são algumas ilhas do rio Amazonas (Figura 12).

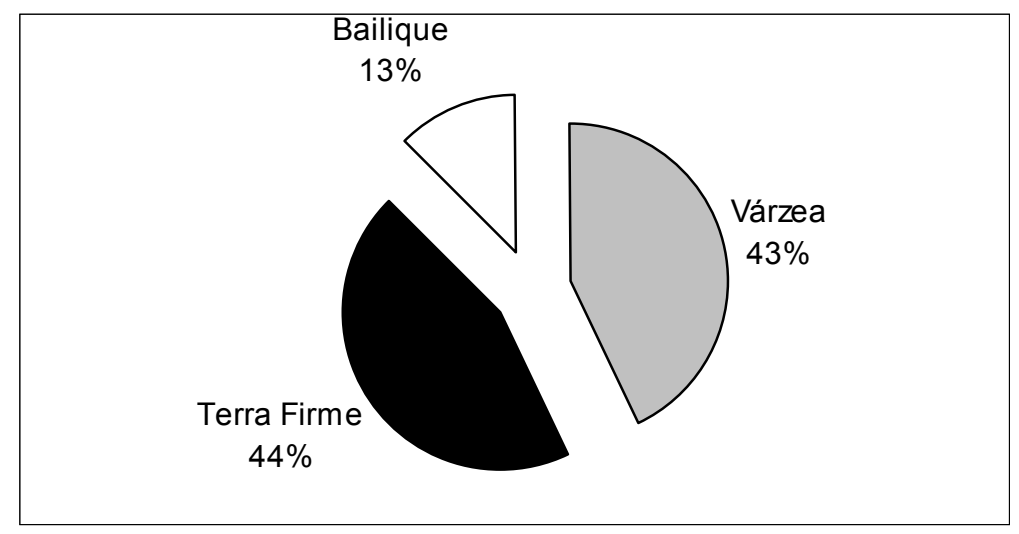

Figura 12 - Distribuição das comunidades amostradas por região.

As comunidades apresentam um número médio de 62 famílias, porem somente 11 das 56 comunidades caracterizadas, possuem mais de 61 famílias. A maioria das comunidades possuem entre 4 e 50 famílias, esta classe representa $78,6 \%$ das comunidades amostradas (Figura 13).

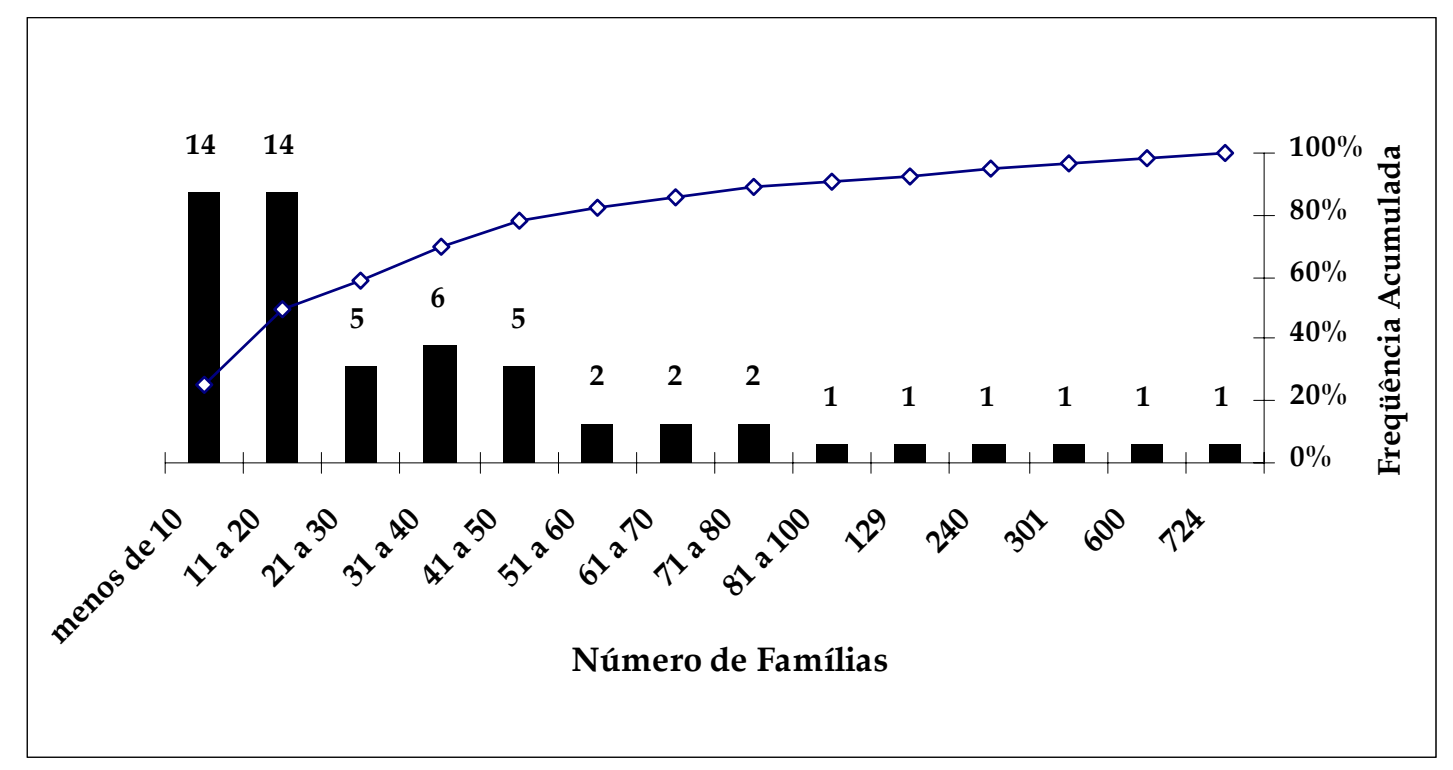

Figura 13 - Número de comunidades por classe de famílias e \% acumulada de famílias. 
Apesar das comunidades amostradas estarem bem divididas entre as regiões, o número de famílias é muito distinto entre uma região e outra, estando a grande maioria das famílias em terra firme (78\%), devido a reforma agrária que promoveu vários assentamentos em áreas anteriormente ocupadas pela Floresta Amazônica (Figura 14).

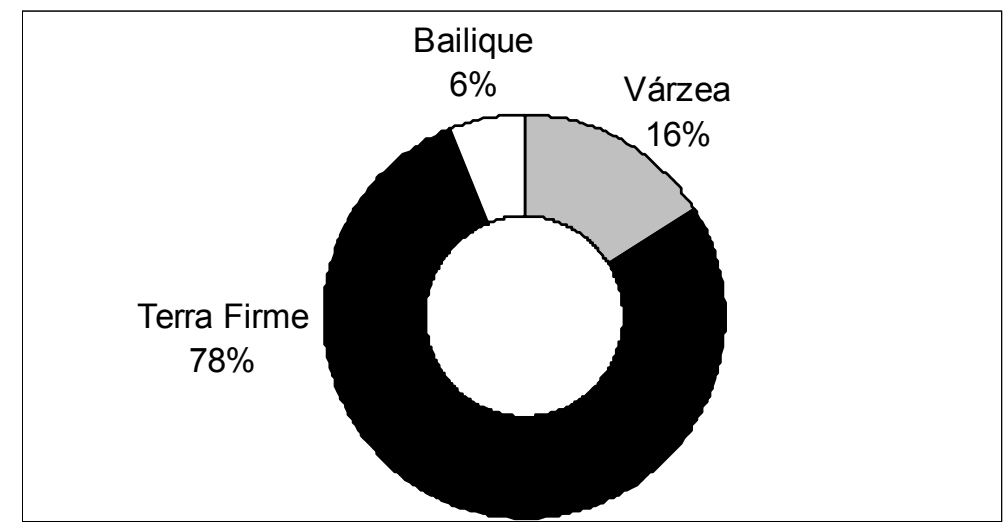

Figura 14 - Localização das famílias das comunidades visitadas.

A maioria das famílias são do Estado do Amapá (62\%), e o Estado do Pará colabora com $23 \%$ das famílias entrevistadas. Também possuem representantes entre as famílias das comunidades do Amapá os Estados do Maranhão, Piauí, Mato Grosso, Rio Grande do Norte, Bahia e Minas Gerais. (Figura 15.)

Com a fronteira agrícola se deslocando para a região amazônica e sendo o Estado do Amapá considerado um grande espaço vazio para as autoridades responsáveis pela reforma agrária, existe uma tendência para o aumento das "comunidades" formadas por assentamentos.

A questão preocupante é que nos assentamentos que visitamos a maioria das famílias não tinham tradição agrícola e muito menos intimidade com a floresta e os produtos que ela poderia oferecer, então a alternativa econômica que encontraram para a floresta que estava em seus lotes, foi o carvão, já que a maioria dos assentamentos do Amapá está fora da área economicamente viável para a exploração da madeira. 


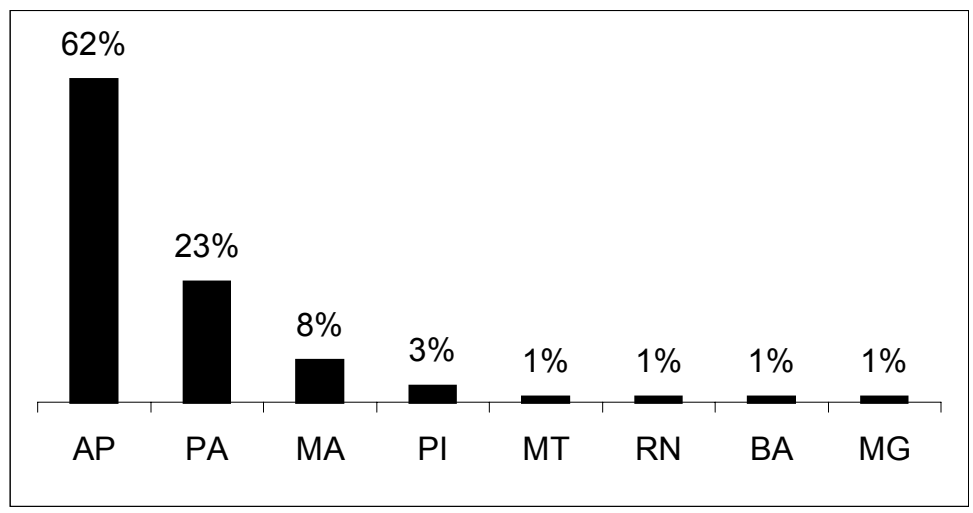

Figura 15 - Origem das famílias componentes das comunidades.

As famílias apresentam um número médio de componentes variado, como podemos observar na tabela 4 , sendo que as famílias da várzea possuem o maior número médio de componentes. As famílias que ocupam a várzea amapaense podem ser consideradas as mais antigas do Estado. Porém o fato de já estarem na mesma área a algumas décadas, não explica o que propicia a segurança para a formação de famílias com um maior número de componentes.

Tabela 4. Número médio de componentes das famílias separadas pela região de ocupação.

\begin{tabular}{cccc}
\hline & Várzea & Bailique & Terra Firme \\
\hline $\mathrm{n}^{\mathrm{o}}$ médio de componentes & 8,8 & 6,6 & 6,5 \\
desvio padrão & 3,9 & 5,0 & 3,6 \\
\hline
\end{tabular}

Cerca de $50 \%$ das pessoas residentes nas comunidades amostradas são crianças. A faixa de jovens e adolescentes (12 a 20 anos) corresponde a 25\%. Adultos de 20 a 60 anos formam $20 \%$ destas comunidades. A população de idosos é pequena, entre 3 a $4 \%$. Não foram encontradas grandes diferenças entre a distribuição por faixa etária na região da várzea (neste caso incluindo o arquipélago do Bailique) e terra firme (Figura 16).

Para as comunidades não seria um impedimento, se compatibilizada com a disponibilidade, a quantidade de mão de obra para desenvolverem as atividades relacionadas ao manejo florestal neste momento, porém a distribuição de pessoas nas diferentes faixas etária não se assemelha a uma distribuição normal, possuindo um 
grande número de indivíduos com menos de 12 anos de idade, sendo a somatória desses duas vezes maior que a somatória dos indivíduos adultos. Um grande grupo é formado quando somamos as crianças e jovens, agrupando quase $80 \%$ dos indivíduos nessas duas classes.

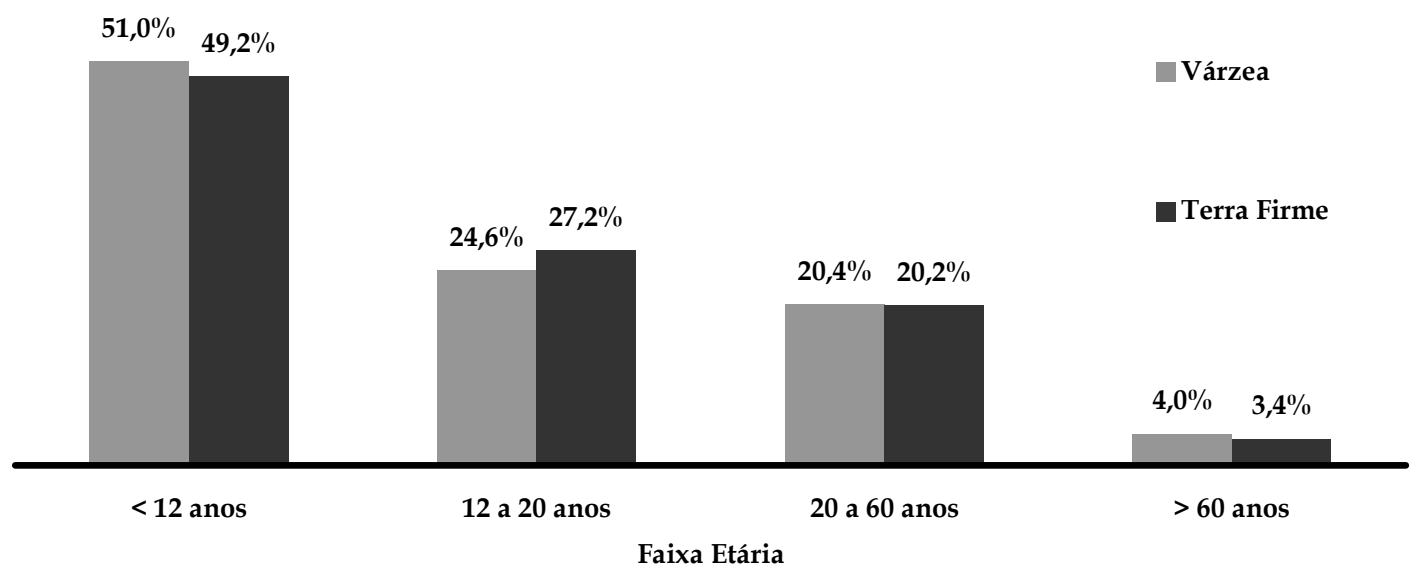

Figura 16 - Número de comunitários separados por classe de idade, crianças, jovens, adultos e velhos.

Esse comportamento da concentração dos indivíduos nas classes de idade infantil pode ser um sinal de que os indivíduos jovens estão migrando para outras regiões, normalmente em busca de emprego. Se esse comportamento persistir, a longo prazo as comunidades terão problemas de mão-de-obra para as futuras operações do manejo florestal, caso esse se tornar uma prioridade do Estado para o desenvolvimento regional.

Existe demanda para a madeira e outros produtos florestais, e essas comunidades estão localizadas nas áreas mais viáveis para a produção, possuindo estoque florestal e pessoal suficiente para o início das operações florestais. Entretanto, se a causa desse comportamento migratório for somente trabalho e renda, o manejo florestal poderia reverter esse quadro, oferecendo mais uma oportunidade de renda, para que o jovem possa continuar em sua comunidade e lá constituir família.

O investimento em capacitação profissional, para atender a possível demanda por profissionais especializados em práticas de manejo e processamento de madeira, 
pode ser o primeiro passo para o desenvolvimento de um programa de governo, de médio prazo, que pretenda investir no potencial florestal e madeireiro do Estado, criando assim um atrativo natural para que o jovem permaneça em sua comunidade.

\subsubsection{Formas de ocupação das áreas}

A grande maioria, $88 \%$, dos entrevistados acessaram as áreas, onde estão atualmente estabelecidos, pacificamente. Desse grupo, $12 \%$ das famílias entrevistadas já possuem contrato de concessão de uso emitido pelo INCRA e 15\% das famílias obtiveram o reconhecimento da posse depois de vários anos de ocupação. Apenas 9,5\% dos comunitários compraram a terra (Figura 17).

Dentre as famílias entrevistadas somente $1 \%$ delas teve acesso à terra de forma conflituosa. Esse pequeno valor pode ser devido a extremamente baixa densidade populacional do Estado, cerca de 434.781 habitantes em um território de $143.453 \mathrm{Km}^{2}$, resultando em 3,77 habitantes por $\mathrm{Km}^{2}$.

Este resultado foi obtido tendo como unidade amostral as famílias entrevistadas, e não a comunidade como um todo, devido aos diferentes modos de ocupação que são encontrados dentro de uma mesma comunidade, já que as famílias podem ter ocupado a terra de forma diferente e em momentos distintos. Nas comunidades onde isso foi observado, houve uma migração de grupos de famílias de uma comunidade para outra, sendo os motivadores os mais variados, como religioso, formas de acesso, legalização de novas áreas e disponibilidade de postos de trabalho. 


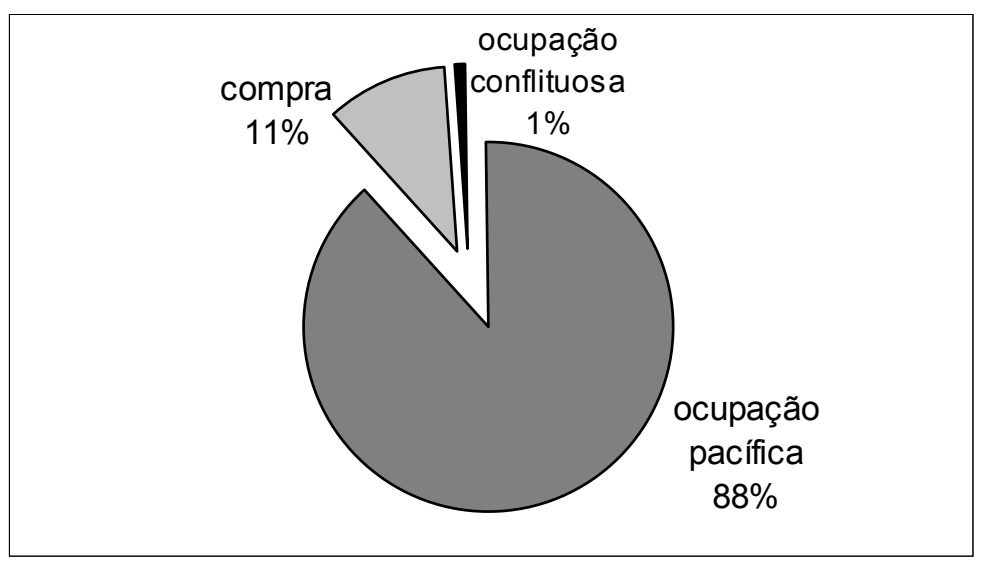

Figura 17 - Forma de ocupação a terra pelas famílias.

O histórico de ocupação pacífica ou já resolvida através da compra da terra, 99\% das famílias entrevistadas, representa um quadro favorável para o manejo florestal e também uma oportunidade para as famílias que ainda não possuem título legal de posse da terra. Para se aprovar um projeto de manejo é necessário a comprovação da posse legal da área a ser manejada, se o manejo for uma das prioridades do governo, a comunidade terá mais um motivador e um aliado para, aquelas famílias que ainda não possuem, a requisição e conquista legal da posse.

A sociedade como um todo ganha com essa regularização, pois não é interessante para o governo a manutenção das grandes porções de áreas consideradas terras devolutas, que futuramente podem ainda ser saqueadas ou serem objeto de litígio conflituoso pela determinação da posse e direito de uso.

Novas experiências de manejo florestal comunitário são importantes para o desenvolvimento deste modelo de uso dos recursos florestais neste momento em que novas alternativas são procuradas pelos órgãos de desenvolvimento agrário, como o Ministério de Desenvolvimento Agrário, responsável pela reforma agrária. Com esta situação propícia, que une vontade política e possibilidade material, já que mais de $80 \%$ do território do Estado do Amapá está sob administração do INCRA, o Amapá pode ter uma oportunidade única de desenvolvimento regional e regularização fundiária.

Para o MFC esta poderia ser a maior conquista, onde problemas e entraves seriam tratados, pelo governo e órgãos de licenciamento ambiental, como são em uma 
grande empresa, pois com a escala de produção potencialmente grande além dos benefícios diretos para a sociedade, como renda familiar, o governo poderia ser beneficiado através do impostos que recaem sobre a produção e comércio, e assim também indiretamente o MFC poderia melhorar a qualidade de vida da sociedade.

\subsubsection{Atividades econômicas}

Do total de entrevistados 57\% tem como sua principal atividade econômica a agricultura, $10 \%$ o extrativismo vegetal não madeireiro e $6 \%$ a pesca (Tabela 5 ).

Atualmente a atividade de extrativismo vegetal é baixa entre as famílias entrevistadas, e o manejo nem aparece como uma das fontes de renda, isso pode ser explicado pela ilegalidade que cerca essa atividade, com receio disso, acabam simplesmente omitindo, e até mesmo negando, que a atividade madeireira possui participação na formação de sua renda.

Para muitos, a floresta ainda é tida somente como uma proteção à terra, que futuramente será utilizada para a agricultura, já que as atividades de manejo florestal lhes parece legalmente impossível. Muito dessa postura se explica pela falta de tradição na exploração florestal madeireira, mas principalmente as dificuldades técnicas que esta atividade possui, já que a elaboração de um plano de manejo não é uma atividade simples para uma comunidade. A necessidade da assistência técnica para a realização do manejo florestal fica ainda mais patente nestes casos. 
Tabela 5. Principais atividades econômicas dos entrevistados.

\begin{tabular}{cc}
\hline Atividade & Freqüência \\
\hline Agricultura & $\mathbf{5 7 \%}$ \\
Extrativismo & $\mathbf{1 0 \%}$ \\
Pesca & $\mathbf{6 \%}$ \\
Educação & $\mathbf{4 \%}$ \\
Serraria & $\mathbf{3 \%}$ \\
Carpintaria & $\mathbf{3 \%}$ \\
Motorista & $\mathbf{2 \%}$ \\
Funcionalismo Público & $\mathbf{2 \%}$ \\
Comércio & $\mathbf{3 \%}$ \\
Estudante & $\mathbf{2 \%}$ \\
Garimpo & $\mathbf{2 \%}$ \\
Pecuária & $\mathbf{1 \%}$ \\
Polícia Ambiental & $\mathbf{1 \%}$ \\
Movelaria & $\mathbf{1 \%}$ \\
Religião & $\mathbf{1 \%}$ \\
Trabalho doméstico & $\mathbf{1 \%}$ \\
Construção Civil & $\mathbf{1 \%}$ \\
\hline
\end{tabular}

\subsubsection{Organização social}

Aproximadamente $16 \%$ das comunidades caracterizadas não possuem algum tipo de organização comunitária formal ou não participam de organizações comunitárias. Porém, $82 \%$ dos entrevistados participam de algum tipo de associação dentro da comunidade.

Vinte e cinco porcento das comunidades possuem cooperativas. Essas cooperativas estão localizadas em comunidades que possuem associação, sendo neste caso a única exceção a comunidade São Francisco do Iratapuru, em Laranjal do Jarí.

Outras organizações comunitárias citadas foram: caixa escolar, conselho comunitário e "Colônia de Pescadores" (5,4\% cada); grupo de jovens, sindicatos e núcleos de base - para organizar as atividades econômicas da comunidade (3,6\% cada); e grupos de terceira idade, com $1,8 \%$. 
Cerca de $46 \%$ das comunidades possui apenas uma organização (associação ou cooperativa). Cerca de $25 \%$ possuem duas organizações (na metade destes casos $-12,5 \%$ dos $25 \%$ - associação e cooperativa), $11 \%$ três organizações e apenas 1 comunidade $(1,8 \%)$ possui quatro organizações sociais (Tabela 6$)$.

As associações e cooperativas são as organizações comunitárias mais antigas, possuindo em média 5,4 anos de idade. Caixas escolares ${ }^{2}$ e sindicatos vem depois, com 3,5 e 3 anos, respectivamente. Os grupos de jovens encontrados tem cerca de 1 ano. Não foram citadas outras formas de organização (Tabela 6).

De uma forma geral, a organização social das comunidades no Estado do Amapá é bastante tímida. Porém, organizações que integram diversas comunidades (ASTEX-CA, AMAEX-CA, ATEXMAR, APRONORTE, COOPESSERRA, COOPENORTE, Conselho Comunitário do Arquipélago do Bailique, Colônia de Pescadores e outras), contam com um grande número de filiados, conseguem uma captação razoável de recursos e tem oportunidades de desenvolver importantes ações para o desenvolvimento do Estado.

Já organizações sociais internas das comunidades (associações de moradores e produtores locais) enfrentam problemas de organização relacionados ao gerenciamento das atividades e ao mandato das lideranças, participação dos associados e falta de recursos. Em grande parte dos casos, conseguem apenas desenvolver algumas obras de infraestrutura, limpeza de áreas, mutirões, manutenção dos grupos geradores para eletricidade, organização do transporte de excedentes agrícolas e extrativistas. Essas ações não são suficientes para afetar significativamente as atividades, expectativas ou qualidade de vida de seus associados.

\footnotetext{
2 A caixa escolar é um "mecanismo de descentralização dos recursos destinados à educação, encarregada de administrar, juntamente com a comunidade, os recursos transferidos às escolas, pelos órgãos federais, estaduais e municipais. É formada por um conselho deliberativo e executivo de pais, diretores e representantes da comunidade, que planeja e fiscaliza a aplicação dos recursos. Foram repassados no período 1997-98 cerca de R\$ 41 milhões para as Caixas Escolares de todo o Estado" (GEA, 2000).
} 
Tabela 06. Número de comunidades que possuem ou participam de organizações sociais e idade média destas organizações.

\begin{tabular}{|c|c|c|c|c|c|c|c|c|c|c|}
\hline $\mathbf{N}^{\circ}$ de Organizações & 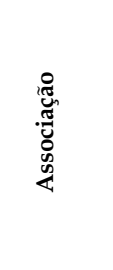 & 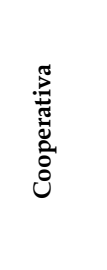 & 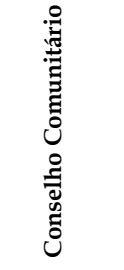 & 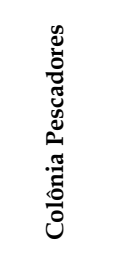 & 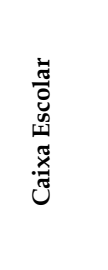 & 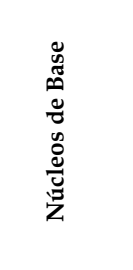 & 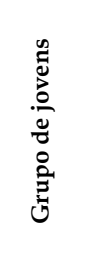 & 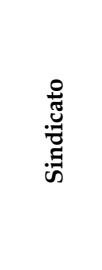 & 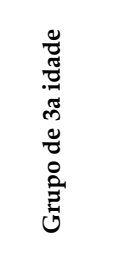 & 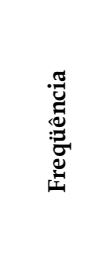 \\
\hline Nenhuma & - & - & - & - & - & - & - & - & - & $16 \%(9)$ \\
\hline Subtotal Nenhuma & & & & & & & & & & $16 \%(9)$ \\
\hline $\begin{array}{l}\text { uma única forma de } \\
\text { organização }\end{array}$ & $x$ & - & - & - & - & - & - & - & - & $\begin{array}{c}44,6 \% \\
(25)\end{array}$ \\
\hline uma & - & $x$ & - & - & - & - & - & - & - & $1,8 \%(1)$ \\
\hline Subtotal Uma & & & & & & & & & & $\begin{array}{c}46,4 \% \\
(26)\end{array}$ \\
\hline $\begin{array}{c}\text { duas formas de } \\
\text { organização }\end{array}$ & $\mathrm{x}$ & $x$ & - & - & - & - & - & - & - & $5,4 \%(3)$ \\
\hline duas & $x$ & - & - & - & - & - & - & $x$ & - & $1,8 \%(1)$ \\
\hline duas & $\mathrm{x}$ & - & - & - & - & $\mathrm{x}$ & - & - & - & $1,8 \%(1)$ \\
\hline duas & $x$ & $x$ & - & - & - & - & - & - & - & $\begin{array}{l}12,5 \% \\
(7)\end{array}$ \\
\hline duas & $\mathrm{x}$ & - & - & - & $x$ & - & - & - & - & $3,6 \%(2)$ \\
\hline Subtotal Duas & & & & & & & & & & $\begin{array}{l}25 \% \\
(14)\end{array}$ \\
\hline $\begin{array}{l}\text { três formas de } \\
\text { organização }\end{array}$ & $x$ & - & - & - & - & - & $\mathrm{X}$ & - & $\mathrm{X}$ & $1,8 \%(1)$ \\
\hline três & $x$ & $\mathrm{x}$ & - & - & - & $\mathrm{X}$ & - & - & - & $1,8 \%(1)$ \\
\hline três & $x$ & $x$ & - & - & - & - & - & $x$ & - & $1,8 \%(1)$ \\
\hline três & $\mathrm{x}$ & - & $\mathrm{x}$ & - & $x$ & - & - & - & - & $1,8 \%(1)$ \\
\hline três & $x$ & - & $x$ & $x$ & - & - & - & - & - & $3,6 \%(2)$ \\
\hline Subtotal Três & & & & & & & & & & $\begin{array}{l}10,7 \% \\
(6)\end{array}$ \\
\hline $\begin{array}{l}\text { quatro formas de } \\
\text { organização }\end{array}$ & $x$ & $x$ & - & $x$ & - & - & $x$ & - & - & $1,8 \%(1)$ \\
\hline Subtotal Quatro & & & & & & & & & & $1,8 \%(1)$ \\
\hline TOTAL & $82 \%(46)$ & $25 \%(14)$ & $5,4 \%(3)$ & $5,4 \%(3)$ & $5,4 \%(3)$ & $3,6 \%(2)$ & $3,6 \%(2)$ & $3,6 \%(2)$ & $1,8 \%(1)$ & \\
\hline $\begin{array}{l}\text { Idade Média } \\
\quad \text { (anos) }\end{array}$ & 5,4 & 5,4 & $\begin{array}{c}\text { sem } \\
\text { informação }\end{array}$ & $\begin{array}{c}\text { sem } \\
\text { informação }\end{array}$ & 3,5 & $\begin{array}{c}\text { sem } \\
\text { informação }\end{array}$ & 1 & 3 & $\begin{array}{c}\text { sem } \\
\text { informação }\end{array}$ & \\
\hline
\end{tabular}

Os entrevistados destas comunidades que não estão envolvidos na administração da organização social local, em sua maioria, declararam não conhecer as atividades que estão sendo desenvolvidas ou limitaram-se a dizer que não estão fazendo nada. A maior parte dos entrevistados envolvidos diretamente em sua administração reclamaram da falta de união, recursos, interesse, visão ou participação dos associados. 
Ou seja só participam os que estão diretamente envolvidos na administração da respectiva associação.

Cerimônias religiosas são as atividades coletivas mais citadas pelos comunitários, em pelo menos $71,4 \%$ das comunidades são as mais importantes. Em alguns casos moradores de comunidades sem igrejas freqüentam as celebrações religiosas em igrejas de comunidades próximas.

Mutirões também são muito freqüentes, 64\% dos entrevistados participam dos mutirões, principalmente para a limpeza de áreas comunitárias, estradas, construção de moradias, reformas na infraestrutura coletiva da comunidade, etc. Reuniões, principalmente organizados pelas associações e cooperativas, vêm em terceiro lugar, com $46 \%$.

Os cultos ocorrem semanalmente, os mutirões em freqüência variável, mas no mínimo anualmente, e as reuniões gerais desde mensal até semestralmente (Figura 18).

Em 12,5\% das comunidades ocorrem também seminários, organizados por órgãos como RURAP, EMBRAPA, SEMA, SEAF, Batalhão Ambiental e outros; com o objetivo de resolver problemas nas associações/cooperativas, passar orientações técnicas sobre diversas atividades (práticas agrícolas, produção de mudas, produção extrativista, práticas de conservação ambiental e combate a incêndios, etc.) e cursos gerais (artesanato, viveiros, manuseio de motosserras, ecoturismo, enxertia, práticas de conservação dos recursos, etc.).

Poucos comunitários citaram a ocorrência de eventos cívicos $(2 \%)$ mas é de se esperar que sejam mais comuns nas comunidades possuidoras de escolas com professores com perfil para estas atividades. Poucos também citaram festas, sendo que algumas comunidades possuem um alto grau de parentesco, esperava-se mais ocorrências. Há também festas de padroeiras religiosas em diversas comunidades, anualmente. Em 12,5\% das comunidades, além de festas e eventuais eventos cívicos, não ocorre nenhuma atividade coletiva (Figura 18). 


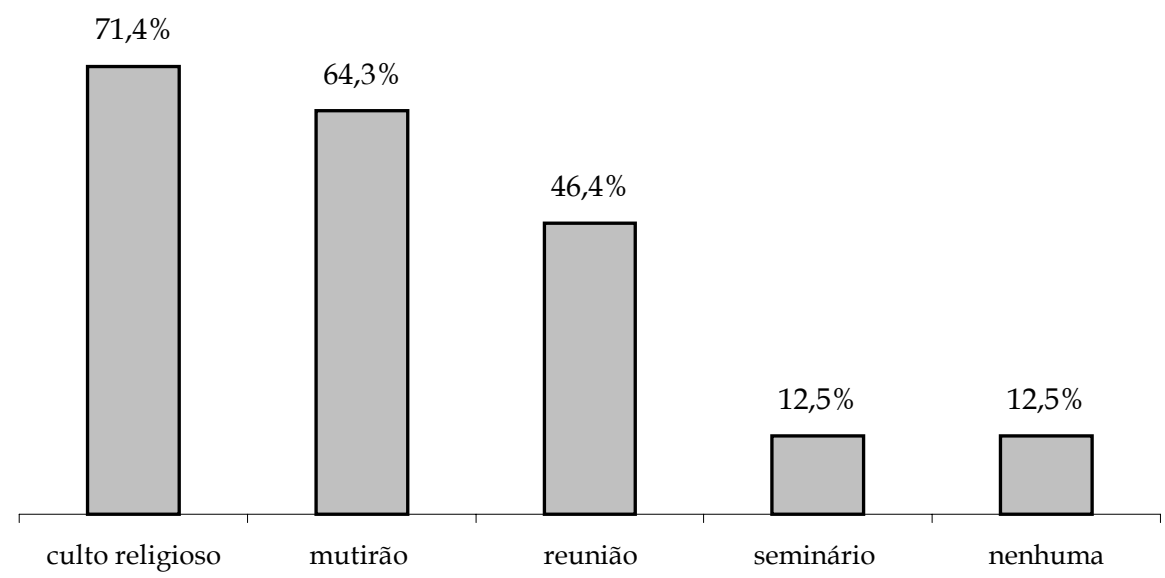

Figura 18 - Atividades coletivas internas das comunidades.

Cerca de $17 \%$ dos entrevistados confirmaram o próprio nome como liderança da comunidade. Estes entrevistado foram justamente procurados por serem reconhecidos como lideranças pelos técnicos do RURAP e FNS.

Vinte e quatro porcento dos entrevistados acreditam que suas comunidades não possuem liderança, ou que os atuais líderes são ineficientes em seus papéis pois tomam decisões equivocadas ou não representativas da vontade dos moradores.

Dos entrevistados que reconhecem alguma liderança na comunidade, $15 \%$ acham que esta pessoa exerce o poder de forma centralizadora, e $85 \%$ acreditam que a exerce democraticamente. É comum comunidades que possuem diversos líderes, mesmo que apenas um tenha sido "eleito" para o cargo pois, os moradores mais antigos e experientes desenvolvem algum tipo de liderança.

Quando os entrevistados que reconhecem lideranças em sua comunidade foram questionados sobre as causas da indicação, 39\% responderam que esta pessoa desenvolvia trabalhos de um típico líder comunitário, lutando pelas causas, fazendo reivindicações e resolvendo problemas gerais da comunidade. Outros 13\% simplesmente porque a pessoa possui "interesse pela comunidade".

Pessoas de trabalho reconhecido em associações/cooperativas locais, simplesmente por serem moradores antigos da comunidade e os "patriarcas" de comunidades pequenas e familiares dividiram outros 31,5\%. Líderes religiosos e 
estimuladores locais da união comunitária receberam 5\% das respostas cada. Outros 5\% são considerados líderes apenas por serem considerados "experientes".

Os principais conflitos que existem nas comunidades são de caráter políticopartidário, normalmente entre famílias disputando a liderança comunitária ou mesmo desencadeado pelo apoio das lideranças a políticos.

Outros problemas comuns são causados pelo uso dos transportes comunitários,de associações ou cooperativas, as feiras para a venda da produção e problemas fundiários em comunidades onde a atividade extrativista e madeireira é importante, alguns proprietários de terrenos superexplorados invadem a terra de vizinhos para a retirada de madeira ou produtos florestais não madeireiros.

Quanto à resolução destes conflitos, $71 \%$ dos entrevistados dizem que é pacifica, com conciliação entre as partes que a iniciaram. A posição da comunidade em evitar o problema, levar ao conhecimento de autoridades e a ausência de conflitos ficaram com $2 \%$ cada. Outros $5 \%$ não deram informações a respeito.

Os $17 \%$ remanescentes acreditam que a conciliação não é alcançada em decorrência de impasses. Este grupo está dividido em 2,5\% que consideram a liderança centralizadora, 5\% acham que não existe liderança e 9,5\% acham que a liderança é ativa e democrática.

A organização social é extremamente importante para o desenvolvimento do manejo florestal comunitário. Nas comunidades caracterizadas esse é um ponto crítico, onde as formas de organizações existentes não possuem maturidade suficiente para o gerenciamento das operações florestais.

Seja qual for o modelo de desenvolvimento, agrícola ou florestal, adotado para as comunidades do Amapá, é imprescindível começar o processo com cursos, oficinas ou outras ferramentas que possam fortalecer a organização social das comunidades. Somente com a sociedade fortalecida, conhecendo seus direitos e deveres, e organizada as iniciativas de desenvolvimento podem obter sucesso. 


\subsubsection{Fontes de renda}

Os produtos de subsistência das comunidades não foram objeto desse levantamento, mas sim os excedentes da produção agropecuária e extrativista.

Todas as comunidades utilizam a agricultura e o extrativismo, e uma grande parte delas também criam animais, ao menos para subsistência. O arroz, mandioca, milho, feijão, banana, cupuaçu, açaí (palmito e frutos), o pescado (na região da várzea e arquipélago do Bailique) e com certa freqüência porcos, galinhas, patos e cabras são produtos típicos na maioria das comunidades. A madeira é extraída ao menos para consumo em cocção e em construções.

\subsubsection{Atividades econômicas das comunidades de terra firme}

Nas comunidades estabelecidas em "terra firme", a principal atividade econômica é a agricultura (para 40\% das comunidades destas regiões), sendo praticada em quase $90 \%$ delas. O principal produto comercializado é a farinha de mandioca, seguida pela banana, milho, feijão, mandioca, cupuaçu. A produção e excedentes são comercializadas nas cidades, utilizando principalmente os transportes municipais e estaduais de produtores, caminhões das associações e cooperativas. Localmente existe a comercialização interna de produtos, mas é pequena (Figuras 14 e 15).

O extrativismo é a principal atividade econômica em $20 \%$ das comunidades, e acontece em 60\% delas. Os principais produtos são açaí (principalmente o fruto), castanha e em menor quantidade o látex, cipós e óleos de andiroba e copaíba. O destino dos produtos extrativistas pode ser o mesmo dos da agricultura ou comercializados por intermédio de associações e/ou cooperativas (destacando-se o látex e a castanha).

Quase 20\% das comunidades de terra firme tem ainda como principal atividade econômica a madeira, geralmente desdobrada com motosserra e vendida a outros comunitários e até mesmo nas cidades, e 20\% a carvoaria. Estas atividades são praticadas em $36 \%$ e $20 \%$ das comunidades de terra firme, respectivamente. Outras fontes de renda incluem a criação de animais (36\%) e movelaria (4\%). 


\subsubsection{Atividades econômicas das comunidades de várzea.}

A principal atividade econômica da várzea é a atividade madeireira, em 53,8\% das comunidades entrevistadas nestas regiões. Consideramos nesta categoria tanto a renda obtida por comunitários na venda da madeira quanto a obtida por donos de serrarias locais. A atividade madeireira é praticada em $67 \%$ das comunidades de várzea visitadas (e será melhor discutida no item “4.3.12 Produção Florestal”).

A segunda atividade econômica mais importante da várzea é o extrativismo (38,5\% das comunidades), sendo o principal produto o fruto do açaí (extraído em 92\% das comunidades locadas na várzea). O palmito já foi um produto muito explorado e ainda vem sendo, mas atingiu patamares menos elevados devido às restrições legais (a criação da RESEX do rio CaJarí para as comunidades locadas em seu interior, por exemplo), trabalhos de conscientização/fiscalização do IBAMA e do Batalhão Ambiental e mesmo a menor abundância, no momento, deste recurso.

A pesca, ainda, é a atividade mais importante para 7,7\% das comunidades, e é praticada em $54 \%$ das comunidades de várzea. Tanto os produtos extrativistas como o pescado são vendidos diretamente nas cidades próximas (Macapá e Santana) ou a atravessadores locais (Figuras 19 e 20).

O fruto do açaí é o produto mais conhecido e preferido das comunidades de várzea do Amapá. Dentro da RESEX do Rio Cajarí, por exemplo, produtores estão se cadastrando para obter o financiamento do PRODEX visando o plantio/manejo de açaizais. Porém, muitos entrevistados se queixaram da falta de compradores e baixos preços obtidos na sua venda, fatores que estimulariam a procura de novas fontes econômicas, onde madeira e palmito, foram as mais citadas.

Mesmo nas comunidades onde o fruto do açaí é a principal fonte de renda, nos meses da entressafra há uma forte procura na obtenção de renda através da venda da madeira e do palmito de açaí. No caso do palmito cria-se um ciclo vicioso insustentável, onde quando não se produz o fruto a planta é cortada para a produção do palmito e a 
preocupação com o manejo de açaizais para que só sejam cortados os indivíduos mais velhos não foi encontrada, prejudicando assim a próxima safra de frutos.

Outras atividades econômicas das comunidades de várzea são a agricultura de subsistência, presente em $79 \%$ das comunidades, criação de animais em $58 \%$ e olarias em $4 \%$.

\subsubsection{Atividades econômicas das comunidades do Arquipélago do Bailique}

As maiores fontes de renda da região são a pesca em 33,3\% das comunidades e o extrativismo. Neste caso também são principais produtos o fruto e palmito do açaí $(33,3 \%)$. O pescado e o fruto do açaí são vendidos em Macapá ou para atravessadores locais.

Há quatro fábricas de processamento do palmito em atividade no arquipélago, sendo estas são as principais compradoras do produto extraído na região ${ }^{3}$.

O extrativismo e a pesca são praticados em $100 \%$ e $86 \%$ das comunidades da região do arquipélago do Bailique, respectivamente. Uma série de comunitários esperam desenvolver a produção do fruto do açaí através de projeto do FRAP, viabilizado pelo RURAP, para manejo de açaizais.

A agricultura e a bubalinocultura são as principais fontes de renda em 16,7\% das comunidade da região cada. A criação de animais em geral e a agricultura são praticadas em $86 \%$ destas comunidades. Os produtos são comercializados localmente ou em Macapá.

A exploração madeireira, embora não seja a principal atividade nas comunidades do Bailique, é realizada em $71 \%$ delas. É também, das três regiões estudadas, a que mais possui comunidades dedicadas à agregação de valor ao material: estaleiros em $29 \%$ das comunidades visitadas e movelarias em $14 \%$.

A apicultura está presente em 29\% das comunidades amostradas (Figuras 19 e 20).

\footnotetext{
${ }^{3}$ João da Cunha Mourão Neto. técnico da SEAF. Comunicação pessoal, 2000.
} 


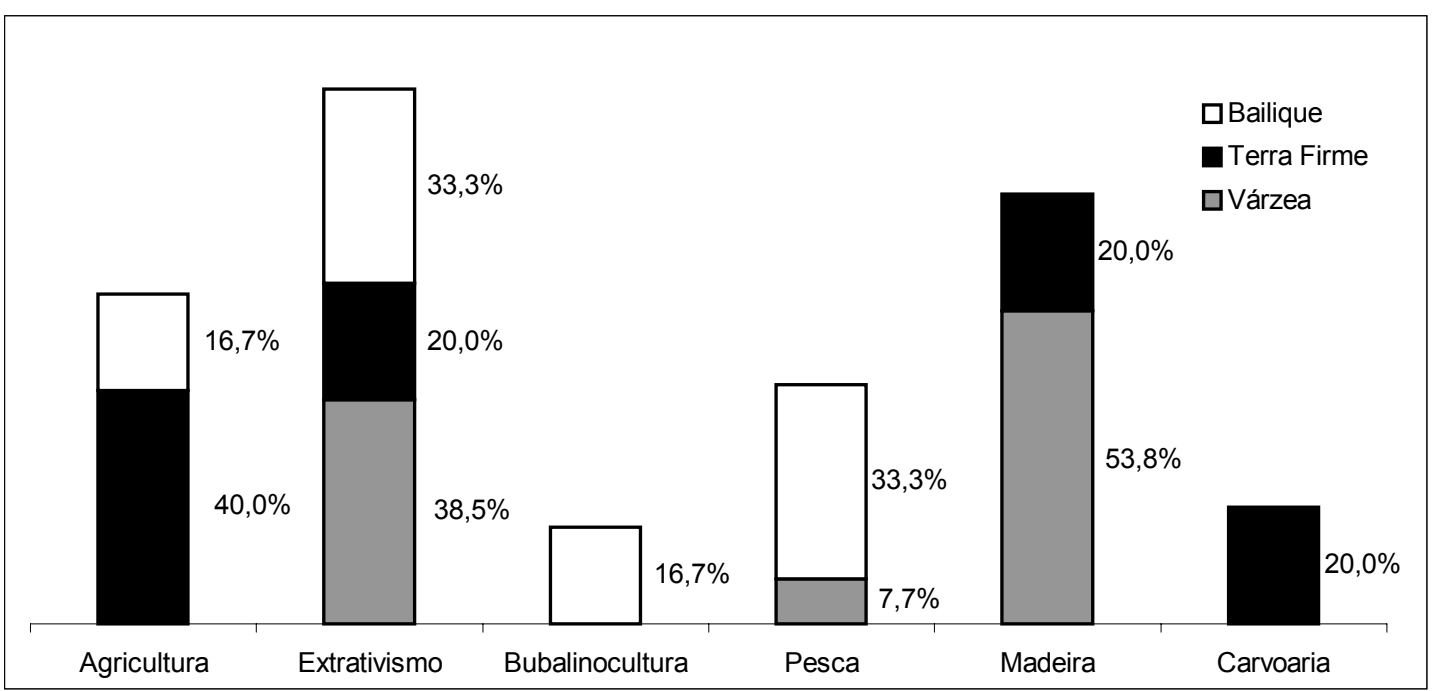

Figura 19 - Freqüência das principais atividades econômicas das comunidades por região de amostragem.

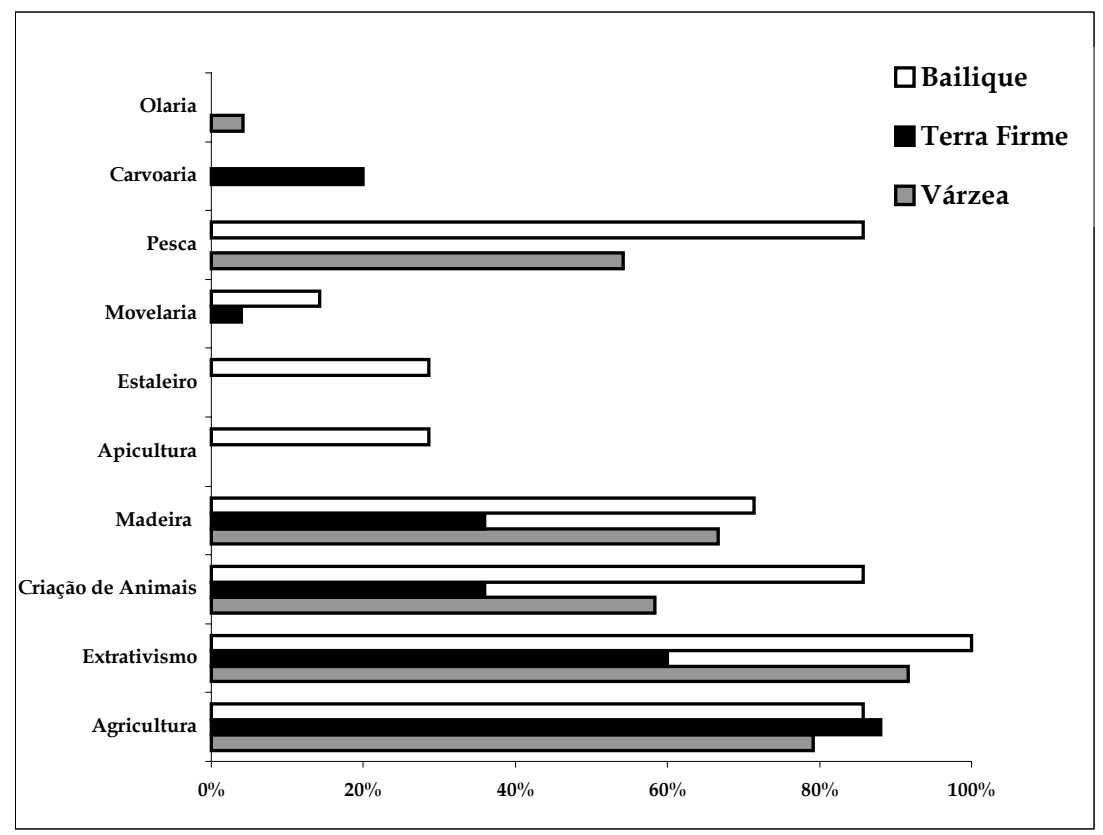

Figura 20 - Freqüência das atividades econômicas das comunidades por região de amostragem.

\subsubsection{Fontes externas de renda.}

Apenas 16\% dos entrevistados declararam possuir alguma fonte de renda externa à comunidade (Figura 21). Destes, 44\% por serem funcionários públicos, 25\% 
através de aposentadoria, $18,8 \%$ por auxílio externo, 6,3\% através de aluguel de casas em outros locais e 6,3\% através de emprego. Esta situação demonstra que a formação de renda dos comunitários depende de atividades que precisam ser desenvolvidas na própria comunidade. O Manejo Florestal Comunitário pode ser uma importante fonte de renda para os comunitários.

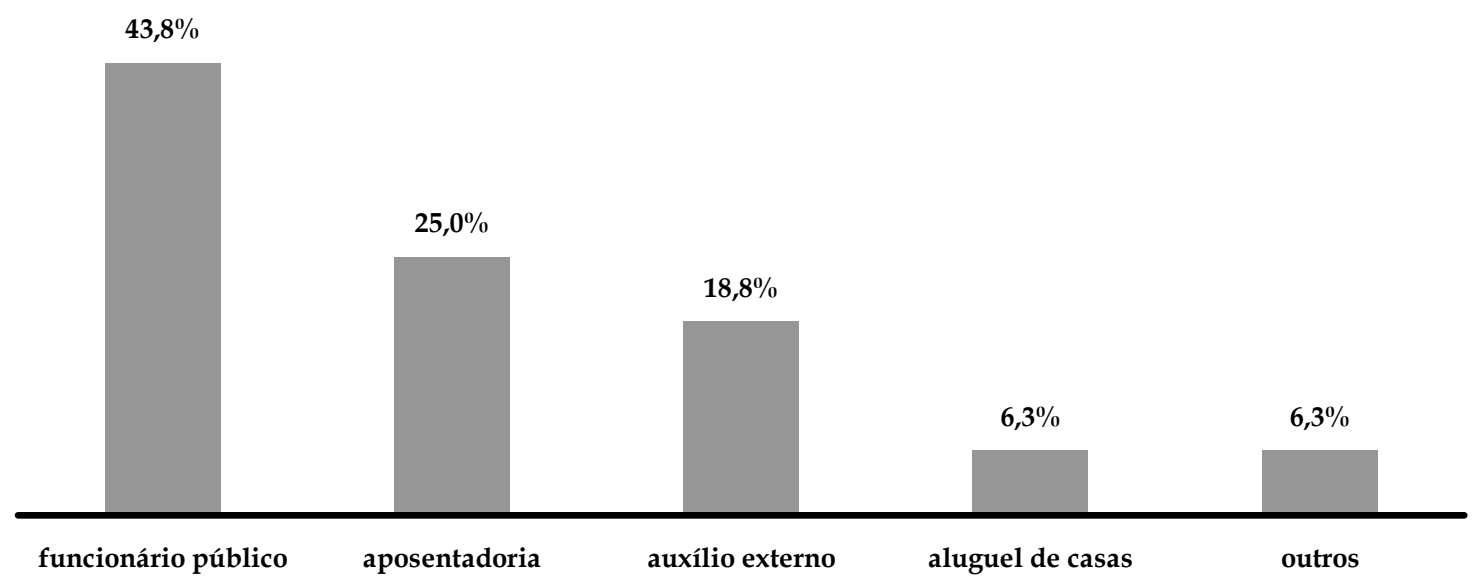

Figura 21 - Tipos de fonte de renda externas à comunidade.

\subsubsection{Escolaridade e Idade}

Dos comunitários com idade entre 21 e 40 anos, a maior parte $(37 \%$ das mulheres e $28 \%$ dos homens) possui $1^{\underline{0}}$ grau incompleto. Minorias $(1,7 \%$ das mulheres e $1,2 \%$ dos homens) possuem o $2^{\underline{0}}$ grau completo ou nenhuma escolaridade (3\% e 5,5\%, respectivamente). Mais de $54 \%$ da população adulta nesta faixa de idade é masculina (Figura 22).

Para a faixa de etária entre 40 e 60 anos, a maior parte dos homens só possui parte do primário ( $25,6 \%$ do total de homens inseridos nessa faixa etária) e a maior parte das mulheres, nenhuma escolaridade (21,6\% do total de mulheres inseridas nessa faixa etária). Uma pequena parte destes comunitários pôde freqüentar a escola até o final do $1^{\circ}$ grau ( $2 \%$ das mulheres e $3 \%$ dos homens). Observa-se nesta faixa etária um aumento de 
analfabetos, constituindo quase $37 \%$. Os homens são maioria nesta faixa etária, $55 \%$ do total nesta faixa etária (Figura 23).

Segundo os dados oficiais do Governo do Estado 48\% da população do estado está matriculado, em escolas públicas ou privadas, e o índice de analfabetismo caiu de quase 13\%, no ano de 1993, para 9,5\% em 1999 (Governo do Estado do Amapá, 2001). Os dados do Tribunal de Justiça do Amapá colocam que o analfabetismo estava em 12,98\% no ano de 1996 (Tribunal de Justiça do Amapá, 2001).

Para as pessoas próximas ou dentro da terceira idade (acima de 60 anos), não existe nenhum representante com algum grau de escolaridade. A porcentagem de mulheres nesta faixa é ainda menor, $49 \%$.

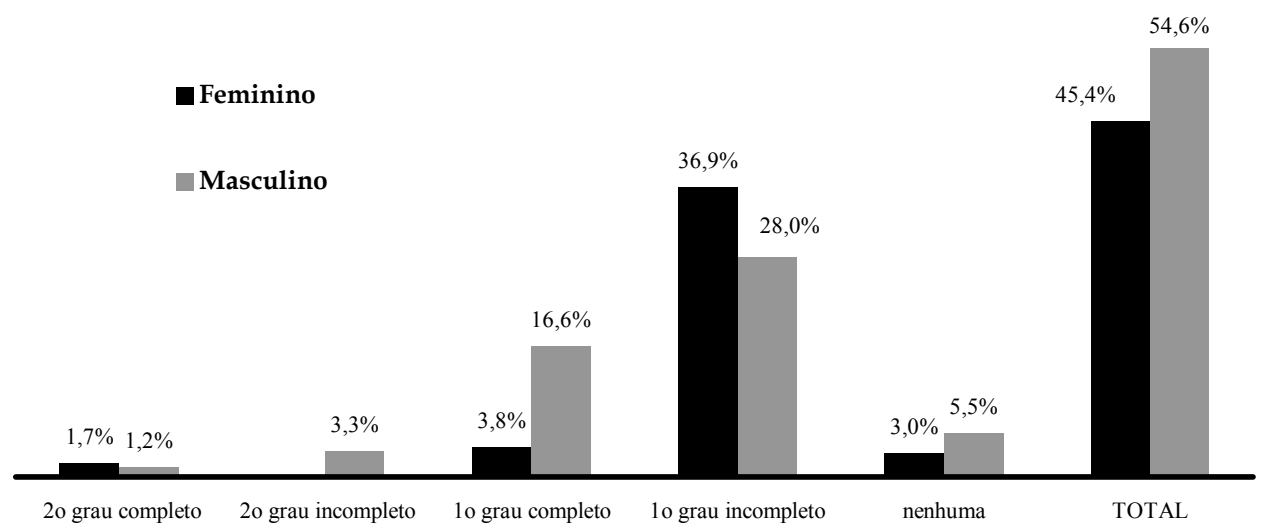

Figura 22 - Escolaridade dos comunitários de 21 a 40 anos de idade.

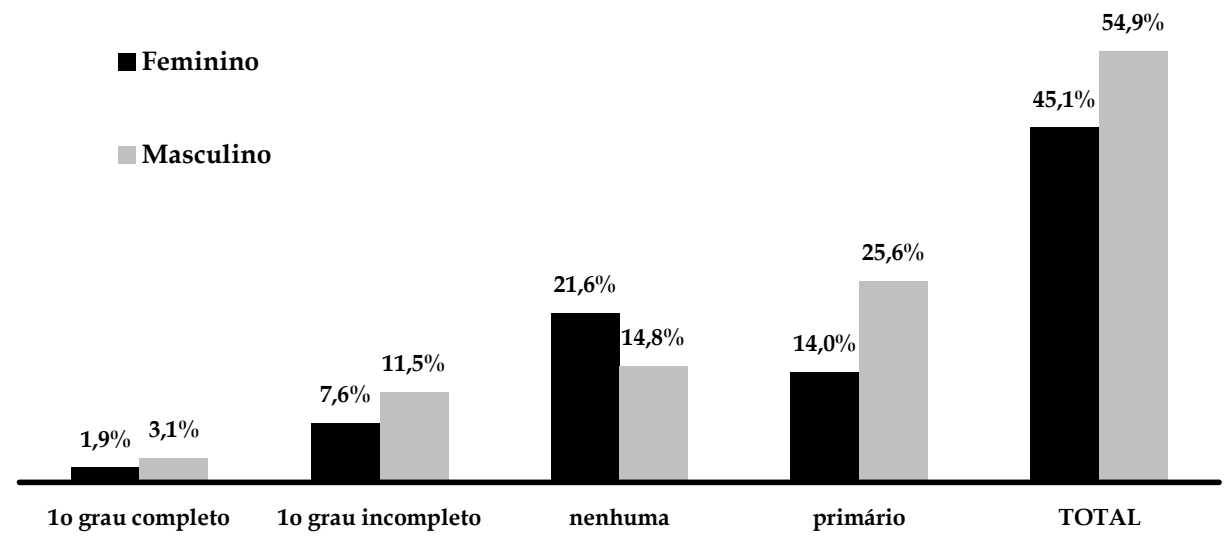

Figura 23 - Escolaridade dos comunitários de 41 a 60 anos de idade. 
Cinqüenta e cinco porcento (55\%) dos entrevistados participaram de algum tipo de curso ou treinamento. Os órgão responsáveis pelos cursos ministrados aos comunitários são o RURAP (43\% dos casos), SENAR (30\%), CNPT/IBAMA (11\%, dentro da RESEX do Rio CaJarí), IEPA (8\%); REBRAF e SEBRAE (5\% das respostas cada). Foram também citados: a Igreja Católica, IBAMA, Jarí Celulose, POEMA, FAOR, Capitania dos Portos, Conselho Comunitário do Bailique, SEMA, SEPLAN, SEAF, EMBRAPA e TERRAP (2,7\% das respostas cada). Vários entrevistados participaram de mais de um curso.

Os cursos e treinamentos tem duração variada, desde alguns dias até um mês (em média os entrevistados tiveram 15 dias de treinamento). Alguns entrevistados e líderes comunitários declararam repassar os conhecimentos adquiridos, principalmente quando estes cursos são oferecidos em cidades próximas e nem todos os comunitários podem participar, mas uma boa parte $(25 \%)$ destes cursos foram ministrados nas próprias comunidades.

Dos cursos ministrados, segundo os entrevistados, $27 \%$ versaram sobre culturas agrícolas e tratos culturais, cerca de $18 \%$, sobre técnicas de manuseio, segurança e trabalho com motosserras. Culinária e conservação de alimentos, 16\%. Piscicultura, plantas medicinais e técnicas de viveiros de mudas ficaram com $9 \%$ das respostas cada. Segue-se os treinamentos para agente comunitário de saúde e manejo de rebanhos e bubalinocultura ( $7 \%$ cada).

Poucos entrevistados participaram de cursos em outras áreas diversas, que vão desde aos afazeres domésticos (corte e costura/crochê) até alternativas econômicas (apicultura, extrativismo, SAF's, pesca, movelaria), informática, prevenção de doenças e outros (Tabela 06). Cursos importantes para a organização social, como curso de lideranças $(5,5 \%)$, cooperativismo $(5,5 \%)$, núcleos de base $(5,5 \%)$, gerenciamento $(3,6 \%)$, organização social comunitária $(1,8 \%)$ e políticas públicas $(1,8 \%)$ foram pouco oferecidos para as comunidades.

Capacitação técnica e organização social são pontos importantes para o manejo florestal. O governo do Estado não pode atender com qualidade todas essas demandas, assim deveria criar, através de convênios ou outros instrumentos, condições para que 
instituições especializadas possam assumir o problema da educação formal e também as de especialização, onde os treinamentos para agricultura e produção florestal poderiam ser direcionados para as reais necessidades das comunidades.

Tabela 7. Assunto dos cursos ministrados.

\begin{tabular}{|c|c|}
\hline Assunto dos Cursos & Porcentagem dos Entrevistados \\
\hline culturas agrícolas/tratos culturais & $27,3 \%(15)$ \\
\hline manuseio e técnicas de motosserra & $18,2 \%(10)$ \\
\hline culinária/conservação de alimentos & $16,4 \%(9)$ \\
\hline piscicultura & $9,1 \%(5)$ \\
\hline plantas medicinais & $9,1 \%(5)$ \\
\hline técnicas e tratos em viveiros de mudas & $9,1 \%(5)$ \\
\hline agente comunitário de saúde & $7,3 \%(4)$ \\
\hline manejo de rebanhos/bubalinocultura & $7,3 \%(4)$ \\
\hline artesanato & $5,5 \%(3)$ \\
\hline cooperativismo & $5,5 \%(3)$ \\
\hline corte e costura & $5,5 \%(3)$ \\
\hline formação de lideranças & $5,5 \%(3)$ \\
\hline núcleos de base & $5,5 \%(3)$ \\
\hline seringais (manejo, beneficiamento) & $5,5 \%(3)$ \\
\hline formação técnica & $5,5 \%(3)$ \\
\hline agente de defesa ambiental & $3,6 \%(2)$ \\
\hline apicultura & $3,6 \%(2)$ \\
\hline combate a incêndios & $3,6 \%(2)$ \\
\hline extrativismo (beneficiamento, manejo de áreas) & $3,6 \%(2)$ \\
\hline gerenciamento & $3,6 \%(2)$ \\
\hline técnica, manejo e beneficiamento de pescado & $3,6 \%(2)$ \\
\hline formação religiosa & $3,6 \%(2)$ \\
\hline Sistemas Agroflorestais & $3,6 \%(2)$ \\
\hline crochê & $1,8 \%(1)$ \\
\hline couro ecológico & $1,8 \%(1)$ \\
\hline informática & $1,8 \%(1)$ \\
\hline movelaria/serraria/carpintaria & $1,8 \%(1)$ \\
\hline organização social comunitária & $1,8 \%(1)$ \\
\hline políticas públicas & $1,8 \%(1)$ \\
\hline prevenção de doenças & $1,8 \%(1)$ \\
\hline TOTAL & $100 \%(55)$ \\
\hline
\end{tabular}




\subsubsection{Situação fundiária}

Em 28,6\% das comunidades, encontrou-se entrevistados que não possuíam nenhum documento fundiário. $\mathrm{O}$ documento fundiário mais freqüente nas famílias das comunidades visitadas é a Licença de Ocupação do INCRA (27\% dos casos), seguido pelo Título Definitivo/Escritura (25\%), contrato de concessão de uso expedido pelo CNPT/IBAMA (16\%), declaração de posse ou declaração de ocupação expedido pelo INCRA (16\%), cadastro de ocupação ou de posse do INCRA (9\%) e Licença de Ocupação do TERRAP (7\%) (Tabela 08).

Uma minoria possui o contrato de concessão de uso do INCRA e declaração de ocupação ou posse do CNPT/IBAMA (5,4\% cada), carta de anuência, CPCV-TERRAP, documento de compra e venda, título de ocupação do INCRA e título de posse do INCRA $(1,8 \%$ cada).

Praticamente os únicos documentos que são expedidos hoje a pequenos proprietários posseiros em áreas da União são o contrato de concessão de uso e o título definitivo, dependendo da demarcação das terras ter sido ou não realizada. Outras dificuldades também são encontradas pelos proprietários na obtenção do título definitivo, como a falta de documentos pessoais, principalmente o $\mathrm{CPF}^{4}$.

Já os beneficiários de programas de reforma agrária recebem um título de reforma agrária que para efeito de licenciamento ambiental para o manejo florestal já é suficiente, já que o IBAMA reconhece para fins de aprovação do plano de manejo todos os documentos reconhecidos e concedidos pelo INCRA. Ainda segundo o técnico do INCRA, a prioridade atual do órgão é a reforma agrária, mais exatamente a etapa de desapropriação de áreas, seguida da regularização fundiária, principalmente dos pequenos proprietários (até 100 ha). Em áreas privadas, o governo tende a não legitimar a posse, a menos que haja desapropriação para fins de reforma agrária ${ }^{5}$.

\footnotetext{
${ }^{4}$ Antonio Carlos Cruz, INCRA. Comunicação pessoal, 2000

${ }^{5}$ José Benatti. Comunicação pessoal, 2000.
} 
Tabela 8. freqüência dos diferentes documentos fundiários encontrados.

\begin{tabular}{cc}
\hline Documento Fundiário & $\mathrm{N}^{\circ}$ de Comunidades \\
\hline nenhum & $28,6 \%(16)$ \\
licença de ocupação/INCRA $^{6}$ & $26,8 \%(15)$ \\
título definitivo $^{7}$ & $25,0 \%(14)$ \\
contrato de concessão de uso/CNPT $^{8}$ & $16 \%(9)$ \\
declaração de ocupaçao/posse INCRA $^{9}$ & $16 \%(9)$ \\
cadastro de ocupação/posse INCRA $^{10}$ & $8,9 \%(5)$ \\
licença de ocupação/TERRAP & $7,1 \%(4)$ \\
contrato de concessão de uso/INCRA & $5,4 \%(3)$ \\
declaração de ocupaçao/posse CNPT & $5,4 \%(3)$ \\
carta de anuência ${ }^{11}$ & $1,8 \%(1)$ \\
CPCV/TERRAP & $1,8 \%(1)$ \\
documento de compra e venda & $13 \%(1)$ \\
título de ocupação/INCRA & $1,8 \%(1)$ \\
título de posse/INCRA & $1,8 \%(1)$ \\
\hline
\end{tabular}

${ }^{6}$ A Lei federal 6383, de dezembro de 1976, dispõe sobre o processo discriminatório de Terras Devolutas da União, legitimando a posse de áreas familiares até 100 ha através da Licença de Ocupação, intransferível e inegociável pelo prazo mínimo de 4 anos. Findo este prazo, o ocupante tem preferência na aquisição do lote pelo valor histórico da terra nua, desde que satisfeitos os requisitos de morada permanente na área, cultura efetiva pelo prazo mínimo de 1 ano e não possuir outro imóvel rural. A Lei assegura também acesso a financiamentos de instituições integrantes do Sistema Nacional de Crédito Rural. Caracteriza a justa posse de terras, sendo necessária a demarcação das áreas para que os ocupantes adquiram o título definitivo.

${ }^{7}$ Título que torna o possuidor proprietário legal da terra

${ }^{8}$ O Decreto Lei $98.897 / 90$ reza que, a exploração extrativista fica regulada por Contrato de Concessão Real de Uso, concedida a associação ou cooperativa extrativista. O direito real de uso da terra será, ainda, concedido gratuitamente $\left(\right.$ Art. $\left.4^{\circ}, \S 1^{\circ}\right)$.

${ }^{9}$ Documentos cedidos pelo INCRA em áreas públicas/devolutas para posseiros, que deveriam preencher certos requisitos, como vocação à agricultura, para obter um título definitivo. Caso os posseiros quisessem adquirir financiamento, o órgão expedia uma Carta de Anuência (José Benatti. Comunicação pessoal, 2000).

${ }^{10}$ Cadastro de ocupantes de terras públicas e devolutas feito por órgão fundiário para medidas posteriores de regularização. Segundo (Incra, comunicação pessoal), sua aquisição é feita mediante uma simples declaração do ocupante, que o torna passível da cobrança do ITR, embora não lhe ceda o domínio ou propriedade sobre a terra (José Benatti. IPAM. Comunicação pessoal, 2000. Antonio Carlos Cruz. INCRA. Comunicação pessoal, 2000).

${ }^{11}$ Documento fornecido pelo órgão fundiário reconhecendo a posse da área por determinado lavrador.

${ }^{12}$ Contrato Provisório de Compra e Venda. Durante o processo de regularização fundiária junto ao TERRAP, é realizado durante determinado período o pagamento da terra. Finda a quitação, é interesse do proprietário solicitar a demarcação de suas terras, para a obtenção do título definitivo. As despesas topográficas e de mão de obra do processo de demarcação correm por conta do proprietário (Mauro Montoril, SEAF. Comunicação pessoal, 2000).

${ }^{13}$ Documento possessório de transação comercial entre um posseiro e outro, podendo até ter sido firmado em cartório. Entretanto, a terra não é legitimada neste processo, não havendo um direito real (domínio) do ocupante sobre a terra (José Benatti, IPAM. Comunicação pessoal, 2000)

${ }^{14}$ Título de terra não definitivo entregue a trabalhador rural.

${ }^{15}$ Título concedido por órgãos fundiários de ação estadual para explorar a terra. 
Aproximadamente $21 \%$ dos entrevistados estão na região de várzea e não possuem nenhum documento. Se estas famílias estiverem locadas em terras de marinha (ver 7.2), a regularização fundiária poderá ser realizada apenas pela Delegacia do Patrimônio da União (DPU), que expedirá um contrato de concessão de uso aos ocupantes, que por sua vez deverão pagar pelo seu uso. Os posseiros nestas áreas jamais poderão se tornar legítimos proprietários das terras.

Existem dúvidas hoje a respeito de quais documentos fundiários podem ser considerados como comprovantes da justa posse de pequenas extensões de terras (até 100 ha). A Instrução Normativa 06 do IBAMA, de 28/12/1998, que dispõe sobre a exploração e o manejo florestal em escala empresarial na região amazônica, lista os documentos que caracterizam justa posse de terra para áreas acima de 500 ha. Entre eles, estão: (i) a licença de ocupação; (ii) o título definitivo; (iii) a carta de anuência; (iv) o contrato de concessão de uso de terras públicas e de domínio de terras públicas; (v) a concessão de direito real de uso, e (vi) o título de domínio (ver 7.2).

No caso do manejo florestal comunitário, o IBAMA reconhece todos os títulos expedidos ou reconhecidos pelo INCRA dando a posse, propriedade ou direito de uso ao cidadão que solicita a aprovação do plano de manejo florestal comunitário, desde que a área total do empreendimento não ultrapasse 500 ha por família envolvida no projeto.

Um importante ponto a ser analisado pelo Governo do Estado é a falta de interesse dos ocupantes de pequenas áreas em regularizá-las. Se não há o interesse ou mesmo a possibilidade de obter financiamentos ou acessar novos mercados a regularização acaba sendo pouco interessante ${ }^{16}$.

Um dos fatores que colaboram para esta situação é a obrigatoriedade do pagamento das terras pelos ocupantes no processo de regularização. A Instrução Normativa Incra 41/2000 reza que, "no caso de legitimação de posse, o valor cobrado será definido em tabela de acordo com o valor histórico do imóvel". Em terras do programa de reforma agrária, este valor será "pago em prestações anuais com prazo de

\footnotetext{
${ }^{16}$ José Benatti. IPAM. Comunicação pessoal, 2000; Antonio Carlos Cruz. INCRA. Comunicação pessoal, 2000
} 
amortização de até 20 anos, incluída a carência de 3 anos, incidindo correção monetária a partir da data da emissão do título até a data do pagamento".

Além disso, freqüentemente as famílias ocupantes possuem áreas maiores do que as contempladas em seus documentos fundiários. No processo de demarcação, estas famílias perdem parte das áreas onde possuem efetivamente a posse, que poderão ser cedidas a outras famílias. Do ponto de vista cultural, a relação fundiária histórica do país foi baseada na posse de terra. Técnicos do INCRA reconhecem que é pequena a probabilidade de posseiros em terras públicas virem a perder as suas áreas, o que só ocorreria oficialmente mediante desapropriação ${ }^{17}$.

Com o incentivo ao manejo florestal, as famílias detentoras das terras poderiam se motivar também a procurar a legalização de suas áreas, já que a posse legal da terra é exigida pelo IBAMA. O manejo florestal ao mesmo tempo que representa mais uma fonte de renda para as famílias pode também representar a viabilização econômica do pagamento dessas terras, que acontece depois da legalização. O governo poderia ganhar duplamente com isso, através da produção comercial e da regularização fundiária do Estado.

Para as comunidades visitadas a melhor opção seria o Manejo Florestal em Pequena Escala e não o Comunitário. O manejo florestal comunitário possui características muito particulares, como a principal que é a posse comum da terra ou da área a ser manejada. No caso do Amapá as comunidades já estão explorando, de forma comunitária ou não, a floresta na propriedade de cada família.

Para o Amapá o melhor seria o desenvolvimento de atividades de Manejo Florestal em Pequena Escala com Serrarias Comunitárias. Este modelo pode ser implantado com maior facilidade já que não implica na negociação, sempre desgastante, da cessão de áreas particulares para a exploração em comum. As famílias continuariam soberanas em suas propriedades, e as atividades de exploração poderiam ser realizadas por cada proprietário, sendo comum somente os equipamentos.

No caso de famílias que não possuem área para o manejo, poderiam ser devidamente treinadas em técnicas de manejo e serraria, podendo assim fornecer serviços 
para as famílias que não possuem pessoal suficiente ou não desejam realizar essas atividades. As Serrarias Comunitárias e os equipamentos para a exploração florestal, poderiam ser financiadas pelo governo para uma dada comunidade, e seriam o fator comunitário em torno da atividade florestal.

\subsubsection{Evolução do uso da terra}

De uma maneira geral, as áreas onde estão inseridas as comunidade possuem ainda um grande percentual de florestas, sejam de terra firme, de várzea ou mesmo áreas já exploradas.

A denominação "florestas pouco exploradas", aqui utilizada, se refere a áreas onde já foram realizadas atividades extrativistas e madeireiras, para consumo interno das comunidades. As florestas pouco exploradas referem-se, portanto, às áreas que sofreram algum tipo de intervenção humana e exploração extensiva, mas com vocação para projetos de manejo florestal. Já a denominação "florestas muito exploradas" é onde explicitamente estas atividades econômicas já foram realizadas, de uma forma mais intensa.

Há grandes semelhanças entre os tipos de cobertura das áreas comunitárias em terra firme e várzea (Tabela 9). Mais de $60 \%$ das áreas são cobertas pelas "florestas pouco exploradas". Na várzea, $19 \%$ são várzeas inundáveis, $8 \%$ são pastos e $6 \%$ das áreas são divididas entre florestas muito exploradas e capoeiras. Há pequenas porcentagens de igapós, açaizais nativos, culturas permanentes e roças. Na terra firme, $18 \%$ são capoeiras, $6 \%$ são culturas permanentes e $4 \%$ são florestas muito exploradas. Algumas poucas áreas são destinadas às roças, pastos e campos, além de várzeas inundáveis nas proximidades de rios.

${ }^{17}$ Antonio Carlos Cruz. INCRA. Comunicação pessoal, 2000. 
Tabela 9. tipos de cobertura vegetal citadas pelas comunidades.

\begin{tabular}{ccc}
\hline Cobertura vegetal & Áreas de Várzea (\%) & Áreas de Terra Firme (\%) \\
\hline florestas pouco exploradas & $60,9 \%$ & $65,9 \%$ \\
várzea inundável & $18,8 \%$ & $1,5 \%$ \\
capoeiras & $3,3 \%$ & $17,8 \%$ \\
pastos & $7,9 \%$ & $2,5 \%$ \\
culturas permanentes & $2,3 \%$ & $5,5 \%$ \\
florestas muito exploradas & $2,8 \%$ & $4,4 \%$ \\
roça & $2,4 \%$ & $1,7 \%$ \\
açaizal nativo & $0,7 \%$ & - \\
campos & - & $0,7 \%$ \\
igapós & $0,8 \%$ & - \\
TOTAL & $100,0 \%$ & $100,0 \%$ \\
\hline
\end{tabular}

Essas áreas não foram levantadas com um sistema de informação geográfica. Os tamanhos das áreas foram obtidos através das entrevistas com a ajuda de um mapa, confeccionado no momento da entrevista sob a orientação do entrevistado, portanto são dados ilustrativos originados do conhecimento aguçado dos limites das propriedades dos entrevistados e da área comum da comunidade, mas não são precisos.

Muitas áreas de florestas e outros tipos de cobertura naturais destas regiões começaram a ser exploradas entre 21 e 30 anos atrás (29\%). Outra grande parcela das comunidades iniciou o processo de 11 a 20 anos atrás (21\%). Explorações iniciadas recentemente ( 2 a 5 anos atrás) e muito antigas (há mais de 1 século) aconteceram em apenas 7\% das comunidades (Figura 24).

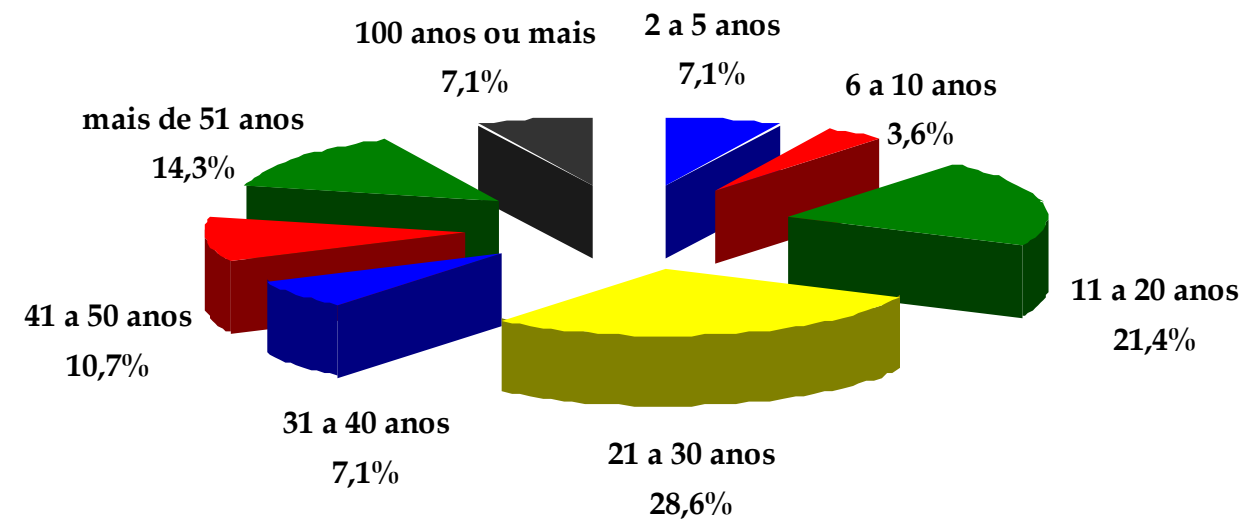

Figura 24 - Tempo de exploração das florestas pelas comunidades. 
Acompanhando as 14 principais experiências de manejo florestal comunitário na Amazônia podemos afirmar que o modelo adotado privilegia a conservação dos recursos florestais, na medida que as necessidades de lucro de uma iniciativa familiar é infinitamente menor do que a de uma empresa, e além disso soma-se ainda o fato de que a renda familiar é diversificada, sendo formada pela comercialização de mais de um produto.

Acreditamos que o Manejo Florestal em Pequena Escala também possa ser tão conservacionista quanto o Manejo Florestal Comunitário, já que parte dos mesmo princípios de lucro, e onde a educação ambiental e para a autogestão do empreendimento é um ponto importante para a sucesso/sustentabilidade dos dois modelos de administração.

No caso dos assentamentos em áreas florestais promovidas pelo INCRA, fica ainda mais evidente as vantagens para a conservação florestal apresentadas pelo modelo de desenvolvimento regional através do Manejo Florestal em Pequena Escala. Através dele os assentados podem possuir uma fonte de renda durável e muito mais digna do que as alternativas que hoje lhes restam. Queimar a floresta para fazer carvão, na tentativa de um dia viabilizar a agricultura, simplesmente prolonga a condição de sub-emprego dos assentados. São proprietários mas não produtores!

Vendendo sua força de trabalho e os recursos florestais de suas propriedades, só conseguirão viabilizar por mais tempo sua estada naquele lote, retardando a venda da terra e a conseqüente migração para outra fronteira de reforma agrária. $\mathrm{O}$ assentado, depois de ter todo seu lote transformado em carvão, volta para a periferia das cidades ou para um novo acampamento a espera de um novo lote para novamente repetir os mesmos erros. Definitivamente esta forma de "desenvolvimento" não pode mais ser replicada na Amazônia.

O manejo florestal para a produção de produtos com maior valor agregado, como simples tábuas, é uma alternativa economicamente mais viável do que a substituição da floresta pela agricultura extensiva que, durante anos vem acumulando mais fracassos do que sucessos na Amazônia. 
Em áreas onde o assentamento está localizado dentro do raio de alcance da atividade madeireira, os assentados possuem mais uma opção. No caso de não se interessarem pelo processamento primário da madeira, a venda de toras para os madeireiros. No Estado do Amapá, não nos deparamos com esta situação mas na região de Marabá, Estado do Pará, os assentados vendiam árvores inteiras por somente R $\$ 15$, 00 (US\$ 7). Hoje processando a tora estão vendendo tábuas por valores muito maiores, que variam de acordo com a espécie, mas mesmo as mais "desvalorizadas" ainda rendem muito mais do que a venda de toras.

Mas o modelo acima não deve ser desprezado, pois em casos como o manejo florestal em terra indígena, onde os índios não se interessaram em realizar as atividade de corte e processamento, tem mostrado bons resultados. A administração do projeto terceirizou essas atividades, repartindo assim o lucro final com seus parceiros que executaram a colheita, processamento e comercialização. Este modelo ainda oferece a vantagem de, num primeiro momento, trabalhar com profissionais mais experientes,

principalmente nas etapas de comercialização, onde costumeiramente os próprios técnicos florestais são os encarregados de vender a madeira.

O manejo florestal comunitário e em pequena escala são alternativas a este sistema de exploração humana e também florestal. Ao aumentar a renda das famílias, através da agregação de valor ao produto florestal, diminui a necessidade de exploração intensiva da floresta. Com uma menor área explorada a família consegue uma maior renda.

\subsubsection{Meios de transporte}

A maioria das comunidades $(60,7 \%)$ possui acesso através de rio (Figura 25). As comunidades de várzea caracterizadas encontram-se em rios, igarapés e furos próximos ao rio Amazonas e Jarí. Algumas em terra firme possuem acesso por rios tributários ou subtributários do rio Amazonas. 
Outra grande parte das comunidades (43\%) possui acesso por estrada de piçarra e minorias por estrada de terra $(7,1 \%)$ e ferroviária $(5,4 \%)$. O Amapá possui uma estrada de ferro, construída pelo grupo CAEMI para escoamento do minério de manganês, estendendo-se da sede municipal de Serra do Navio à sede de Santana, situada na região metropolitana de Macapá.

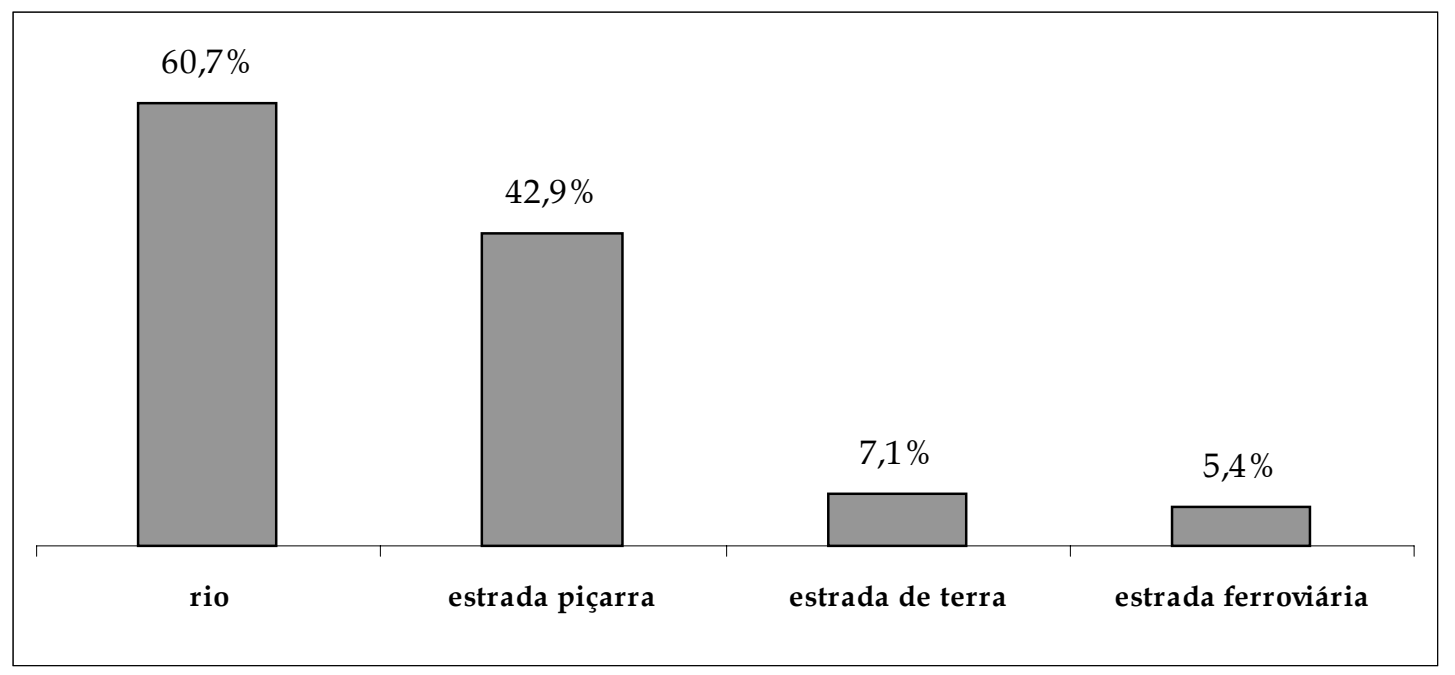

Figura 25 - Meios de acesso às comunidades.

$\mathrm{O}$ acesso às comunidades geralmente é feito durante todo o ano (83\%). Algumas comunidades (17\%) onde o acesso se dá por estrada de terra só possuem esta via durante os meses de verão amazônico.

As comunidades ribeirinhas próximas ao rios Amazonas e Jarí podem ter o acesso influenciado pelas estações do ano, sendo o inverno o melhor período do ano para o tráfego de grandes embarcações e também o transporte de madeira, e pela ocorrência de marés.

$\mathrm{Na}$ região do Bailique, os efeitos das marés sobre a acessibilidade das comunidades se tornam bem mais importantes do que das estações do ano. De maneira geral, apenas as comunidades sediadas às margens de rios menores podem enfrentar problemas graves de acesso durante o verão. 
Os veículos mais utilizados são barcos, em 57\% dos casos, canoas, 52\%, e caminhões em $41 \%$ das comunidades. Para a maior parte das comunidades às margens de rios maiores, é possível a utilização de barcos de até 15 t durante todo o ano.

A locomoção nas áreas próximas a sede das comunidades normalmente é feita através de canoas a remo, mais de 93\% das comunidades de várzea possuem. Esse é o veículo mais utilizado para chegarem as áreas de roçado e também as áreas utilizados para o extrativismo.

Os caminhões são normalmente utilizados para o escoamento da produção dos comunitários até feiras ou outros pontos de venda, e geralmente pertencem ao governo (estadual e municipal) ou às organizações sociais internas da comunidade (associações e cooperativas). Na listagem das comunidades do Amapá que participam da feira do produtor utilizando o transporte da SEAF, estão 21 das 56 comunidades amostradas no levantamento. Famílias entrevistadas de uma destas 21 comunidades, queixaram-se de que o transporte ultimamente não está sendo fornecido.

Outros veículos citados são carros e camionetas (3,5\% das comunidades), trem (em três comunidades) e tratores $(3,5 \%)$. Apenas uma comunidade é servida por serviço público de ônibus (Assentamento Vila do Maracá/Mazagão).

Cerca de $30 \%$ das comunidades possuem apenas uma opção de transporte (sendo $25 \%$ através de caminhão). Cerca de $59 \%$ das comunidades possuem 2 opções de transporte (sendo $48 \%$ constituído por barcos e canoas) e 5,3\% das comunidades possuem três opções de transporte (Tabela 10).

Aproximadamente $32 \%$ dos entrevistados declararam que a freqüência do transporte é variada dependendo do aluguel de barcos ou veículos terrestres de alguém da comunidade principalmente, e 30\% semanal. Cerca de $9 \%$ das comunidades estão servidas de transporte com regularidade de 2 a 3 vezes por semana. Onze porcento o obtém diariamente. Quinzenalmente e mensalmente foram citados em 11\% e 7\% das comunidades, respectivamente. Normalmente o transporte de produtos com caminhões das prefeituras locais ou pela Secretaria Estadual ocorrem também quinzenalmente (Figura 26). 
Tabela 10. veículos de transporte utilizados pelas comunidades.

\begin{tabular}{|c|c|c|c|c|c|c|c|c|}
\hline \multirow{2}{*}{$\begin{array}{c}\text { Veículo } \\
\text { de transporte }\end{array}$} & \multicolumn{7}{|c|}{ Meios de Transporte utilizados pelas Comunidades } & \multirow[t]{2}{*}{ TOTAL } \\
\hline & Barco & Canoas & Caminhão & Trem & Carro & Trator & Ônibus & \\
\hline Nenhum & - & - & - & - & - & - & - & $5,3 \%(3)$ \\
\hline Subtotal 1 & & & & & & & & $5,3 \%(3)$ \\
\hline Um veículo & - & - & $\mathrm{X}$ & - & - & - & - & $25 \%(14)$ \\
\hline Um veículo & $\mathrm{X}$ & - & - & - & - & - & - & $3,5 \%(2)$ \\
\hline Um veículo & - & $X$ & - & - & - & - & - & $1,8 \%(1)$ \\
\hline Subtotal 2 & & & & & & & & $30,3 \%(17)$ \\
\hline Dois veículos & $X$ & $x$ & - & - & - & - & - & $48,2 \%(27)$ \\
\hline Dois veículos & $x$ & - & $x$ & - & - & - & - & $3,5 \%(2)$ \\
\hline Dois veículos & - & - & $x$ & $\mathrm{X}$ & - & - & - & $5,4 \%(3)$ \\
\hline Dois veículos & - & - & $X$ & - & - & $X$ & - & $1,8 \%(1)$ \\
\hline Subtotal 3 & & & & & & & & $58,9 \%(33)$ \\
\hline Três veículos & $x$ & - & $x$ & - & - & - & $x$ & $1,8 \%(1)$ \\
\hline Três veículos & - & $X$ & $X$ & - & $X$ & - & - & $1,8 \%(1)$ \\
\hline Três veículos & - & - & $x$ & - & $x$ & $x$ & - & $1,8 \%(1)$ \\
\hline Subtotal 4 & & & & & & & & $5,3 \%(3)$ \\
\hline TOTAL & & & & & & & & $100,0 \%$ \\
\hline Comunidades & $57,1 \%(32)$ & $51,7 \%(29)$ & $41 \%(23)$ & $5,3 \%(3)$ & $3,5 \%(2)$ & $3,5 \%(2)$ & $1,8 \%(1)$ & \\
\hline
\end{tabular}

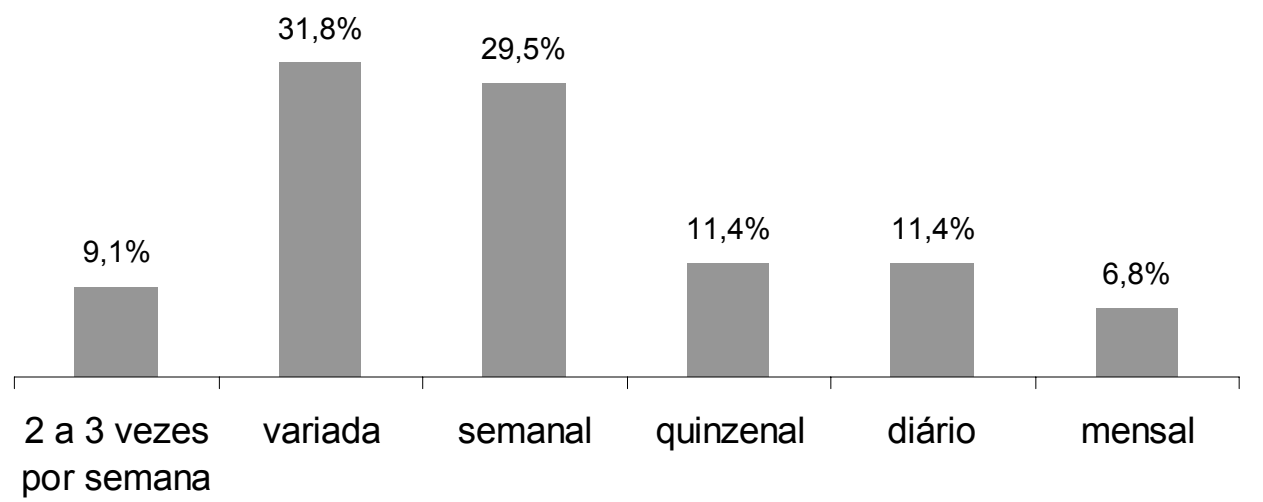

Figura 26 - Regularidade dos transportes. 
Sendo que o acesso as comunidades se dá principalmente por meio hidroviário, $83 \%$, e com possibilidade de movimentação durante todo o ano, o transporte dos produtos não representa impedimento técnico para a execução do manejo florestal. $\mathrm{O}$ governo poderia criar e manter um "serviço público de escoamento de produtos comunitários", onde os meios de transporte que poderiam ser utilizados são os barcos.

Este sistema de transporte e escoamento de cargas poderia colaborar com a organização de uma conformação produtiva comunal, onde cada comunidade seria responsável por uma etapa do sistema produtivo, sendo seus produtos, acabados até o etapa sob sua responsabilidade, e transportados até a comunidade responsável pela próxima etapa de acabamento através do "serviço público de escoamento de produtos comunitários".

\subsubsection{Infraestrutura comunitária}

\subsubsection{Escolas.}

Apenas $14 \%$ das comunidades não possuem escola. $\mathrm{Na}$ maior parte das comunidades (58\%) o ensino é oferecido até a 4a série. Em 14\%, até a 8a série. Em 6\% das comunidades são oferecidos menos anos de educação, $2 \%$ até a 2 a série e $4 \%$ apenas alfabetização. Finalmente, 4\% possuem educação até a 7 a série e $4 \%$ até a 5 a série (Figura 27).

$\mathrm{Na}$ maioria das vezes, os alunos apenas freqüentam a escola até a série oferecida dentro da comunidade. Em alguns casos, a família pode encaminhá-los até Mazagão ou Santana para continuar os estudos. Poucas vezes existem alternativas locais de prosseguimento dos estudos.

No arquipélago do Bailique, por exemplo, existe a Escola-Bosque, mas muitas

famílias não possuem meios de transporte adequados para encaminhar os estudantes até a escola pois a ocorrência diária de marés dificulta inclusive a viabilidade de transportes escolares oficiais contemplando várias comunidades à Escola-Bosque. 
Em muitas comunidades, foram encontrados problemas referentes à fixação dos professores às escolas. Muitas vezes, um professor permanece nestes locais por períodos relativamente breves, no máximo 1 ano, sendo posteriormente substituído. Também é comum, em escolas estaduais, professores que vão para Macapá receber o salário e passam alguns dias por mês fora da comunidade, prejudicando os estudantes.

Na região da terra firme alguns professores reclamaram de evasão escolar, uma vez que os alunos são obrigados a ajudar os pais na agricultura, e falta de interesse, justificando que alguns alunos apenas vão para a escola devido à merenda.

A média de alunos encontrada para as escolas de terra firme é igual a 88,8 . Nas regiões de várzea, incluindo agora o Bailique, a média de alunos é de 53,4. Na terra firme há em média 4 professores por escola e na várzea 2,3. As escolas da terra firme, além de melhor estruturadas com maior número de salas de aula, merendeiras e outros melhoramentos, estão em melhor estado de conservação do que as encontradas na várzea. Em 5 comunidades de várzea as escolas são casas doadas por moradores e 1 alugada pelo governo.

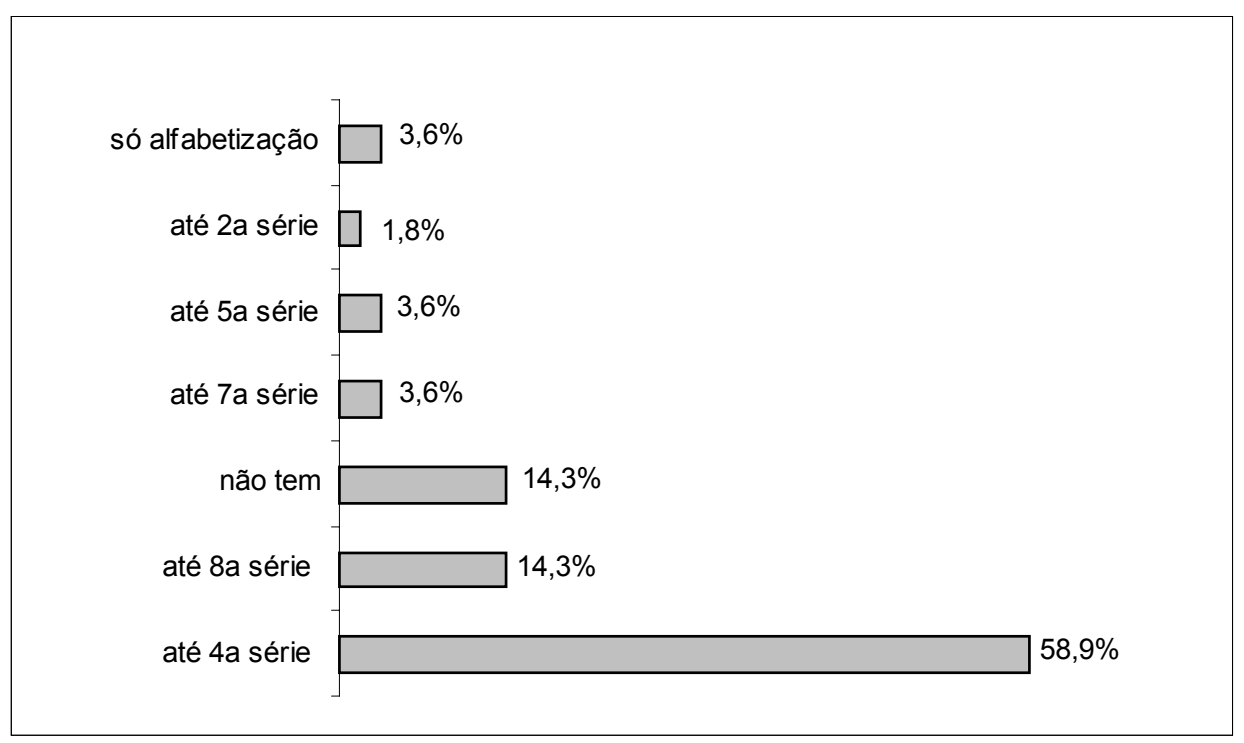

Figura 27 - Educação oferecida nas comunidades visitadas. 


\subsubsection{Postos Médicos}

Apenas $32 \%$ das comunidades possuem posto médico em funcionamento dentro de seus limites ou em local de fácil acesso. Em alguns destes casos, isso equivale a dizer que há pelo menos uma enfermeiro na comunidade que atende em sua própria casa.

Em todas estas comunidades há falta de medicamentos, e estes enfermeiros na maior parte das vezes podem apenas fazer pequenos curativos e dar algumas orientações. Raramente são capazes de fazer suturas, aplicar injeções; tirar lâminas para o diagnóstico de malária, encaminhar o material e trazer medicamentos.

Os principais problemas de saúde encontrados nas comunidades referem-se à malária, que no caso do arquipélago do Bailique muito rara; leshimaniose, sendo mais comum na região da terra firme; pneumonia, diarréia infantil e verminoses já que não há água tratada na maioria das comunidades visitadas, mas alguns entrevistados citaram que agentes de saúde entregam hipoclorito de sódio e orientam na utilização e tratamento da água, e gripes. Há visitas de agentes de saúde da SUCAM e FUNASA em algumas comunidades, voltadas principalmente ao tratamento de malária e leshimaniose. Há também agentes comunitários de saúde, que realizam trabalhos de orientação.

O curioso foi que não encontramos nas comunidades visitadas as famosas parteiras que participam do programa do governo estadual "Parteiras do Amapá".

Muitas comunidades utilizam plantas medicinais no tratamento de alguns problemas de saúde. É conhecida, por exemplo, a ação de uma planta chamada vulgarmente de "quina" no tratamento da malária. Cerca de $9 \%$ dos entrevistados declararam que suas comunidades receberam um curso de plantas medicinais promovido pelo IEPA. De qualquer forma, tratamentos mais sérios de saúde exigem que o morador se dirija a uma cidade próxima.

$\mathrm{Na}$ comunidade de Jarílândia, em Vitória do Jarí, foi citada a atuação da Associação das Parteiras Regionais do Amapá, porém a assistência dada por esta entidade a outras comunidades é desconhecida. Na comunidade Aterro do Muriacá, no mesmo município, durante os trabalhos de campo foi observada a presença de ambulância assistindo os comunitários. Na Vila Betel, municipio de Mazagão, um 
entrevistado declarou que existe anualmente a visita de uma equipe médica. Na região do Bailique, entrevistados disseram que há vacinação infantil e para idosos semestralmente promovida pela prefeitura, mas não souberam dizer para que doença eram as vacinas.

\subsubsection{Igrejas}

Em $81 \%$ das comunidades existem igrejas. As religiões encontradas foram a Católica (61\% das comunidades), Assembléia de Deus (28,6\%), Evangélica (7,1\%) e Adventista (5,4\%). Cerca de $46 \%$ das comunidades possuem apenas uma igreja (Católica, Assembléia de Deus e Evangélica com 36\%, 7\% e 4\%; respectivamente), 19,4\% duas igrejas (Católica/Assembléia ou Católica/Evangélica) e apenas 5\% das comunidades possuem três igrejas (Católica, Assembléia e Adventista) (Tabela 11).

Tabela 11. Igrejas, número e crença, existentes nas comunidades.

\begin{tabular}{|c|c|c|c|c|c|}
\hline \multirow[t]{2}{*}{ Quantidade de Igrejas } & \multicolumn{4}{|c|}{ Igrejas } & \multirow[t]{2}{*}{$\%$ das Comunidades } \\
\hline & Católica & Assembléia de Deus & Evangélica & Adventista & \\
\hline Nenhuma & - & - & - & - & $29 \%(16)$ \\
\hline Subtotal 1 & & & & & $28,6 \%(16)$ \\
\hline Uma igreja & $x$ & - & - & - & $35,7 \%(20)$ \\
\hline Uma igreja & - & $x$ & - & - & $7,1 \%(4)$ \\
\hline Uma igreja & - & - & $x$ & - & $3,6 \%(2)$ \\
\hline Subtotal 2 & & & & & $46,4 \%(26)$ \\
\hline Duas igrejas & $x$ & $x$ & - & - & $16,1 \%(9)$ \\
\hline Duas igrejas & $x$ & - & $x$ & - & $3,6 \%(2)$ \\
\hline Subtotal 3 & & & & & $19,6 \%(11)$ \\
\hline Três igrejas & $x$ & $x$ & - & $x$ & $5,4 \%(3)$ \\
\hline Subtotal 4 & & & & & $5,4 \%(3)$ \\
\hline TOTAL & & & & & $100,0 \%(56)$ \\
\hline$\%$ das Comunidades & $60,7 \%(34)$ & $28,6 \%(16)$ & $7,1 \%(4)$ & $5,4 \%(3)$ & \\
\hline
\end{tabular}




\subsubsection{Sedes Sociais}

Aproximadamente $56 \%$ das comunidades possuem alguma sede social (sede de associação ou cooperativa, centros comunitários ou barracão de igrejas). Nas comunidades em que não há sedes sociais, as reuniões comunitárias e outros encontros ocorrem nas escolas ou casas particulares.

\subsubsection{Comércios}

Cerca de 70\% das comunidades não possuem nenhum tipo de comércio. Vinte porcento possuem poucos (alguns gêneros alimentícios, principalmente), 4\% possuem alguns comércios (gêneros alimentícios e/ou mercearias, basicamente) e 7\% possuem vários estabelecimentos (mercearias, farmácias, prestação de serviços, etc.) Neste último grupo geralmente estão comunidades próximas de cidades, vilas ou áreas de garimpo.

\subsubsection{Energia Elétrica}

Mais de 54\% das comunidades possuem, ao menos com certa freqüência, energia elétrica. As fontes são a termoelétrica (5\%), hidroelétrica (14\%) e por grupos geradores (34\%) (Figura 28). A maioria das comunidades que possuem grupos geradores tem energia em suas casas no período noturno, normalmente apenas as casas locadas próximas à "vila" da comunidade onde estão as sedes sociais e escolas possuem energia elétrica.

Estes grupos geradores foram doados pela prefeitura ou pela CEA, adquiridos pela associação local ou comprados por uma família de moradores, sendo que neste caso apenas esta família possui energia elétrica em toda a comunidade. Os comunitários encontram dificuldades na obtenção e transporte de combustível, o pagamento da cota familiar de óleo diesel e na manutenção do equipamento, que na maioria das vezes é realizada por eles.

O fornecimento de energia do Amapá é provido principalmente por duas fontes: (i) uma estação hidroelétrica próxima de Ferreira Gomes, com capacidade de geração de 
$70 \mathrm{MW}$ e (ii) uma termoelétrica à diesel em Santana, gerando $111 \mathrm{MW}$. Estas duas fontes são administradas pela companhia federal ELETRONORTE.

A companhia estadual, CEA, está encarregada da distribuição de energia e de atender comunidades que não estão ligadas às redes elétricas. Para isso, operam vários grupos-geradores diesel para suprir alguns locais mais populosos. A capacidade de geração total do CEA é $8 \mathrm{MW}$. As redes elétricas estão sendo estendidas ao longo da rodovia BR 156 para o norte do Estado, mas a maioria das comunidades rurais vão permanecer sem qualquer fonte de suprimento de energia.

A CEA recebe fortes subsídios. Seu custo médio por MWh é de cerca de R\$ 380,00 enquanto que arrecada apenas R \$ 105,00. Custos de eletrificação por Km de uma nova linha de transmissão de energia estão acima de $\mathrm{R} \$$ 70.000. Por estas razões, provavelmente a CEA será privatizada em breve. Como a distribuição de energia nas proximidades da populosa Macapá é provável de ser implantada, há uma probabilidade de grande parte dos grupos geradores existentes serem tirados de operação. Embora muitas comunidades rurais no Amapá possuam pequenos grupos geradores, sua operação é restrita às limitações do equipamento e ao custo alto do combustível. Existe hoje uma necessidade real de geração energética descentralizada para o Amapá.

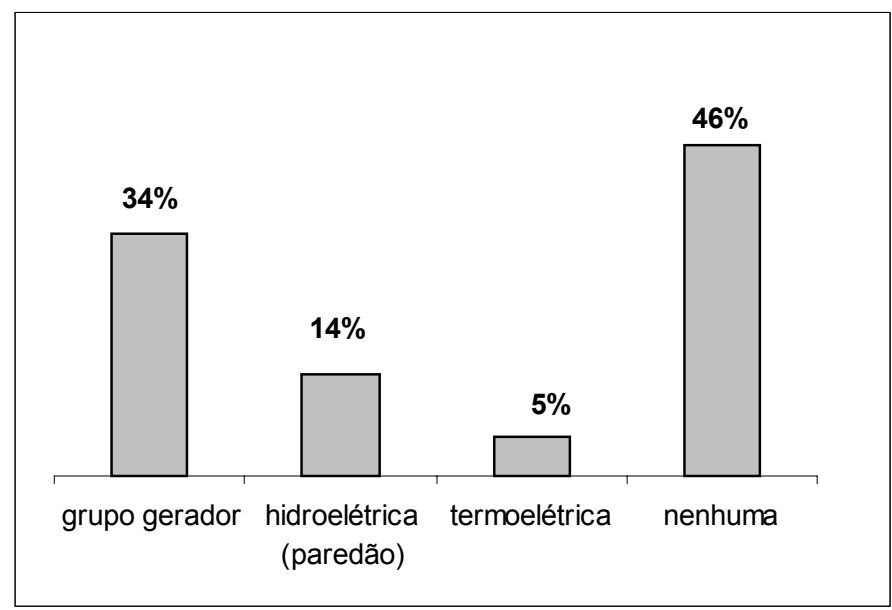

Figura 28 - Fontes de energia elétrica nas comunidades visitadas. 


\subsubsection{Assistência técnica}

Cerca de $48 \%$ das comunidades visitadas recebem algum tipo de assistência técnica agrícola vinda do RURAP. Um pouco menos de 10\% também disseram ter recebido algum auxílio do INCRA, em um caso auxílio financeiro para solução de problemas técnicos, dado pelo LUMIAR. Vinte e cinco porcento das comunidades, as locadas na Reserva Extrativista do Rio CaJarí, recebem alguma assistência do CNPT/IBAMA.

Para o Assentamento do Munguba, no município de Porto Grande, havia sido contratada uma empresa particular de assistência técnica há alguns anos e, no Assentamento Nova Colina, também no mesmo município, as associações decidirão entre duas empresas particulares e o RURAP para a extensão rural.

O Projeto LUMIAR visava implantar um serviço descentralizado de assistência aos Projetos de Assentamento de Reforma Agrária do Governo Federal. Tinha como objetivo viabilizar os assentamentos, tornando-os unidades de produção estruturadas voltadas para o mercado e integradas à dinâmica do desenvolvimento municipal e regional (INCRA, 2000). Era formado por um grupo de técnicos terceirizado pelo Incra. Foi suspenso recentemente, diante de denúncias de que estaria cobrando "pedágios" para arrecadar recursos ao MST. A pouco tempo atrás, desenvolvia assistência técnica junto a $70 \%$ dos assentados dos projetos federais de reforma agrária (Agricultura, 2000).

Fora os cursos dados em manuseio de motosserra (ver 5.3.5) nenhuma comunidade visitada recebe assistência técnica na área florestal. Para a viabilização dos projetos de manejo florestal existe a necessidade de criar instrumentos, não como o segundo exemplo citado acima, onde, se a estrutura estatal não é suficiente para atender as demandas por assistência técnica florestal, é necessária a contratação de empresas ou organizações não governamentais para suprir a falta da extensão florestal.

Como encontrar os parceiros ideais para atender as comunidades? Essa discussão nos remete a falta de educação básica, que é reflexo da estrutura primária que a administração pública apresenta para tratar de uma importante ferramenta de 
desenvolvimento pessoal e conseqüentemente social, a educação. Com a sociedade ciente da sua cidadania, essas situações poderiam ser minimizadas.

O sistema de assistência técnica do RURAP, se mostrou eficiente de acordo com as possibilidades oferecidas pelas condições de trabalho que possuem pois, somente um técnico para cada município é muito pouco para atender com eficácia todas as comunidades. As comunidades que são mais assistidas pelos técnicos notadamente possuem mais condições de produção, seja agrícola ou mesmo florestal. Uma possibilidade de melhorar o sistema de assistência técnica seria através do aumento do corpo técnico e reciclagem dos técnicos já contratados em técnicas de manejo florestal, linhas de créditos existentes, funcionamento do sistema financeiro para agricultura e manejo florestal e assistência para a elaboração de projetos para a obtenção de financiamentos.

\subsubsection{Acesso a crédito}

Apenas $12 \%$ dos entrevistados disseram já ter recebido algum apoio a fundo perdido. Destes, 33\% o utilizaram investindo em culturas agrícolas, $8 \%$ em pecuária e fruticultura, $8 \%$ em pecuária e $8 \%$ na atividade extrativista (manejo de açaí). Não há informações sobre o uso do apoio em $42 \%$ dos casos (Tabela 12).

As fontes de crédito conhecidas pelos entrevistados são o FNO (35\%), PROCERA (22\%), PRODEX (15\%), FRAP, PRONAF e PRORURAL (13\% das cada) e Programas de Fomento da Reforma Agrária (2\%). 
Tabela 12. Comunidades que já receberam Apoio a Fundo Perdido, identificadas pelo número do questionário.

\begin{tabular}{|c|c|c|c|c|}
\hline Comunidade & Projeto & Época & Benefícios resultantes & Observações \\
\hline 1 & - & - & - & - \\
\hline 5 & Auxílio - INCRA & - & - & receberam $\mathrm{R} \$ 1.019$ \\
\hline 9 & Procera & - & - & - \\
\hline 18 & PED & - & despolpadora de frutos & - \\
\hline 21 & PED & - & não sabe & está sendo utilizado pela Prefeitura \\
\hline 22 & Procera & - & - & - \\
\hline 25 & Auxílio - INCRA & - & plantio de banana, mandioca & - \\
\hline 28 & PROCERA & - & custeio de produção & - \\
\hline 30 & FRAP & - & compra de implementos agrícolas & - \\
\hline 32 & - & - & custeio de mandioca & - \\
\hline 38 & FNO & 1992 & plantio de laranja e cupuaçu. Gado. & - \\
\hline 41 & $\begin{array}{c}\text { convênio governo, Seaf e } \\
\text { cooperativa }\end{array}$ & - & - & - \\
\hline 45 & FRAP-SEAF & Fev/99 & manejo de açaí & - \\
\hline
\end{tabular}

A porcentagem de entrevistados que já adquiriram algum tipo de financiamento é ainda menor: $14 \%$. A maioria (71\%) utilizou-o ao menos parcialmente na agricultura; seguido pela compra de motor para barco e pecuária (7\% cada - Tabela 13). É expressivo o percentual de entrevistados que, além de nunca ter recebido nada, não conhecem nenhuma fonte de financiamento $(30 \%)$. 
Tabela 13. Lista das comunidades que receberam financiamentos bancários, época e em que foi utilizado, identificadas pelo número do questionário.

\begin{tabular}{cccccc}
\hline ID & Qual & Local e Data & Em que foi utilizado & Banco & Quem apoiou \\
\hline 1 & PROCERA & 1992 & culturas permanentes & BASA, através do INCRA & Associação (ATEXMA) \\
10 & PROCERA & Macapá & Plantio de mandioca & BASA & Associação (AZAP) \\
17 & PROCERA & 1997 & plantio, adubação e alimentação & BASA & LUMIAR \\
22 & PROCERA & 1997 & plantio de mandioca e banana & BASA & - \\
23 & PROCERA & $?$ & jamais recebeu & BASA & RURAP \\
23 & PROCERA & $?$ & lavoura e construção de casa & BASA & - \\
24 & - & 1963 & limpeza de áreas para plantio & Banco do Brasil & RURAP \\
26 & FNO & Macapá (1984) & Agropecuária & Basa, Banco do Brasil & Governo \\
30 & FRAP & 1997 & BANAP & - \\
30 & FRAP & $?$ & máquina para fazer ração & BANAP & - \\
30 & - & $?$ & lavoura/gado & BANESPA & INCRA \\
32 & PROCERA & 1993 & plantio de fruteiras & BASA & RAssociação (AMAJA) \\
38 & - & Macapá - 95 e 96 & fruticultura & BASA via SEAF & motor para barco \\
45 & Colônia G-1 & Macapá & & &
\end{tabular}

Os financiamentos estão disponíveis apenas para as famílias com áreas regularizadas, detentores de título definitivo, ou proprietários em terras públicas com carta de anuência ${ }^{18}$. Observou-se isso na prática, onde as comunidades que não possuíam algum documento fundiário e nem assistência de algum órgão extencionista, nunca obtiveram financiamento. Porém, duas comunidades (assentamento do Silvestre, em Serra do Navio e comunidade São Lázaro, em Laranjal do Jarí) que não detêm documentos fundiários que caracterizam justa posse de terras (segundo a Instrução Normativa IBAMA 06/98) obtiveram o financiamento bancário (junto ao BASA e BANAP, respectivamente) através de outras instituições, como Projeto LUMIAR e Associação AMAJA.

A ausência dos técnicos para a preparação de projetos, a política de crédito agrícola brasileira (que financia apenas cerca de $15 \%$ da produção) e as altas taxas de

${ }^{18}$ José Benatti. Comunicação pessoal, 2000. 
juros cobradas (apenas o PRONAF oferece taxas abaixo de 6\%) são fatores que, atualmente, dificultam muito a aquisição de crédito pelos assentados e comunitários ${ }^{19}$.

No Estado do Amapá, o BASA cedeu, no período de 1989-99, financiamentos no meio rural da ordem de 45 milhões de reais. Estes recursos foram voltados principalmente à fruticultura, financiando produtores organizados em associações e cooperativas. Cerca de $67 \%$ destes financiamentos se destinaram a micro e pequenos beneficiários (BASA, 2000).

O Programa Nacional de Florestas -PNF-, lançado em setembro de 2000, possui um item dedicado as "populações tradicionais e indígenas", com o objetivo de "apoiar e promover a incorporação das populações tradicionais e indígenas ao processo produtivo, assegurando sua subsistência e sustentabilidade nas áreas com potencial para a produção florestal racional e múltipla...". Pretende atingir esse objetivo através da realização de estudos que possibilitem o uso sustentável das Reservas Extrativistas e Terras Indígenas. Ou seja, somente vai trabalhar com as populações que estiverem dentro de unidades de conservação de uso direto, sendo essas consideradas tradicionais ou não.

\subsubsection{Produção florestal}

\subsubsection{Espécies exploradas}

As principais espécies exploradas pelos comunitários de terra firme, para consumo ou venda, ou reconhecidas pelo valor madeireiro são o angelim vermelho (Dinizia excelsa) e rajado (Pithecelobium racemosum), maçaranduba (Manikara sp.), louro (Ocotea sp.), ipê (Tabebuia sp.), sucupira (Bowdichia sp.), freijó (Cordia sp.), jatobá (Hymenaea courbaril), piquiá (Caryocar villosum), jarana (Lecythis sp.), acapu (Vouacapoua americana), andiroba (Carapa guianensis), quaruba (Vochysia maxima) e paricá (Schizolobium sp.).

\footnotetext{
${ }^{19}$ Sebastião Rocha, diretor de política agrária da Confederação Nacional dos Trabalhadores na Agricultura, em depoimento ao Jornal "O Liberal", de 25/09/2000.
} 
Na várzea, pau-mulato (Calycophylum spruceanum), maçaranduba (Manilkara $s p$.), acapu (V. americana), macacaúba (Platymiscium sp.), andiroba (C.guianensis), jutaí (Hymenaeae sp.), pracuúba (Trichilia sp.), sapucaia (Lecythis sp.), virola (Virola surinamensis) e cedro (Cedrela sp.). Há uma preferência na região da várzea do Amapá pela pracuúba, pau-mulato e macaúba. No arquipélago do Bailique, andiroba, pracuúba e macacaúba.

\subsubsection{Destino da produção}

Todas as comunidades realizam a exploração florestal pelo menos para consumo, seja na construção de casas e outras benfeitorias e para cocção (fonte de enrgia).

Cerca de 54\% das comunidades utilizam a madeira (processada ou bruta), além do consumo interno, para obtenção de renda. Uma minoria delas vende a madeira em toras. Na comunidade do Matauaú, em Vitória do Jarí, por exemplo, foi claramente citada a presença ostensiva de compradores/atravessadores na região, os chamados "toreiros do Pará". Existe também a atuação de empresas compradoras de madeira como a Icomi, que foi citada na comunidade Água Fria, em Pedra Branca do Amapari, e na região da várzea, algumas serrarias locais compram madeira em toras, sendo essas de propriedade de comunitários, e presente em pelo menos 7 comunidades.

A venda de madeira processada é predominante. Na região da terra firme, como as serrarias são distantes, o desdobro das toras é feito com motosserra, e as peças são geralmente vendidas a outros comunitários. Alguns entrevistados disseram fazer estas peças sob encomenda.

$\mathrm{Na}$ região da várzea (aqui incluindo o arquipélago do Bailique), um procedimento muito comum é levar as toras até as serrarias locais e "serrar de meia", isto é, os proprietários da serraria e das toras dividem as peças produzidas. Em seguida, podem vendê-las localmente ou nas cidades próximas. A motosserra também é utilizada para o desdobro de madeira nestas regiões. 
O mercado local não foi avaliado, mas não deve ser ignorado. Um dos exemplos de sucesso do MFC é o do Rio Cautário/AC, que tem obtido excelentes resultados com as parcerias desenvolvidas com o mercado local. Os comunitários, nesta etapa do projeto, não estão interessados em "exportar" a madeira para outros mercados, mesmo com as possibilidades já abertas com algumas industrias do Sul e Sudeste do país.

\subsubsection{Volume de madeira processada}

Em 7 comunidades visitadas foi levantado o volume de madeira processada pelas microsserrarias locais. Considerando-se dimensões médias das peças produzidas no local, de 3 a 4 metros de comprimento, 0,17 a 0,2 $\mathrm{m}$ de largura e 0,02 a 0,03 $\mathrm{m}$ de espessura (Veríssimo et al., 1999), estimativas do volume processado por estas microsserrarias foram realizadas (Tabela 14). Um diagnóstico mais preciso da atividade madeireira das microsserrarias do Estado pode ser visto na referência acima, que foi o estudo que indicou a necessidade da realização deste trabalho.

De acordo com a utilização das maiores e menores dimensões citadas, obtivemos um volume médio processado anual de $104 \mathrm{~m}^{3}$ a $252 \mathrm{~m}^{3}$ por serraria, respectivamente. Considerando-se um rendimento médio do processamento de $28 \%$ (Veríssimo et al., 1999), têm-se que estas comunidades exploram em média entre 371 e $899 \mathrm{~m}^{3}$ de madeira anualmente (Tabela 14).

Todas as serrarias consideradas neste cálculo estão localizadas na região da várzea do Amapá, e exploram conjuntamente entre $2.600 \mathrm{~m}^{3}$ e $6.300 \mathrm{~m}^{3}$ anuais de madeira. Estes valores representam entre 1,9\% a 4,5\% do consumo total de madeira das microsserrarias existentes no Estado (140.000 $\mathrm{m}^{3}$ - vide Veríssimo et al., 1999). A grande amplitude de variação do consumo se deve a características do mercado. 
Tabela 14. Volume e consumo de madeira processada mensalmente para as serrarias das comunidades amostradas.

\begin{tabular}{|c|c|c|c|c|c|}
\hline \multirow[t]{2}{*}{ Comunidade } & \multirow[t]{2}{*}{ Madeira Processada (2000) } & \multicolumn{2}{|c|}{ Volume Anual Processado $\left(\mathrm{m}^{3}\right)$} & \multicolumn{2}{|c|}{$\begin{array}{l}\text { Consumo Anual } \\
\text { de Madeira }\left(\mathrm{m}^{3}\right)\end{array}$} \\
\hline & & Mínimo & Máximo & Mínimo & Máximo \\
\hline Comunidade do Espinhel & 100 dúzias de peças/mês & 146,88 & 345,6 & 524,6 & $1.234,3$ \\
\hline Comunidade Tambaqui & 100 dúzias de peças/mês & 146,88 & 345,6 & 524,6 & $1.234,3$ \\
\hline Comunidade Bispo & 45-50 dúzias de peças/mês & 66,096 & 172,8 & 236,1 & 617,1 \\
\hline Comunidade Açaituba & 50 dúzias de peças/mês & 73,44 & 172,8 & 262,3 & 617,1 \\
\hline Comunidade Irapi & 40-50 dúzias de peças/mês & 58,752 & 172,8 & 209,8 & 617,1 \\
\hline Comunidade Filadélfia & 60 dúzias de peças/mês & 88,128 & 207,36 & 314,7 & 740,6 \\
\hline Comunidade Retiro do & 100 dúzias de peças/mês & 146,88 & 345,6 & 524,6 & $1.234,3$ \\
\hline \multicolumn{6}{|l|}{ Ariramba } \\
\hline Comunidade Limão do Curuá & desconhecido & - & - & - & - \\
\hline Santa Ana & desconhecido & - & - & - & - \\
\hline Média & - & 103,9 & 251,8 & 370,9 & 899,3 \\
\hline Soma & - & 727,1 & $1.762,6$ & $2.596,6$ & $6.294,9$ \\
\hline
\end{tabular}

\subsubsection{Tipo de Exploração}

Nas comunidades de terra firme, o tipo de exploração florestal predominante é a "catraca" (58\%), onde as operações de corte, desgalhamento e toreamento são feitos com motosserra e posterior carregamento em caminhões (Figura 29). Cerca de 17\% utilizam o sistema manual (machado e estiva), 17\% utilizam como único equipamento a motosserra e apenas $8 \%$ a mecanizada (auxílio de tratores). Neste último caso, a exploração é conduzida por serrarias locais.

O sistema"catraca" é um conjunto de operações onde uma vez localizadas na floresta as árvores de valor econômico, são cortadas e toreadas com motosserra e arrastadas até pátios de estocagem com o auxílio de tratores agrícolas. Nos pátios, são embarcadas nos caminhões com auxílio de cabos de aço, utilizando o princípio da alavanca (Veríssimo et al., 1999). 


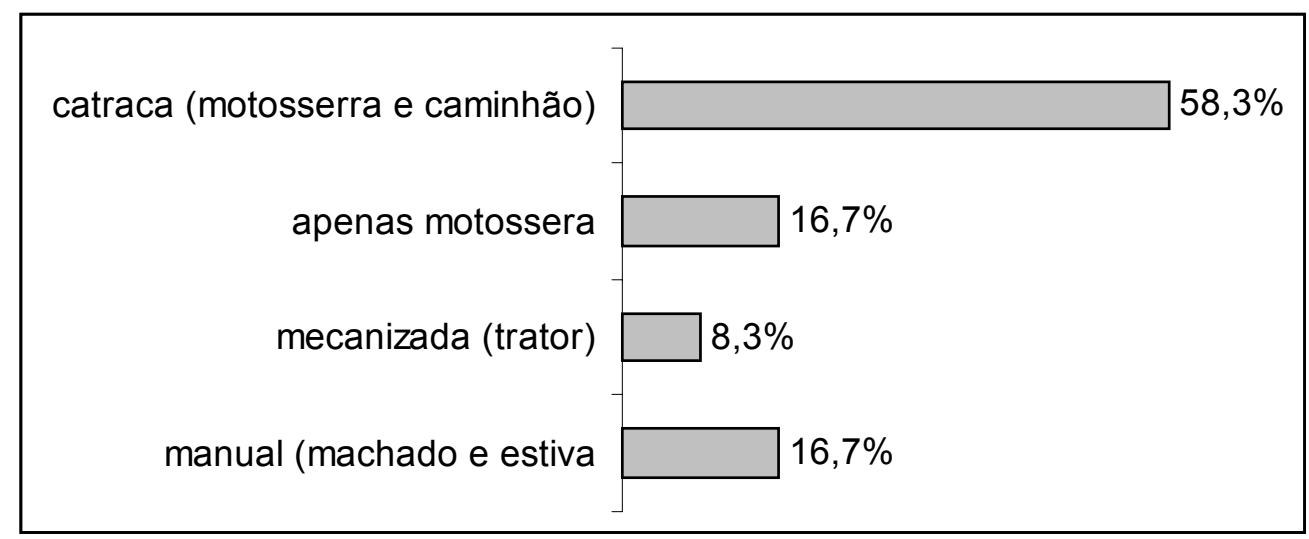

Figura 29 - Tipo de exploração florestal nas comunidades de terra firme.

Nas comunidades de várzea, a exploração predominante é a manual (machado e estiva, 69\%) já que o meio de transporte principal das toras é o fluvial, em jangadas. Vinte e cinco porcento das comunidades utilizam a motosserra, mas apenas $6 \%$ contam com o auxílio do caminhão no transporte de madeira (Figura 30). Uma das causas da preferência pelas espécies mais utilizadas (pracuúba, macacaúba e andiroba) é devido a sua grande durabilidade natural pois comumente passam-se meses (até um ano) entre o corte das árvores (a exploração é feita no verão) e o transporte das toras para o processamento (mais facilmente realizado no inverno), e essas espécies não se deterioram.

No sistema de exploração manual o corte é feito com machado e o arraste é feito manualmente. Os extratores procuram utilizar as enchentes para remover as toras de virola (madeira muito explorada nas áreas de várzea, leve e que tende a flutuar) do interior da floresta. Nos casos em que a área está afastada da influência das cheias, constroem-se trilhos de estivas de madeira através dos quais as toras são arrastadas manualmente. Finalmente, as toras são transportadas via jangadas até as serrarias (Veríssimo et al., 1999) (Figura 31).

Comparando-se as condições naturais de várzea e terra firme, o manejo florestal de várzea é aparentemente mais vantajoso do que o realizado em florestas de terra firme, em decorrência da maior simplicidade florística, crescimento mais rápido (devido à 
maior produtividade) e menor presença de cipós, o que reduz os danos durante a extração (Barros \& Uhl, 1996; citados por Arima et al., 1998).

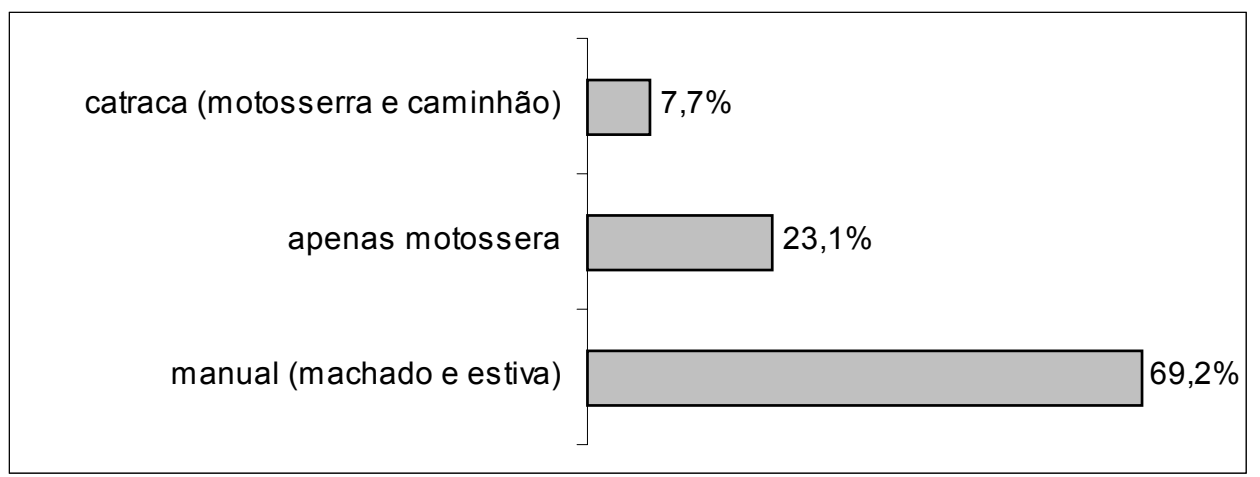

Figura 30 - Tipo de exploração florestal nas comunidades de várzea.

Em 96,4\% dos casos, a própria comunidade, organizada em núcleos familiares, faz a exploração. Entram nesta categoria também terceiros que recebem diárias pelo serviço. Em apenas 3,6\% dos casos quem realiza a exploração são serrarias locais (comunidade Água Branca, em Serra do Navio e comunidade São Lázaro, em Laranjal do Jarí).

As iniciativas de MFC pela Amazônia utilizam vários modelos de exploração, não existindo assim uma regra de quais são os melhores, mas sim quais os mais adequados para cada projeto, respeitando suas características particulares. Na tabela 15, abaixo, podemos observar os projetos e os tipos de exploração e processamento adotados.

$\mathrm{Na}$ maioria dos casos o modelo de exploração adotado é definido de acordo com os objetivos do projeto e a quantidade de recursos captados seu desenvolvimento. No caso do Amapá, a exploração seletiva manual e mecanizada, que prevê o uso de motosserras e transporte até a via principal de escoamento, rio, em época de cheia para facilitar o transporte primário com o auxilio de "bóias". 


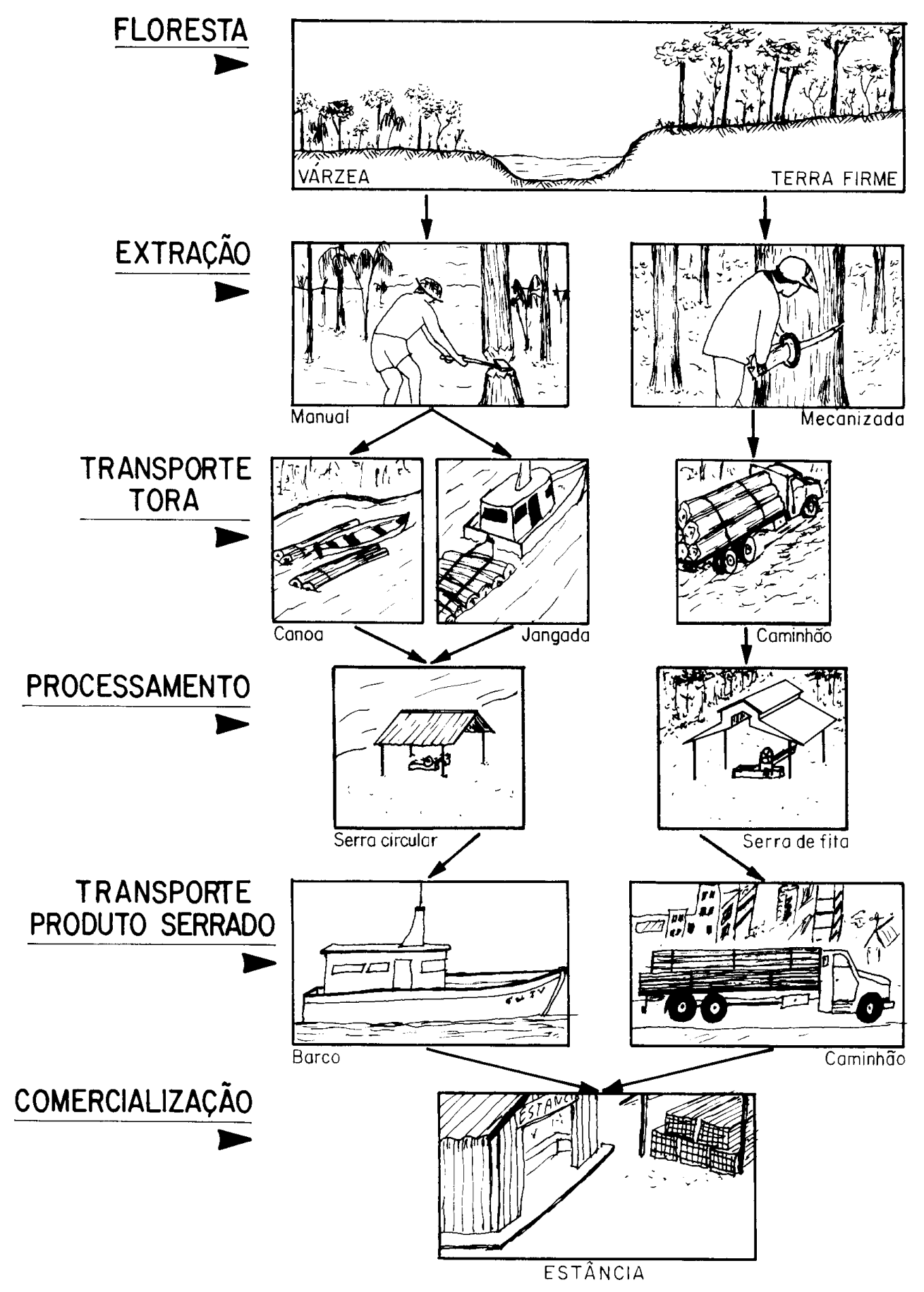

Figura 31 - Tipos de extração, forma de transporte de toras e madeira serrada e processamento de madeira no Estado do Amapá (Veríssimo et all, 1999). 
Tabela 15. Iniciativas de MFC e os tipos de exploração utilizado

\begin{tabular}{|c|c|c|c|c|}
\hline $\begin{array}{l}\text { Projeto } \\
\text { Entidade } \\
\text { (Comunidade) } \\
\end{array}$ & Local e ano de início & $\begin{array}{l}\text { Tipo de Floresta } \\
\text { Manejada }\end{array}$ & $\begin{array}{l}\text { Área de } \\
\text { Abrangência } \\
\text { do Projeto }\end{array}$ & $\begin{array}{l}\text { Modelo de Exploração } \\
\text { Aplicado }\end{array}$ \\
\hline $\begin{array}{l}\text { Mamirauá } \\
\text { Instituto Mamirauá } \\
\text { (Ribeirinhos) }\end{array}$ & $\begin{array}{l}\text { Tefé - AM } \\
1996\end{array}$ & $\begin{array}{l}\text { Florestas de Várzea do } \\
\text { Alto Solimões }\end{array}$ & 260.000 ha & $\begin{array}{l}\text { Exploração seletiva } \\
\text { manual }\end{array}$ \\
\hline $\begin{array}{l}\text { Rio Cautário } \\
\text { OSR - Ecoporé } \\
\text { (Extrativistas) }\end{array}$ & $\begin{array}{l}\text { Costa Marques } \\
\text { Vale do Anarí } \\
\text { Machadinho do Oeste } \\
\text { (todos em Rondônia) } 1995\end{array}$ & $\begin{array}{l}\text { Floresta de Terra } \\
\text { Firme }\end{array}$ & 964 ha/ano & $\begin{array}{l}\text { Exploração seletiva } \\
\text { mecanizada e manual }\end{array}$ \\
\hline $\begin{array}{l}\text { Porto de Moz } \\
\text { Laet } \\
\text { (Ribeirinhos) }\end{array}$ & $\begin{array}{l}\text { Porto de Móz - PA } \\
1997\end{array}$ & $\begin{array}{l}\text { Floresta de Terra } \\
\text { Firme na região do } \\
\text { Estuário }\end{array}$ & 13.700 ha & $\begin{array}{l}\text { Exploração seletiva } \\
\text { mecanizada e manual }\end{array}$ \\
\hline $\begin{array}{l}\text { Kayapós } \\
\text { Cl } \\
\text { (grupo indígena) }\end{array}$ & Redenção - PA & $\begin{array}{l}\text { Floresta de Terra } \\
\text { Firme }\end{array}$ & 250.000 ha & $\begin{array}{l}\text { Exploração seletiva } \\
\text { manual }\end{array}$ \\
\hline $\begin{array}{l}\text { Flona do Tapajós } \\
\text { Asmiprut, Aita, PSA, } \\
\text { STR Belterra } \\
\text { (Agricultores e } \\
\text { Ribeirinhos) }\end{array}$ & $\begin{array}{l}\text { Belterra - PA } \\
1996\end{array}$ & $\begin{array}{l}\text { Floresta de Terra } \\
\text { Firme }\end{array}$ & 76.683 ha & $\begin{array}{l}\text { Coleta sustentável de } \\
\text { óleo de andiroba e } \\
\text { copaíba }\end{array}$ \\
\hline $\begin{array}{l}\text { Marabá } \\
\text { Lasat } \\
\text { (Agricultores) }\end{array}$ & $\begin{array}{l}\text { Municípios ao longo da } \\
\text { Transamazônica } \\
1993\end{array}$ & $\begin{array}{l}\text { Floresta de Terra } \\
\text { Firme }\end{array}$ & $\begin{array}{l}340 \text { ha em três } \\
\text { municípios }\end{array}$ & $\begin{array}{l}\text { Exploração seletiva } \\
\text { mecanizada }\end{array}$ \\
\hline $\begin{array}{l}\text { Pedro Peixoto } \\
\text { Embrapa } \\
\text { (Agricultores) }\end{array}$ & $\begin{array}{l}\text { Pedro Peixoto - AC } \\
1995\end{array}$ & $\begin{array}{l}\text { Floresta de Terra } \\
\text { Firme }\end{array}$ & 440 ha & $\begin{array}{l}\text { Exploração seletiva } \\
\text { mecanizada }\end{array}$ \\
\hline $\begin{array}{l}\text { Porto Dias } \\
\text { CTA } \\
\text { (Extrativistas) }\end{array}$ & $\begin{array}{l}\text { Acrelândia - AC } \\
1995\end{array}$ & $\begin{array}{l}\text { Floresta de Terra } \\
\text { Firme }\end{array}$ & 3.000 ha & $\begin{array}{l}\text { Exploração seletiva } \\
\text { mecanizada }\end{array}$ \\
\hline $\begin{array}{l}\text { Gurupá } \\
\text { Fase } \\
\text { (Agricultores e } \\
\text { Extrativistas) }\end{array}$ & $\begin{array}{l}\text { Gurupá - PA } \\
1994\end{array}$ & $\begin{array}{l}\text { Floresta de Terra } \\
\text { Firme }\end{array}$ & 860.000 ha & $\begin{array}{l}\text { Exploração seletiva de } \\
\text { baixa intensidade }\end{array}$ \\
\hline $\begin{array}{l}\text { Arapiuns } \\
\text { Ipam } \\
\text { (Agricultores } \\
\text { Extrativistas) }\end{array}$ & $\begin{array}{l}\text { Santarém - PA } \\
1996\end{array}$ & $\begin{array}{l}\text { Floresta de Terra } \\
\text { Firme }\end{array}$ & Sem informação & $\begin{array}{l}\text { Exploração seletiva } \\
\text { mecanizada }\end{array}$ \\
\hline $\begin{array}{l}\text { Xikrin do Cateté } \\
\text { ISA } \\
\text { (grupo indígena) }\end{array}$ & $\begin{array}{l}\text { Parauapebas - PA } \\
1995\end{array}$ & $\begin{array}{l}\text { Floresta de Terra } \\
\text { Firme }\end{array}$ & 40.000 ha & $\begin{array}{l}\text { Exploração seletiva } \\
\text { mecanizada }\end{array}$ \\
\hline $\begin{array}{l}\text { Boa vista do Ramos } \\
\text { Imaflora } \\
\text { (Ribeirinhos) }\end{array}$ & $\begin{array}{l}\text { Boa Vista do Ramos - Rio } \\
\text { Curuçá - AM } \\
1998\end{array}$ & $\begin{array}{l}\text { Floresta de Terra } \\
\text { Firme }\end{array}$ & 5.000 ha & $\begin{array}{l}\text { Exploração seletiva } \\
\text { mecanizada }\end{array}$ \\
\hline $\begin{array}{l}\text { Uruará } \\
\text { Fundação Viver, } \\
\text { Produzir e Preservar } \\
\text { (Agricultores) }\end{array}$ & $\begin{array}{l}\text { Uruará - PA } \\
1999\end{array}$ & $\begin{array}{l}\text { Floresta de Terra } \\
\text { Firme }\end{array}$ & $12.000 \mathrm{ha}$ & $\begin{array}{l}\text { Exploração seletiva } \\
\text { mecanizada }\end{array}$ \\
\hline $\begin{array}{l}\text { F. E. Antimary } \\
\text { Funtac }\end{array}$ & $\begin{array}{l}\text { BuJarí - AC } \\
1998\end{array}$ & $\begin{array}{l}\text { Floresta de Terra } \\
\text { Firme }\end{array}$ & 1.070 ha & $\begin{array}{l}\text { Exploração seletiva } \\
\text { mecanizada }\end{array}$ \\
\hline
\end{tabular}

Fonte: Armelin, 2000. Relatório da II Oficina de MFC.

\subsubsection{O que entendem por manejo florestal}

Trinta e seis porcento dos entrevistados disseram que não entendem nada por manejo florestal, possivelmente inibidos pela entrevista. Quando discutiu-se sobre o treinamento dado a estas pessoas, mostrou-se que mesmo os treinamentos na área de silvicultura englobavam principalmente técnicas de manuseio de motosserra e viveiros, nada muito específico do manejo florestal. Imaginando uma relação com estes treinamentos em práticas de viveiros, $14 \%$ das respostas espontâneas diziam respeito a 
"replantar o mesmo número de árvores que foi derrubado na exploração" e 7\% a "reflorestar áreas desmatadas".

Outros 19\% optaram pela preservação/conservação de florestas e o nãodesmatamento como resposta. O IBAMA e o Batalhão (Polícia) Ambiental estão em freqüente contato com algumas destas comunidades, o que possivelmente acaba por difundir esses princípios. Cerca de 10\% imaginam apenas o corte das árvores mais velhas ou grossas e $5 \%$ o plantio de essências florestais em consórcio com plantas cultivadas e pastos para animais (SAFs). Aproximadamente $17 \%$ das respostas incluem o combate a incêndios, o desmatamento autorizado pela legislação, o desmatamento total de áreas florestais, etc. Finalmente, apenas $10 \%$ das respostas diziam respeito à utilização de técnicas de minimização dos impactos da exploração madeireira.

$\mathrm{O}$ treinamento para essas comunidades que vivem em contato tão próximo da floresta são os de práticas de manejo florestal. Esses treinamentos poderiam ser ministrados pela Fundação Floresta Tropical -FFT-, que atendendo a solicitação feita durante a II Oficina de Manejo Florestal Comunitário, realizada no município paraense de Marabá em setembro de 1999, já desenvolve um módulo de treinamento para iniciativas comunitárias e de pequena escala. $\mathrm{O}$ governo poderia estudar uma parceria com a FFT, e assim desenvolver um plano de treinamento para as comunidades amapaenses.

O conteúdo deste curso poderia ser basicamente:

- o plano de manejo florestal;

- inventário florestal;

- tratamentos pré-exploratórios;

- planejamento da exploração;

- técnicas de corte das árvores;

- arraste das toras;

- desdobro de toras no local de exploração;

- proteção contra incêndios florestais;

- tratamentos pós-exploratórios. 


\subsubsection{As expectativas em relação ao desenvolvimento}

Na opinião dos comunitários o desenvolvimento da comunidade, na maior parte das respostas, passa pelo aumento de sua capacidade produtiva. Desta forma, $48 \%$ dos entrevistados citou a agricultura, $33 \%$ a piscicultura, $26 \%$ extrativismo e pecuária e $2 \%$ implantação de viveiros de mudas como sendo as alternativas mais acreditadas (Figura 32). As atividades madeireiras só foram citadas depois de uma pergunta direta a respeito da atividade florestal madeireira, isso é um reflexo da dificuldade que encontram para os processos de licenciamento requeridos para a atividade florestal madeireira.

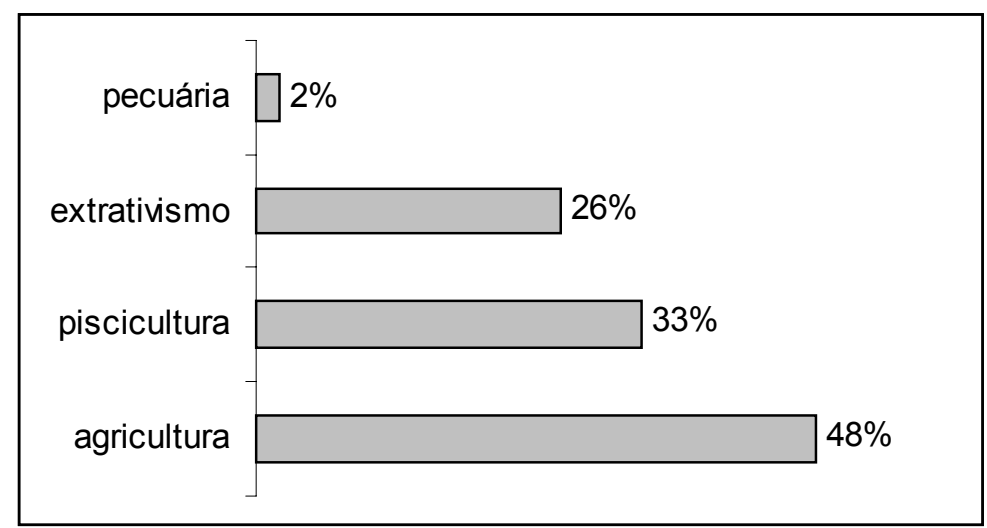

Figura 32 - Atividades citadas como alternativas de desenvolvimento para a comunidade.

Em segundo plano o desenvolvimento local está vinculado a agregação de valor à produção e melhores meios para a comercialização, sendo citados o escoamento de produção (17\%), beneficiamento (de frutos, farinha e outros, com $7 \%$ ), serraria $(10 \%)$, movelaria $(7 \%)$ e olaria $(2 \%)$.

Outras respostas dizem respeito à melhoria da estrutura da comunidade: infraestrutura (saúde, escolas, saneamento, comunicação, etc. - 24\%) e transporte por ferrovias $(2 \%)$, organização social comunitária/cooperativismo $(2 \%)$ e regularização fundiária (5\%). Dois porcento dos entrevistados não sabem e outros $2 \%$ citaram o manejo florestal. 
A expectativa geral em relação ao desenvolvimento gira em torno de fontes ou entidades externas que os auxiliem a alcançar estes objetivos. Cerca de 19\% apontaram a necessidade de assistência técnica, $10 \%$ de financiamento mas a grande maioria deles não sabe de que forma estes esforços e/ou auxílios poderiam ser obtidos para atender essas demandas.

O papel do Estado neste processo para alavancar o desenvolvimento das comunidades é de grande importância. Cabe a ele encontrar parceiros com capacidade suficiente para, junto com as comunidades, tentar encontrar caminhos para garantir a viabilidade econômica da produção comunitária. Num primeiro momento a maior necessidade é a organização social, ponto vital para o sucesso de qualquer iniciativa, seja ela florestal ou agrícola.

O Manejo Florestal, comunitário ou em pequena escala, poderá ser bem sucedido na Amazônia quando as famílias/comunidades tiverem:

a) acesso a informações a respeito do funcionamento do mercado (técnicas de comercialização, transformação, qualidade do produto, marketing, etc.);

b) as políticas públicas forem coerentes com a escala do empreendimento;

c) a competição com os produtos florestais ilegais for diminuída através da efetiva fiscalização por parte dos órgãos competentes;

d) os órgãos de extensão, agrícola e florestal, se preocupando também com a organização social das comunidades e não só com as culturas e seus produtos;

e) o MFC ou MFPE for encarado como mais uma alternativa para a viabilização econômica das comunidades e não a única, pois a renda familiar deve ser formada por um conjunto de atividades.

Para o governo do Estado enxergamos três cenários para o desenvolvimento e profissionalização das atividades florestais do Estado. São eles:

a) baixo investimento: promover cursos e eventos destinados ao aperfeiçoamento da organização social das comunidades. Essas 
comunidades poderiam depois desses treinamentos estarem fornecendo toras para outras comunidades transformarem;

b) médio investimento: seleção de algumas comunidades para receberem assistência técnica e financiamento de serrarias comunitárias. Essas comunidades comercializariam madeira serrada, fornecendo para empresas ou comunidade transformadoras;

c) alto investimento: seleção de algumas comunidades que receberiam investimentos para treinamento das famílias envolvidas nas operações florestais, comercialização, marketing e gerenciamento, financiamento das serrarias comunitárias e montagem de oficinas para agregar valor a madeira serrada através da produção de móveis e outros produtos de madeira. Essas comunidades colocariam no mercado produtos acabados com maior valor agregado a matéria prima.

Os cenários podem ser complementares ou três aplicados ao mesmo tempo, produzindo assim um sistema continuado de profissionalização da produção comunitária, onde depois de algumas etapas todas as comunidades poderiam estar aptas a integrar o cenário "Alto Investimento".

Em todos os cenários, deveriam ser desenvolvidas atividades de informação sobre a certificação florestal do Forest Stewardship Council - FSC-, que poderia facilitar a captação de recursos através de agências de colaboração multilaterais, a entrada dos produtos nos diversos mercados possíveis e principalmente garantir que as operações florestais seriam sempre as mais adequadas, social e ambientalmente, as condições das comunidades. 


\section{CONCLUSÕES}

Esse levantamento possui informações sócio-econômicas, e algumas ambientais, das comunidades caracterizadas que interessam a diversas esferas governamentais e também podem nortear a ação de novos estudos. Assim essas informações, juntamente com as áreas consideradas potenciais para o manejo florestal, devem ser colocadas em um SIG, para otimizar sua utilização pelo governo do Estado do Amapá.

O ponto de partida para o desenvolvimento da atividade florestal no estado será o desenvolvimento de políticas para a regularização fundiária. Pré-requisito para o licenciamento da atividade pelo IBAMA, que aceita todos os documentos de posse e uso da terra reconhecidos pelo INCRA.

Para o licenciamento do manejo florestal, 70,4\% das comunidades entrevistadas possuem algum tipo de documento aceito pelo IBAMA, porém a regularização fundiária é uma estratégia de desenvolvimento que visa também aumentar a perspectiva de continuidade, por longo prazo, das atividades desenvolvidas pelos usuários da terra.

Sendo que somente $25 \%$ das comunidades possuem a escritura da terra, o Governo do Estado deve se sensibilizar com o dado e promover um programa de regularização fundiária, revisando os processos e principalmente as taxas e impostos cobrados das áreas com situação fundiária regular, ponto diagnosticado como um dos impedimentos para a regularização fundiária.

Em 53,8\% das comunidades entrevistadas, localizadas nas áreas de várzea do Estado, e $20 \%$ das localizadas em terra firme possuem como principal atividade econômica a madeireira, e sendo que $60,7 \%$ delas possuem acesso por rios, mesmo 
algumas localizadas nas áreas de terra firme que possuem acesso também por rios tributários ou subtributários do rio Amazonas, uma das ações para o desenvolvimento do Estado é o desenvolvimento de sistemas hidroviários.

A infraestrutura para as hidrovias poderia ser desenvolvida em módulos, onde os primeiros módulos poderiam começar a operar para o transporte de passageiros, aumentando assim o intercâmbio de pessoas e experiências entre as comunidades e facilitando as ações de treinamento para as operações florestais.

O segundo módulo a ser desenvolvido poderia ser o de transporte de cargas, possibilitando o cenário de desenvolvimento que prevê a distribuição das atividades de manejo florestal, serraria e elaboração do produto final em comunidades diferentes, de acordo com suas aptidões naturais.

Em 48\% das comunidades visitadas a principal expectativa para o desenvolvimento regional são as atividades agrícolas. Numa primeira análise essa constatação parece estranha para uma região com recursos florestais abundantes, $25 \%$ das áreas florestais do Estado são indicadas para o manejo florestal de acordo com as condições econômicas do momento, e sendo que as atividades de manejo florestal não precisariam de gastos extremos de energia para a conversão das áreas florestais em sistemas agrícolas.

Mas analisando a situação pelo olhos dos comunitários, eles acabam tendo razão em sua escolha pela agricultura. Os processos de licenciamento florestal são extremamente complicados e até mesmo inacessíveis para as comunidades. Junta-se a isso o fato de nenhuma delas ter recebido qualquer tipo de assistência técnica para a realização do manejo florestal, a não ser o curso de segurança no manuseio de motosserras, recebido por $18 \%$ das comunidades.

Como no caso da agricultura, o manejo florestal também deve ter um órgão de assistência técnica especializada para o atendimento e suporte as atividades comunitárias. A criação dos grupos de produtores, como sugerido no FLORAP, e já em funcionamento no Estado do Acre é um modelo que pode atender algumas demandas geradas pela atividade florestal madeireira sem onerar demais o estado, pois a idéia é que esse grupo se torne independente e sustentável. 
No Estado do Pará outro modelo de grupo de produtores, este sem a participação do Estado, representa um bom exemplo que pode ser replicado no Amapá. O grupo é organizado e administrado pelas ONG's IMAZON, IMAFLORA e Amigos da Terra - Amazônia Brasileira, dando assistência técnica e jurídica para os produtores, e todo o sistema desenvolvido é custeado com recursos captados junto as empresas consumidoras da madeira.

O trabalho de organização e assistência aos produtores florestais é contínuo, e reforça a necessidade da criação de departamento de assistência técnica florestal dentro do RURAP, que é o órgão oficial de assistência técnica rural do Estado.

A necessidade de apoio as comunidades, para que possam superar os desafios, é também uma conclusão do Programa Nacional de Florestas, que destaca, como principais, entre esses desafios a regularização fundiária, tentando resolver os conflitos relacionados ao acesso aos recursos florestais, o fortalecimento da organização comunitária e geração de alternativas de renda.

Todas as comunidades caracterizadas estão aptas a desenvolverem atividades relacionadas ao manejo florestal, seja madeireiro ou não madeireiro. Possuem mão-deobra, ainda não capacitada, e estão localizadas dentro da área de viabilidade econômica para o manejo florestal (Tabela 16).

Os projetos pilotos devem ser desenvolvidos nas comunidades que já possuem atividade florestal e serraria na própria comunidade. Estas poderiam estar beneficiando as toras colhidas pelas outras comunidades (Tabela 17). 
Tabela 17. Comunidades que poderiam servir de projeto piloto para o processamento de madeira no âmbito do programa do governo.

\begin{tabular}{cc}
\hline Comunidade & Município \\
\hline Comunidade Retiro do Ariramba & Macapá \\
Comunidade do Espinhel & \\
Comunidade Tambaqui & \\
Comunidade Bispo & \\
Comunidade Açaituba & Mazagão \\
Comunidade Irapi & \\
Comunidade Filadélfia & \\
Comunidade Limão do Curuá & \\
Santa Ana & \\
\hline
\end{tabular}


Tabela 16. Municípios cujas florestas estão dentro da área de viabilidade econômica de exploração e suas comunidades potenciais para o desenvolvimento do manejo florestal comunitário.

\begin{tabular}{|c|c|c|c|c|c|c|c|c|}
\hline $\begin{array}{c}\text { Área de } \\
\text { viabilidade } \\
\text { econômica }\end{array}$ & Mazagão & Macapá & Serra do Navio & Porto Grande & Laranjal do Jarí & Pedra Branca & Ferreira Gomes & Vitória do Jarí \\
\hline & Açaituba & Buritizal & Água Branca & $\begin{array}{l}\text { Assentamento } \\
\text { Nova Colina }\end{array}$ & Água Branca & Água Fria & São Raimundo & $\begin{array}{l}\text { Aterro do } \\
\text { Muriacá }\end{array}$ \\
\hline & Bispo & Franquinho & Capivara & $\begin{array}{l}\text { Santa Maria do } \\
\text { Vila Nova }\end{array}$ & $\begin{array}{l}\text { Cachoeira de } \\
\text { S.Antonio do Jarí }\end{array}$ & Sete Ilhas & Triunfo & Jarílândia \\
\hline & Filadélfia & Igaçaba & Jararaca & $\begin{array}{l}\text { Assent. do } \\
\text { Munguba }\end{array}$ & Padaria & Tucano I & $\begin{array}{l}\text { Assent. Nova } \\
\text { Vida }\end{array}$ & Matauaú \\
\hline & Irapi & Jaburuzinho & $\begin{array}{l}\text { Perpetuo } \\
\text { Socorro }\end{array}$ & $\begin{array}{l}\text { Assent. Nova } \\
\text { Canãa }\end{array}$ & $\begin{array}{l}\text { São Francisco do } \\
\text { Iratapuru }\end{array}$ & Tucano II & & \\
\hline & Maranata & Limão do Curuá & $\begin{array}{l}\text { Assent. do } \\
\text { Silvestre }\end{array}$ & $\begin{array}{l}\text { São Sebastião do } \\
\text { Cachaco }\end{array}$ & Tira couro & & & \\
\hline & Menino Deus & $\begin{array}{l}\text { Livramento do } \\
\text { Bailique }\end{array}$ & $\begin{array}{l}\text { Ramal do } \\
\text { Cachaço }\end{array}$ & & & & & \\
\hline & Ramal do Pioneiro & $\begin{array}{l}\text { Marinheiro de } \\
\text { Fora }\end{array}$ & & & & & & \\
\hline & Retiro do Ariramba & & & & & & & \\
\hline & S.Antonio/Braço do Ajuruxi & & & & & & & \\
\hline \multirow[t]{14}{*}{ Comunidades } & Salvador Deus Proverá & & & & & & & \\
\hline & Santa Ana & & & & & & & \\
\hline & Santa Clara & & & & & & & \\
\hline & Santa Maria do Curuça & & & & & & & \\
\hline & Santo Antonio & & & & & & & \\
\hline & Santo Antonio do Camaipi & & & & & & & \\
\hline & Santo Antonio do Mutuacá & & & & & & & \\
\hline & São José do Maracá & & & & & & & \\
\hline & Sororoca & & & & & & & \\
\hline & Tambaqui & & & & & & & \\
\hline & Assent. Vila do Maracá & & & & & & & \\
\hline & Espinhel & & & & & & & \\
\hline & São Benedito do Rio Urubueno & & & & & & & \\
\hline & Vila Betel & & & & & & & \\
\hline
\end{tabular}


ANEXOS 


\section{A1 - Fotos}

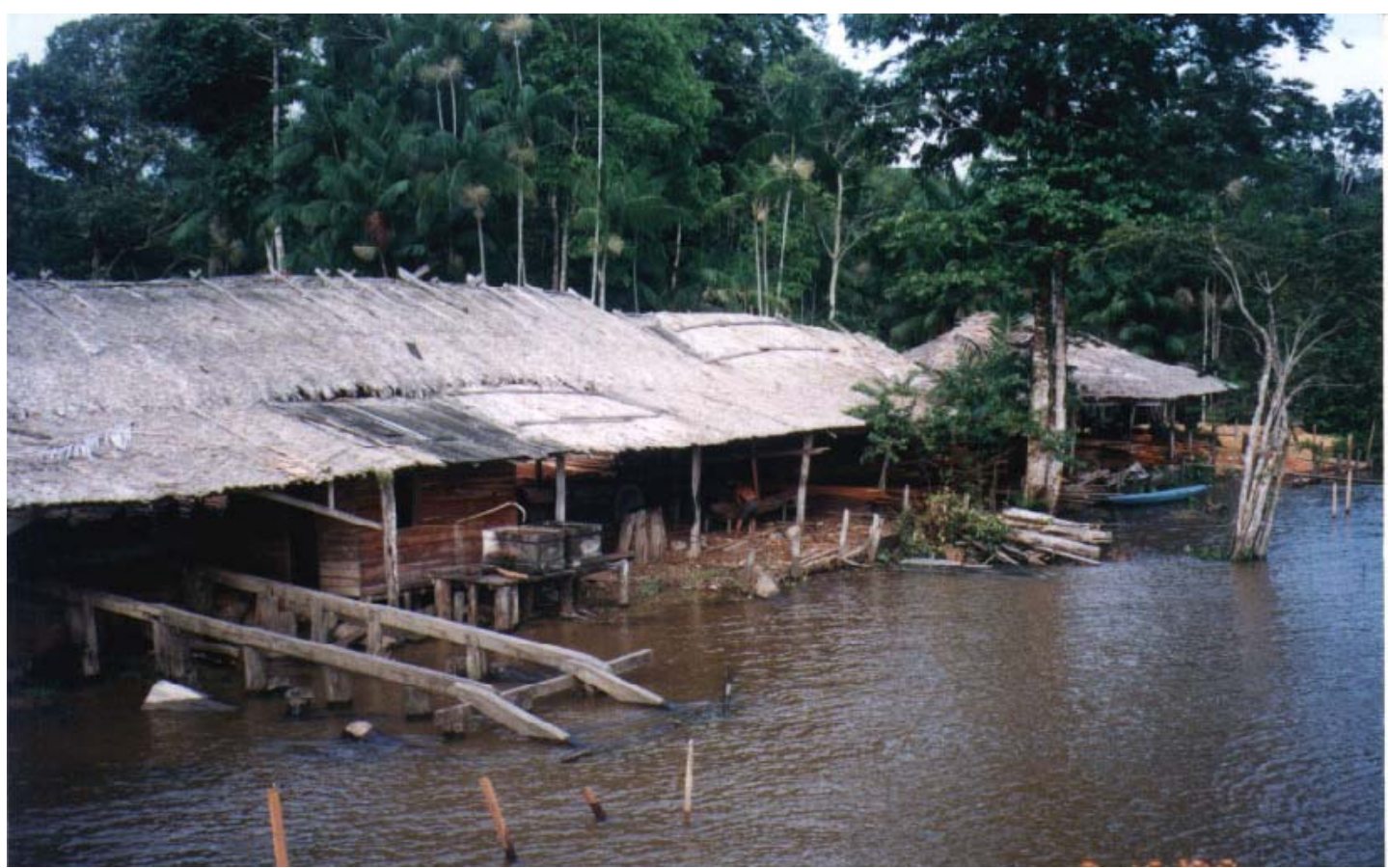

Figura 33 - Modelo de serraria comunitária do Estado do Amapá, município de Mazagão.

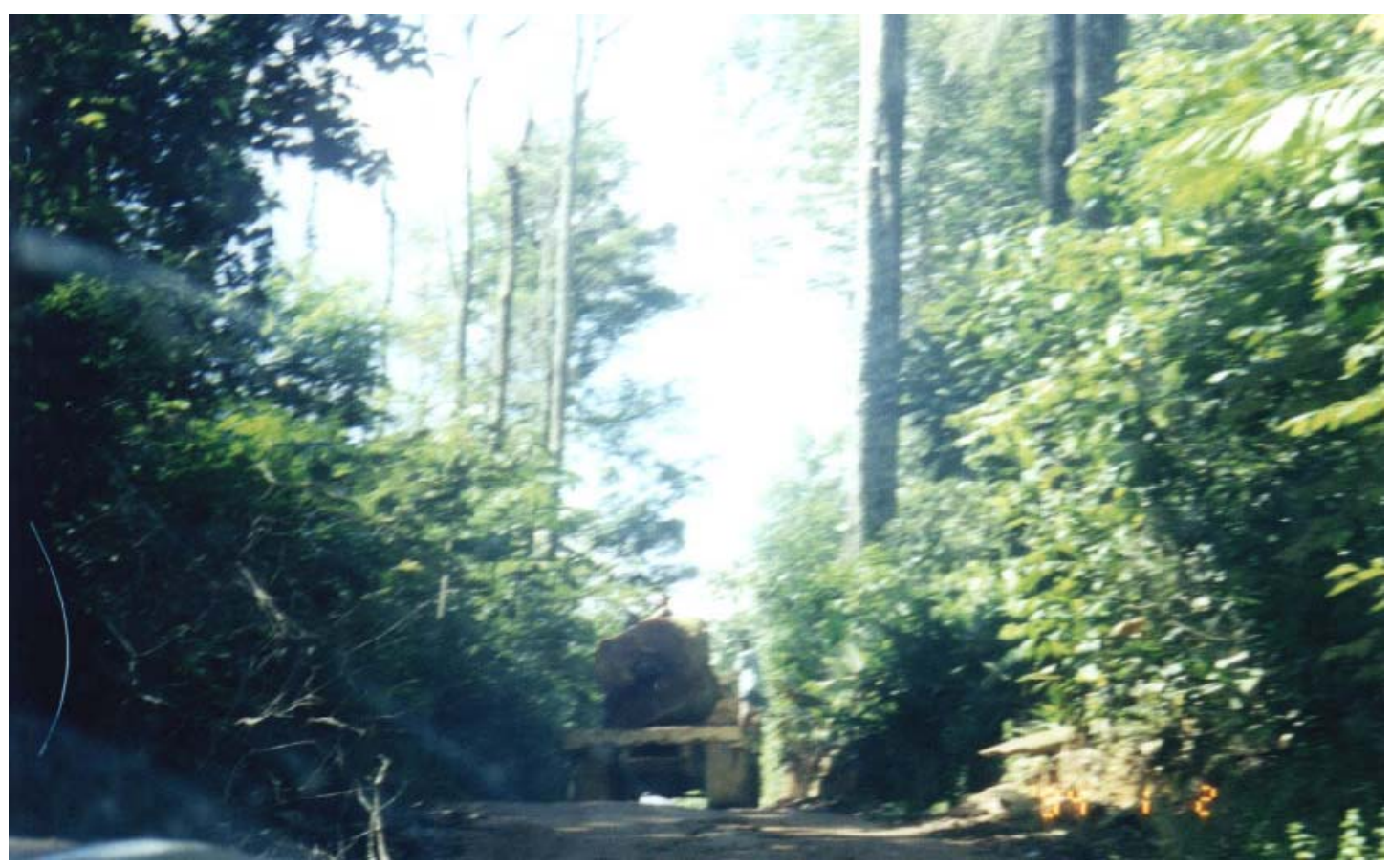

Figura 34 - Transporte de madeira com caminhão "toreiro", em floresta de terra firme. 


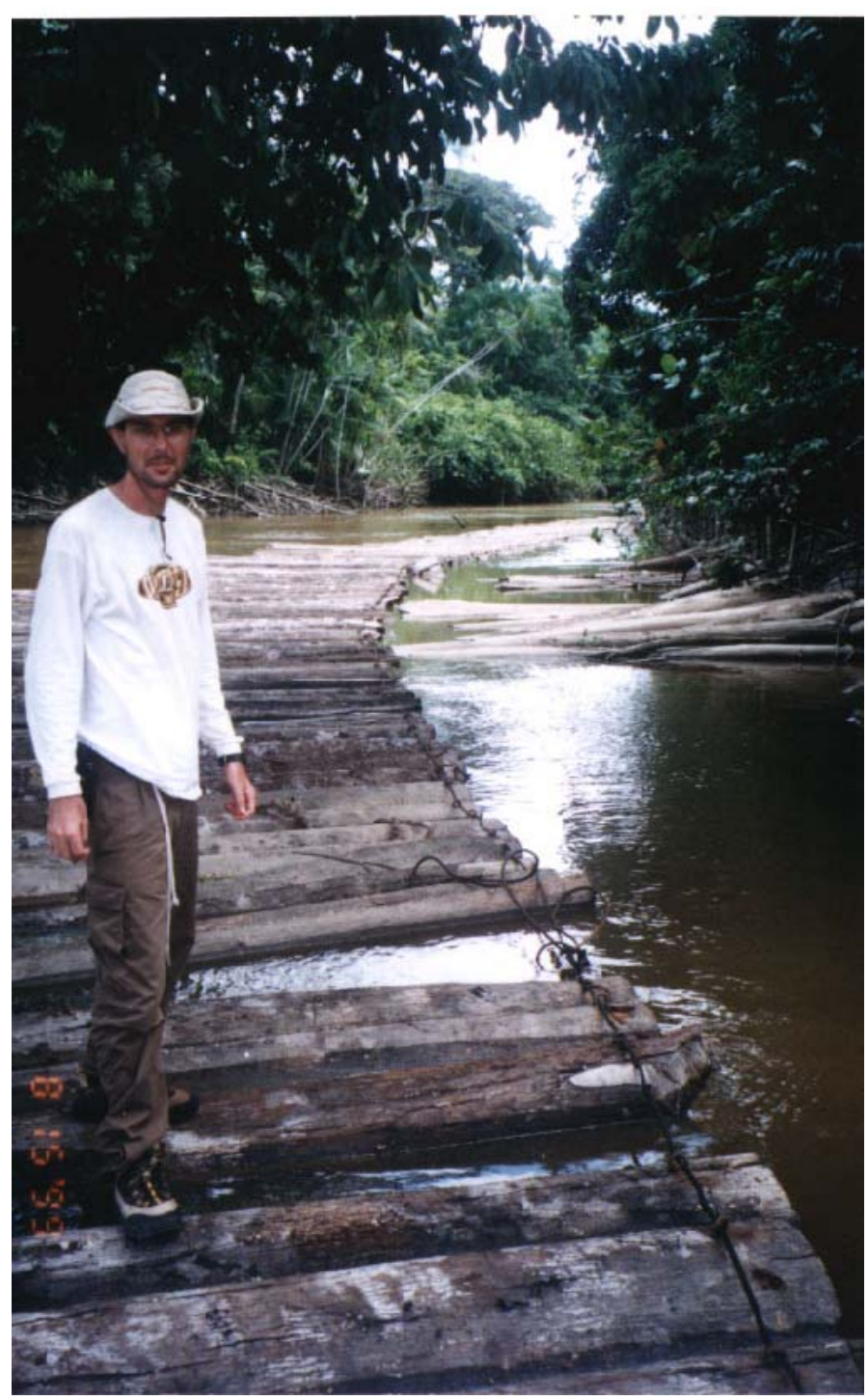

Figura 35 - Sistema de transporte de toras pelo rio, em florestas de várzea. 


\section{A2 - Instrução Normativa INCRA 41}

A Instrução Normativa INCRA 41, de maio de 2000, fixa as normas para a implementação do Programa Nacional de Reforma Agrária (PNRA), objetivando o assentamento dos trabalhadores rurais e a atividade complementar de regularização fundiária. Os ocupantes de terras públicas da União deverão preencher os seguintes requisitos:

(i) não serem proprietários de imóvel rural em qualquer parte do território nacional;

(ii) não serem beneficiários do PNRA, salvo as situações admitidas pelo INCRA;

(iii) explorar o imóvel por mais de um ano e um dia com uso adequado dos recursos naturais;

(iv) comprovar morada habitual no imóvel;

(v) terem como atividade principal a agropecuária no imóvel pretendido;

(vi) terem o imóvel cadastrado no Sistema Nacional de Cadastro Rural.

Se a área familiar já estiver medida e demarcada, e preenchidos estes requisitos, os ocupantes receberão o título de domínio (título definitivo), que é inegociável pelo prazo de 10 anos. Quando estas famílias atendem os requisitos, mas não estão em áreas demarcadas, firmam um contrato de concessão de uso com o INCRA, intransferível e inegociável, até que a medição e demarcação topográfica se realize.

O quinto requisito para que os ocupantes de terras públicas da União regularizem a situação fundiária (terem como atividade principal a agropecuária) é preocupante por representar um fator estimulador ao desmatamento (a maioria das comunidades amostradas no Amapá, por exemplo, possuem lotes com altas taxas de cobertura florestal), assim como outras ações governamentais anteriores (o antigo ITR, por exemplo - Brito, 1999). Porém, uma Portaria anterior do INCRA (477, de 1999), cria a modalidade de Projeto de Desenvolvimento Sustentável para populações tradicionais cuja subsistência é baseada no extrativismo, agricultura familiar e outras atividades de 
baixo impacto ambiental. A Portaria estabelece a concessão de uso em regime comunial, através de associações e cooperativas.

A Instrução Normativa 41 ainda assegura o acesso dos beneficiários dos projetos de reforma agrária às linhas de crédito disponíveis à agricultura familiar segundo as condições estabelecidas pelo Conselho Monetário Nacional. Reza também a implantação de infra-estrutura, compreendendo estradas, água e energia elétrica nos projetos de assentamento. 
A3 - instrução normativa 4 do IBAMA

\author{
DIÁRIO OFICIAL, SEÇÃO 1, DE 30 DE DEZEMBRO DE 1998. \\ MINISTÉRIO DO MEIO AMBIENTE, DOS RECURSOS HÍDRICOS E DA AMAZÔNIA \\ LEGAL \\ RENOVÁVEIS \\ INSTITUTO BRASILEIRO DO MEIO AMBIENTE E DOS RECURSOS NATURAIS
}

\title{
INSTRUÇÃO NORMATIVA Nº 4 de 28 de dezembro de 1998.
}

O PRESIDENTE DO INSTITUTO BRASILEIRO DO MEIO AMBIENTE E DOS RECURSOS NATURAIS RENOVÁVEIS - IBAMA, no uso das atribuições previstas no artigo 24, incisos I e III da Estrutura Regimental anexa ao Decreto $n^{\circ} 78$, de 05 de abril de 1991 e o artigo 83, inciso XIV, do Regimento Interno aprovado pela Portaria Ministerial GM/MINTER $n^{\circ} 445$, de 16 de agosto de 1989 , tendo em vista o disposto no art. 15 da Lei 4.771 , de 15 de setembro de 1965, e no § 2o, do artigo 3o, do Decreto 2.788, de 28 de setembro de 1998 ,

Considerando a necessidade de regulamentar o manejo florestal Comunitário, fixando seus critérios e parâmetros;

Considerando o conjunto de experiências em curso de manejo florestal de forma comunitária na Amazônia;

Considerando as reivindicações realizadas pelas populações tradicionais que praticam a exploração de recursos florestais na bacia amazônica;

Considerando a carência de normas específicas para a prática do manejo florestal na bacia amazônica de forma comunitária;

Considerando a necessidade de ampliar as alternativas econômicas de produção, condizentes com as especificidades da região amazônica;

Considerando os resultados das consultas realizadas, no segundo semestre de 1998, junto às entidades dos segmentos de produção e pesquisa, governamentais e não governamentais sobre a exploração e o manejo sustentável de forma comunitária, resolve:

Art. $1^{\circ}$ - A exploração de recursos florestais na bacia amazônica de forma comunitária, por intermédio de associações de proprietários ou legítimos possuidores de glebas rurais com área de até quinhentos hectares, poderá ser realizada mediante um único plano de manejo florestal sustentável simplificado, que aglutine glebas individuais, respeitado o limite máximo de quinhentos hectares anualmente manejados.

Art. 20 - Para efeito desta Instrução Normativa, a Associação deverá apresentar ao IBAMA o seu Estatuto e Regimento Interno.

Art. $3^{\circ}$ - O IBAMA designará, na medida das possibilidades, Engenheiro Florestal ou Agrônomo habilitado do seu quadro de pessoal, ou por ele credenciado, para auxiliar as Associações na elaboração de seus Planos de Manejo Florestal Sustentável Simplificado.

Art. $4^{\circ}$ - Quando se tratar de manejo florestal comunitário, a SUPES atenderá as solicitações requisitadas pela Associação, estipulando prazos para o cumprimento de eventuais pendências relativas ao Plano de Manejo Florestal Sustentável.

Parágrafo único - A Associação poderá fazer uso da prerrogativa constante no caput deste artigo no máximo duas vezes consecutivas.

\section{DAS SANÇÕES ADMINISTRATIVAS E PENAIS}

Art. $5^{\circ}$ - A Associação coletivamente e seus sócios individualmente, detentores de plano de manejo florestal, que deixarem de cumprir as operações nele estabelecidas ou determinadas pelas SUPES, sem justificativa, ficam sujeitos às sanções previstas nas 
respectivas Instruções Normativas reguladoras de cada modalidade de plano de manejo, sem prejuízo das sanções previstas na lei 9.605, de 12 de fevereiro de 1998 e seu regulamento.

DAS DISPOSIÇÕES FINAIS

Art. $6^{\circ}$ - O IBAMA poderá celebrar convênios, acordos ou contratos com pessoa física ou jurídica para o fiel cumprimento desta Portaria.

Art. $7^{\circ}$ - Esta Instrução Normativa entra em vigor na data de sua publicação.

Art. $8^{\circ}$ - Revogam-se as disposições em contrário.

EDUARDO DE SOUZA MARTINS

PRESIDENTE DO IBAMA 


\section{A4 - Questionário levantamento outubro de 1999}

\section{Ações para o Desenvolvimento Florestal do Estado do Amapá}

$\mathrm{N}^{\circ}$ do

Questionário

Local e Data da entrevista

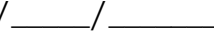

1- Dados Gerais sobre o(a) entrevistado

1.1- Nome $1.2-$

Sexo

1.3- Apelido

1.4- Idade anos

1.5- Estado

Civil

1.6- Moradia Atual

(comunidade/município)

1.7- Anode chegada na comunidade 1.8- Veio de

onde?

1.9- Qual era a sua atividade naquele

lugar?

2- Caracterização da Comunidade (somente com a(s) lideranças se possível verificar com outros entrevistados)

2.1- Nome da Comunidade $\mathrm{N}^{\circ}$ de famílias

residentes

2.2- Tempo de existência da comunidade Forma de ocupação

3- Evolução do uso da terra (somente com a(s) lideranças se possível verificar com outros entrevistados)

3.1 Evolução do uso dos recursos florestais da comunidade fazer um croqui com ajuda de mapas ou imagem de satélite)

\begin{tabular}{|l|l|l|l|}
\hline Cobertura Vegetal & Início de Exploração (ano__ & Atual & Observação \\
\hline Mata Virgem & & & \\
\hline Mata Explorada & & & \\
\hline Várzea Inundável & & & \\
\hline Capoeira Grossa & & & \\
\hline Capoeira Fina & & & \\
\hline Pasto Sujo (enjuquirado) & & & \\
\hline Pasto Limpo & & & \\
\hline Culturas Permanentes & & & \\
\hline
\end{tabular}




\begin{tabular}{|l|l|l|l|}
\hline Roça & & & \\
\hline Pasto Nativo & & & \\
\hline
\end{tabular}

4- Situação Legal da Terra (somente com a(s) lideranças se possível verificar com outros entrevistados)

4.1- Situação jurídica das terras da comunidade (usar o croqui para localizar as terras)

\begin{tabular}{|l|l|l|l|l|l|}
\hline $\begin{array}{l}\text { Modalidade de Acesso } \\
\text { (todos lotes disponíveis) }\end{array}$ & Área ou \% & Ano de acesso & Preço atual (R\$) & $\begin{array}{l}\text { Documento de } \\
\text { Propriedade }\end{array}$ & Observações \\
\hline Compra & & & & & \\
\hline Posse antiga reconhecida & & & & & \\
\hline Ocupação pacífica & & & & & \\
\hline Ocupação conflituosa & & & & & \\
\hline Herança & & & & & \\
\hline Arrendamento & & & & & \\
\hline Concessão de uso & & & & & \\
\hline Outras & & & & & \\
\hline
\end{tabular}

5- Meios de Acesso a Comunidade (transporte de produtos) - se possível localizar no croqui

5.1- Meios de acesso $\quad \square$ Rio $\square$ Estrada Asfaltada $\square$ Estrada Piçarra $\square$ Estrada de terra $\square$ jangadas (

5.2- Trânsito no acesso principal: $\quad \square$ Ano todo $\square$ Só no verão

5.3- Meios de transporte $\quad \square$ Barco $\quad \square$ Ônibus $\quad \square$ Caminhão/camionete $\square$ Transporte Próprio

Outro meio

(discriminar transporte próprio/outro meio)

5.4- Regularidade do transporte $\quad \square$ Diária $\quad \square$ Semanal $\square$ Quinzenal $\square$ Mensal $\quad \square$ Outra

(

\section{6- Infra-estrutura Local}

6.1- Na sua comunidade tem escola? $\square$ sim $\square$ não. Até que

série?

6.2- Tem posto médico? $\square \operatorname{sim} \square$ não Quem administra?

Funciona? $\square \operatorname{sim}$

não

6.3- Tem igreja(s)?

Qual(is)?

6.4- Tem sede social? $\square$ sim $\square$ não $\quad$ Qual? (barracão de igreja, sedes de clubes de futebol...)

6.5- Tem comércios? $\square$ sim $\square$ não. De

que? 
6.6- Tem energia elétrica? Qual a

fonte?

6.7- Tem escritório da agência de assistência técnica

(RURAP)?

$6.8-$

Outros?

-

\section{7- Organização Social}

7.1- O Sr. tem algum parente morando na comunidade? $\quad \square \operatorname{sim} \quad \square$ não

Quantos?

Qual a relação de parentesco (pai, mãe, irmãos (as),

etc...)

Nomes

7.2- É sóciode alguma organização com trabalho na comunidade? (Sindicato, Associações, Cantinas, etc...)

$\square \operatorname{sim} \square$ não

Quais (nomes

completos)

7.3- Na comunidade tem:

\begin{tabular}{|l|l|l|l|l|}
\hline Organização & Ano de Fundação & É filiado? & Tempo de filiação & Quem administra? \\
\hline Cooperativa & & & & \\
\hline Associação & & & & \\
\hline Cantina & & & & \\
\hline Clube de Mães & & & & \\
\hline Caixa Agrícola & & & & \\
\hline & & & & \\
\hline
\end{tabular}

7.4- Exerce algum cargo na organização $\square \operatorname{sim} \quad \square$ não Qual?_ Desde quando?

7.5- O Sr. participa (ou) de alguma atividade coletiva da comunidade? $\quad \square \operatorname{sim} \quad \square$ não

\begin{tabular}{|l|l|l|l|l|}
\hline Atividade & Com quem? & Onde? & Para que? & Observações \\
\hline Reunião & & & & \\
\hline Seminário & & & & \\
\hline Mutirão & & & & \\
\hline Celebração da Igreja & & & & \\
\hline & & & & \\
\hline
\end{tabular}

7.6- O Sr.(a) reconhece algma liderança na comunidade? $\square$ sim $\square$ não Quem? 
Porque?

7.7- Que tipo de liderança que esta pessoa exerce:
$\square$ Democrática
Centralizadora

7.8- Quando surgem conflitos (problemas) na comunidade como são resolvidos

$\square$ Evita-se falar no problema

$\square$ O conflito não é resolvidopor causa dos impasses

$\square$ O conflito é resolvido sempre com um vitorioso

$\square$ Procura-se a conciliação entre as partes

7.9- Quais as suas expectativas em relação ao desenvolvimento da comunidade?

7.10- Qual(is) a(s) atividade (s) são mais importantes para este desenvolvimento?

7.11- Tem alguma entidade fazendo trabalhos de assistência ou político na comunidade?

Qual?

\section{8- Mão-de-Obra}

8.1- Disponibilidade de mão-de-obra

\begin{tabular}{|l|l|l|l|l|l|}
\hline Sexo & Idade (anos) & Quantidade ou \% & Escolaridade & $\begin{array}{l}\text { Experiência } \\
\text { profissional }\end{array}$ & $\begin{array}{l}\text { Trabalhou com } \\
\text { madeira ? }\left(^{*}\right)\end{array}$ \\
\hline Mulheres & $(21-40)$ & & & & \\
\hline & $(40-60)$ & & & & \\
\hline & $>60$ & & & & \\
\hline & & & & & \\
\hline & $(21-40)$ & & & & \\
\hline & $(40-60)$ & & & & \\
\hline & $>60$ & & & & \\
\hline
\end{tabular}

$\left(^{*}\right)$ 1- Extração

2- Transporte

3- Serraria

8.2- O Sr. já participou de algum tipo de treinamento? $\quad \square \operatorname{sim} \quad \square$ não

Qual?

Duração Com

quem?

Onde? Para

quê? 
8.3- O que o Sr. entende sobre “Manejo

Florestal"?

\section{9- Fontes de Renda}

9.1- Atividades

\begin{tabular}{|l|l|l|l|}
\hline Atividade & Vendas & \multicolumn{1}{|c|}{ Preço (R\$) } & Quem comprou? \\
\hline & Quantidade (Un.) & & \\
\hline Agrícola & & & \\
\hline Criação Pequenos Animais & & & \\
\hline Criação Grandes Animais & & & \\
\hline Outras & & & \\
\hline & & & \\
\hline
\end{tabular}

9.2- O Sr. recebe algum dinheiro de fora do estabelecimento agrícola? $\quad \square \operatorname{sim} \quad \square$ não. Que tipo/valor/regularidade?

$\square$ pensão, $\mathrm{R} \$$ $\square$ aposentadoria R $\$$ $\square$ salário R\$ $\square$ auxílio externo (especificar auxílio e regularidade) $\mathrm{R} \$$

9.3- Produção e Comercialização de Produtos Extrativos

\begin{tabular}{|l|l|l|l|l|}
\hline Produtos & Produção (anual) & \multicolumn{1}{l|}{ Vendas } & Preço (R\$) & Quem comprou? \\
\hline Andiroba & & Quantidade & & \\
\hline Borracha & & & & \\
\hline Castanha & & & & \\
\hline Cupuaçu & & & & \\
\hline Copaíba & & & & \\
\hline Mel & & & & \\
\hline Açaí & & & & \\
\hline Palmito & & & & \\
\hline Camarão & & & & \\
\hline Outros & & & & \\
\hline
\end{tabular}

\section{0- Acesso ao Crédito Agrícola}

10.1- O Sr. recebe(eu) algum apoio a fundo perdido? $\quad \square \operatorname{sim} \quad \square$ não

10.2- Se recebe(eu), qual o projeto, época e benefícios

resultantes

10.3- Qual(is) as fontes de crédito que você

conhece?

10.4- O Sr. já tinha recebido algum tipo de financiamento bancário? $\quad \square \quad$ sim $\quad \square$ não

10.5- Qual? Aonde e

quando? 
10.6- Para

quê?

-

10.7- Que tipo de financiamento(s) mais recente(s) o Sr.

recebeu?

10.8- Em que banco o Sr. conseguiu este

financiamento?

10.9- Quem lhe apoiou para conseguir este

financiamento?

\section{1- Produção florestal}

11.1- Produção e Comercialização das Espécies Florestais no último ano de 1998

\begin{tabular}{|c|c|c|c|c|c|c|}
\hline \multirow{2}{*}{ Espécies } & \multirow[b]{2}{*}{$\begin{array}{l}\text { Árvores vendidas } \\
\text { Toras }\left(\mathrm{m}^{3}\right)\end{array}$} & \multicolumn{3}{|l|}{ Preço } & \multirow[b]{2}{*}{$\begin{array}{l}\text { Quem } \\
\text { comprou? (*) }\end{array}$} & \multirow[b]{2}{*}{ Observações } \\
\hline & & $\begin{array}{l}\text { Em pé ou árvore } \\
\left(\mathrm{R} \$ \mathrm{~m}^{3}\right)\end{array}$ & Tora $\left(\mathrm{R} \$ / \mathrm{m}^{3}\right)$ & $\begin{array}{l}\text { Processada } \\
\left(\mathrm{R} \$ / \mathrm{m}^{3}\right)\end{array}$ & & \\
\hline \multicolumn{7}{|c|}{ Maçaranduba } \\
\hline \multicolumn{7}{|l|}{ Angelim } \\
\hline & & & & & & \\
\hline & & & & & & \\
\hline & & & & & & \\
\hline & & & & & & \\
\hline
\end{tabular}

$\left.{ }^{*}\right)$ - Madeireiro; Toreiro; Serraria

11.2- Produção de Madeira

Produção (m³/ano)

1996

1997

1998

\begin{tabular}{|l|l|l|l|}
\hline & & & \\
\hline & & & \\
\hline
\end{tabular}

11.3- Tipo de Exploração

( ) Mecanizada (Trator)

( ) Catraca (Motosserra e caminhão)

( ) Manual (Machado e estiva)

( ) Outros

11.4- Responsável pela exploração (\%)

( ) Empresa

( ) Comunidade

( ) Outros
\% de Produção

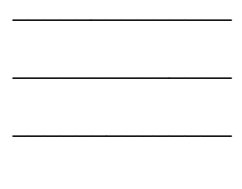




\title{
A5 - Questionário levantamento outubro de 2000
}

\author{
Comunidades do Amapá \\ Nome da Comunidade
}

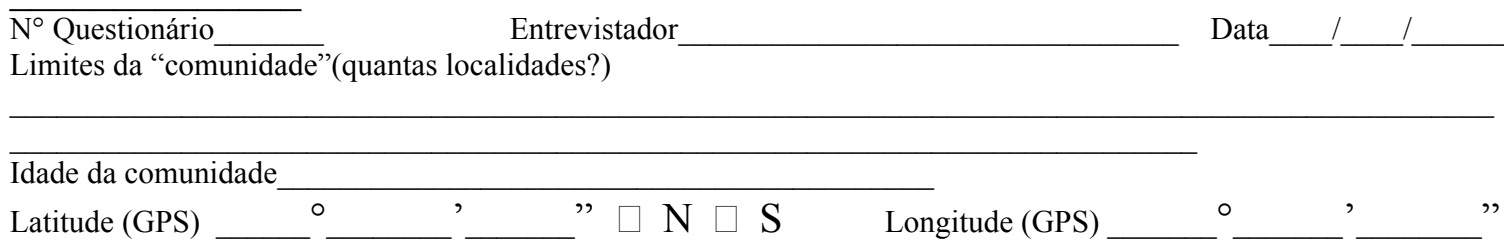

A. PERFIL DOS ENTREVISTADOS

1. Nome

2. Idade

3. Tamanho da família

4. Anos na comunidade

5. Estado de Origem

6. O que fazia lá?

7. O que faz agora?

8. Função do entrevistado na Comunidade? É líder comunitário?

B. POPULAÇÃO DA COMUNIDADE pessoas

10. $\mathrm{N}^{\circ}$ de Famílias residentes

11. Tamanho médio das famílias

12. Tamanho de família dos 2 ou 3 vizinhos + próximos

13. Faixa de Idade

\begin{tabular}{|l|l|}
\hline Faixa de Idade & Número de Pessoas (\%) \\
\hline$<12$ anos & \\
\hline 12 a 20 anos & \\
\hline 20 a 50 anos & \\
\hline$>60$ anos & \\
\hline
\end{tabular}

C. ÁREA DA COMUNIDADE

14. Tamanho médio dos lotes (comparar campos de futebol, tarefas, etc.).

15. Área Total da

Comunidade

D. SITUAÇÃO FUNDIÁRIA

16. Qual a história de ocupação das áreas? (projeto de colonização, posse antiga, compra de áreas, terra devoluta etc.?)

$\overline{\text { 17. Que documentos fundiários }}$ possuem?

\section{E. COBERTURA VEGETAL}




\section{CROQUI DA DISPOSIÇÃO DOS TIPOS DE COBERTURA VEGETAL (VERSO)}

\begin{tabular}{|l|l|}
\hline COBERTURA VEGETAL & Área (ha) ou \% \\
\hline Açaizal nativo & \\
\hline Campos & \\
\hline Capoeiras & \\
\hline Culturas Permanentes e Roças & \\
\hline Pastos & \\
\hline Igapós e Várzea inundável & \\
\hline Florestas Exploradas não madeireiros & \\
\hline Florestas Exploradas Madeireiros & \\
\hline Outros & \\
\hline
\end{tabular}

F. INFRA-ESTRUTURA

19. ESCOLAS

Há escolas? Até que série?

No Total de alunos?

Se não há na comunidade, existe próxima? (distância e meio de acesso)

20. POSTOS MÉDICOS Marque S para Sim e N para Não

Existe Unidade de Saúde ? ( ) Há médico ( ), Enfermeiros ( ), Agentes de saúde ( ) Freqüência de Atendimento? ( No de vezes / unidade de tempo)

O que fazem quando ocorre picada de cobra?

Para as comunidades sem Posto de Saúde, verificar como é feito o atendimento ( deslocamento para a unidade de saúde mais próxima, por exemplo)

22. ENERGIA ELÉTRICA

Fonte (elétrica, termoelétrica etc)

Regularidade (todo o dia ou apenas um turno

?)

23. ACESSO

Meios de Acesso (estrada rio). Podem ser usados durante todo o ano?

Condições de acesso (qualidade da

estrada)

24. SEDES SOCIAIS.

Existe (— Tipo de sede ? (associação, cooperativa, centros comunitários, futebol, igreja etc) 
G. ORGANIZAÇ̃̃O SOCIAL

\begin{tabular}{|l|l|l|}
\hline ORGANIZAÇÃO & $N^{\circ}$ de Filiados & Participação (\%) \\
\hline 1. Associação & & \\
\hline 2. Cooperativa & & \\
\hline 3. Sindicatos & & \\
\hline 4. & & \\
\hline 5. & & \\
\hline
\end{tabular}

25. Quais as atividades coletivas da comunidade? (reuniões, mutirões, festas, eventos cívicos, igrejas, etc.). Descrever nível de participação e freqüência em que ocorrem?

(1)

(2)

(3)

\section{H. EXPERIÊNCIA FLORESTAL}

26. Trabalhou com madeira?

27. Quantas Famílias na comunidade trabalharam

$(\%)$ ?

28. Participam do processamento, extração ou apenas vendem madeira em

pé?

29. Recebe(u) alguma assistência técnica florestal? Caso positivo, caracterizar o tipo (corte de árvores, inventário, marcenaria etc) e freqüência

30. Principais Espécies madeireiras extraídas?

31. Tem serraria na comunidade? Produção média anual (tora e serrado)

I. ECONOMIA LOCAL

\begin{tabular}{|l|l|}
\hline ATIVIDADE & Participação na Economia (\%) \\
\hline 1.Madeira Processada & \\
\hline 2.Madeira Bruta & \\
\hline 3.Extrativismo - Açaí & \\
\hline 3.Extrativismo - Palmito & \\
\hline 3.Extrativismo - Castanha & \\
\hline 3.Extrativismo - Látex & \\
\hline 3. Extrativismo - Outros & \\
\hline 4. Agricultura & \\
\hline 5. Pecuária & \\
\hline 6. Outros & \\
\hline
\end{tabular}


32. Descrever principais atividades (produtos, mercado )

Observações (financiamentos, funcionamento das serrarias locais, atividades econômicas, etc.) 


\section{A6 - Lista das comunidades visitadas e suas coordenadas geográficas.}

Tabela 18. Lista das comunidades visitadas no levantamento, coordenadas geográficas obtidas com auxílio de GPS e período em que foram conduzidas as entrevistas (agosto de 1999 e/ou outubro de 2000).

\begin{tabular}{|c|c|c|c|c|c|c|c|}
\hline \multirow[t]{2}{*}{ ID } & \multirow[t]{2}{*}{ Comunidade } & \multirow[t]{2}{*}{ Município } & \multirow[t]{2}{*}{ Latitude } & \multirow[t]{2}{*}{ Longitude } & \multicolumn{2}{|c|}{ Ano da Entrevista } & \multirow[t]{2}{*}{ Entrevistas } \\
\hline & & & & & 1999 & 2000 & \\
\hline 1 & Assent. Vila do Maracá & Mazagão & $0^{\circ} 19,039^{\prime} \mathrm{S}$ & $51^{\circ} 56,569^{\prime}$ & $\mathrm{X}$ & $\bar{X}$ & 3 \\
\hline 2 & Santa Clara & Mazagão & $0^{\circ} 32,968^{\prime} \mathrm{S}$ & $52^{\circ} 10,631^{\prime}$ & $\mathrm{X}$ & & 1 \\
\hline 3 & Santo Antonio do Camaipi & Mazagão & $0^{\circ} 03^{\prime} 10,3^{\prime \prime} \mathrm{S}$ & $51^{\circ} 33^{\prime} 37,2^{\prime \prime}$ & $\mathrm{X}$ & & 1 \\
\hline 4 & Vila Betel & Mazagão & $0^{\circ} 35^{\prime} 54^{\prime \prime} \mathrm{S}$ & $51^{\circ} 37^{\prime} 42^{\prime \prime}$ & $\mathrm{X}$ & $\mathrm{X}$ & 3 \\
\hline 5 & Santa Maria do Curuça & Mazagão & $0^{\circ} 30^{\prime} 18,4^{\prime \prime} \mathrm{S}$ & $51^{\circ} 29^{\prime} 14,1^{\prime \prime}$ & $\mathrm{X}$ & $\mathrm{X}$ & 2 \\
\hline 6 & Santa Ana & Mazagão & $0^{\circ} 48^{\prime} 17,4^{\prime \prime} \mathrm{S}$ & $51^{\circ} 42^{\prime} 53^{\prime \prime}$ & $\mathrm{X}$ & $\mathrm{X}$ & 4 \\
\hline 7 & Santo Antonio do Mutuacá & Mazagão & $0^{\circ} 14^{\prime} 7,3^{\prime \prime} \mathrm{S}$ & $51^{\circ} 21^{\prime} 51,4^{\prime \prime}$ & $\mathrm{X}$ & & 1 \\
\hline 8 & Sororoca & Mazagão & $0^{\circ} 19,047^{\prime} \mathrm{S}$ & $51^{\circ} 56,612^{\prime}$ & $\mathrm{X}$ & & 1 \\
\hline 9 & São José do Maracá & Mazagão & $0^{\circ} 26^{\prime} 47,2^{\prime \prime} \mathrm{S}$ & $51^{\circ} 29^{\prime} 18,3^{\prime \prime}$ & $\mathrm{X}$ & & 1 \\
\hline 10 & Ramal do Pioneiro & Mazagão & $0^{\circ} 06^{\prime} 4,1^{\prime \prime} \mathrm{S}$ & $\begin{array}{lll}51^{\circ} 30^{\prime} & 11,9^{\prime \prime}\end{array}$ & $\mathrm{X}$ & $\mathrm{X}$ & 3 \\
\hline 11 & São Benedito do Rio Urubueno & Mazagão & $0^{\circ} 13^{\prime} 57,6^{\prime \prime} \mathrm{S}$ & $51^{\circ} 19^{\prime} 16,2^{\prime \prime}$ & $\mathrm{X}$ & & 1 \\
\hline 12 & Salvador Deus Proverá & Mazagão & $0^{\circ} 22^{\prime} 54,8^{\prime \prime} \mathrm{S}$ & $51^{\circ} 24^{\prime} 3,9^{\prime \prime}$ & $\mathrm{X}$ & & 1 \\
\hline 13 & Maranata & Mazagão & $0^{\circ} 32^{\prime} 10,3 " \mathrm{~S}$ & $51^{\circ} 32^{\prime} 51,1^{\prime \prime}$ & $\mathrm{X}$ & $\mathrm{X}$ & 3 \\
\hline 14 & Tambaqui & Mazagão & $0^{\circ} 43^{\prime} 18,2^{\prime \prime} \mathrm{S}$ & $51^{\circ} 40^{\prime} 37,8^{\prime \prime}$ & $\mathrm{X}$ & $\mathrm{X}$ & 2 \\
\hline 15 & Bispo & Mazagão & $0^{\circ} 41^{\prime} 20^{\prime \prime} \mathrm{S}$ & $51^{\circ} 38^{\prime} 47,9^{\prime \prime}$ & $\mathrm{X}$ & $\mathrm{X}$ & 2 \\
\hline 16 & Espinhel & Mazagão & $0^{\circ} 15^{\prime} 19,7^{\prime \prime} \mathrm{S}$ & $51^{\circ} 21^{\prime} 31,3^{\prime \prime}$ & $\mathrm{X}$ & & 1 \\
\hline 17 & Assent. do Silvestre & Serra do Navio & $0^{\circ} 56^{\prime} 38,9^{\prime \prime} \mathrm{N}$ & $51^{\circ} 57^{\prime} 19,1^{\prime \prime}$ & $\mathrm{X}$ & $\mathrm{X}$ & 5 \\
\hline 18 & Água Branca & Serra do Navio & $00^{\circ} 56^{\prime} 18^{\prime \prime} \mathrm{N}$ & $51^{\circ} 59^{\prime} 48^{\prime \prime}$ & $\mathrm{X}$ & & 1 \\
\hline 19 & Capivara & Serra do Navio & $0^{\circ} 57^{\prime} 31,6^{\prime \prime} \mathrm{N}$ & $51^{\circ} 00^{\prime} 55,4^{\prime \prime}$ & $\mathrm{X}$ & & 1 \\
\hline 20 & Jararaca & Serra do Navio & $0^{\circ} 57^{\prime} 58,7 " \mathrm{~N}$ & $51^{\circ} 58^{\prime} 49,1^{\prime \prime}$ & $\mathrm{X}$ & & 1 \\
\hline 21 & Perpetuo Socorro & Serra do Navio & $0^{\circ} 56^{\prime} 41,2^{\prime \prime} \mathrm{N}$ & $51^{\circ} 59^{\prime} 48,6^{\prime \prime}$ & $\mathrm{X}$ & & 1 \\
\hline 22 & Sete Ilhas & Pedra Branca & $1^{\circ} 03^{\prime} 15^{\prime \prime} \mathrm{N}$ & $52^{\circ} 18^{\prime} 34,5^{\prime \prime}$ & $\mathrm{X}$ & & 1 \\
\hline 23 & Tucano I & Pedra Branca & $1^{\circ} 5,801^{\prime} \mathrm{N}$ & $52^{\circ} 23,619^{\prime}$ & $\mathrm{X}$ & $\mathrm{X}$ & 4 \\
\hline 24 & Água Fria & Pedra Branca & $0^{\circ} 48^{\prime} 35,8^{\prime \prime} \mathrm{N}$ & $51^{\circ} 58^{\prime} 54,1^{\prime \prime}$ & $\mathrm{X}$ & $\mathrm{X}$ & 4 \\
\hline 25 & Tucano II & Pedra Branca & $1^{\circ} 5,309^{\prime} \mathrm{N}$ & $52^{\circ} 28,196^{\prime}$ & $\mathrm{X}$ & & 1 \\
\hline 26 & Triunfo & Ferreira Gomes & $0^{\circ} 50^{\prime} 40^{\prime \prime} \mathrm{N}$ & $51^{\circ} 2^{\prime} 48^{\prime \prime}$ & $\mathrm{X}$ & & 1 \\
\hline 27 & São Raimundo & Ferreira Gomes & $0^{\circ} 59^{\prime} 29,1^{\prime \prime} \mathrm{N}$ & $50^{\circ} 56^{\prime} \quad 6,2^{\prime \prime}$ & $\mathrm{X}$ & & 1 \\
\hline 28 & Assent. Nova Vida & Ferreira Gomes & $0^{\circ} 59^{\prime} 26^{\prime \prime} \mathrm{N}$ & $51^{\circ} 16^{\prime} 51,3^{\prime \prime}$ & $\mathrm{X}$ & & 1 \\
\hline 29 & Assent. Nova Canãa & Porto Grande & $0^{\circ} 37^{\prime} 47,7^{\prime \prime} \mathrm{N}$ & $\begin{array}{lll}51^{\circ} & 42^{\prime} 05^{\prime \prime}\end{array}$ & $\mathrm{X}$ & & 1 \\
\hline 30 & Ramal do Cachaço & Serra do Navio & $00^{\circ} 54^{\prime} 29^{\prime \prime} \mathrm{N}$ & $52^{\circ} 02^{\prime} 35^{\prime \prime}$ & $\mathrm{X}$ & $\mathrm{X}$ & 4 \\
\hline 31 & São Sebastião do Cachaco & Porto Grande & $0^{\circ} 56,654^{\prime} \mathrm{N}$ & $52^{\circ} 11,322^{\prime}$ & $\mathrm{X}$ & & 1 \\
\hline 32 & Assent. do Munguba & Porto Grande & $0^{\circ} 37,46^{\prime} \mathrm{N}$ & $51^{\circ} 49,44^{\prime}$ & $\mathrm{X}$ & $\mathrm{X}$ & 3 \\
\hline 33 & Santa Maria do Vila Nova & Porto Grande & $0^{\circ} 35,133^{\prime} \mathrm{N}$ & $51^{\circ} 44,293^{\prime}$ & $\mathrm{X}$ & & 1 \\
\hline 34 & São Francisco do Iratapuru & Laranjal do Jarí & $0^{\circ} 34^{\prime} 5,6^{\prime \prime} \mathrm{S}$ & $52^{\circ} 34^{\prime} 41,7^{\prime \prime}$ & $\mathrm{X}$ & & 1 \\
\hline
\end{tabular}


Tabela 18. Lista das comunidades visitadas no levantamento, coordenadas geográficas obtidas com auxílio de GPS e período em que foram conduzidas as entrevistas (agosto de 1999 e/ou outubro de 2000).

\begin{tabular}{|c|c|c|c|c|c|c|c|}
\hline \multirow[t]{2}{*}{ ID } & \multirow[t]{2}{*}{ Comunidade } & \multirow[t]{2}{*}{ Município } & \multirow[t]{2}{*}{ Latitude } & \multirow[t]{2}{*}{ Longitude } & \multicolumn{2}{|c|}{ Ano da Entrevista } & \multirow[t]{2}{*}{ Entrevistas } \\
\hline & & & & & 1999 & 2000 & \\
\hline 35 & Cachoeira de S.Antonio do Jarí & Laranjal do Jarí & $0^{\circ} 39^{\prime} 1,4^{\prime \prime} \mathrm{S}$ & $52^{\circ} 30^{\prime} 30,7^{\prime \prime}$ & $\mathrm{X}$ & & 1 \\
\hline 36 & Padaria & Laranjal do Jarí & $0^{\circ} 42^{\prime} 35,8^{\prime \prime} \mathrm{S}$ & $52^{\circ} 29^{\prime} 47,8^{\prime \prime}$ & $\mathrm{X}$ & & 1 \\
\hline 37 & Água Branca & Laranjal do Jarí & $0^{\circ} 32,98^{\prime} \mathrm{S}$ & $52^{\circ} 10,629^{\prime}$ & $\mathrm{X}$ & & 1 \\
\hline 38 & Tira couro & Laranjal do Jarí & $0^{\circ} 44^{\prime} 37,9^{\prime \prime} \mathrm{S}$ & $52^{\circ} 27^{\prime} 24^{\prime \prime}$ & $\mathrm{X}$ & & 1 \\
\hline 39 & Aterro do Muriacá & Vitória do Jarí & $0^{\circ} 54,835^{\prime} \mathrm{S}$ & $52^{\circ} 8,078^{\prime}$ & $\mathrm{X}$ & & 1 \\
\hline 40 & Matauaú & Vitória do Jarí & $1^{\circ} 7,475^{\prime} \mathrm{S}$ & $51^{\circ} 59,755^{\prime}$ & $\mathrm{X}$ & & 1 \\
\hline 41 & Jarílândia & Vitória do Jarí & $1^{\circ} 2,992^{\prime} \mathrm{S}$ & $51^{\circ} 59,770^{\prime}$ & $\mathrm{X}$ & & 1 \\
\hline 42 & Marinheiro de Fora & Macapá & $0^{\circ} 54,308^{\prime} \mathrm{N}$ & $50^{\circ} 1,317^{\prime}$ & $\mathrm{X}$ & $\mathrm{X}$ & 3 \\
\hline 43 & Igaçaba & Macapá & $1^{\circ} 2,128^{\prime} \mathrm{N}$ & $50^{\circ} 0,218^{\prime}$ & $\mathrm{X}$ & $\mathrm{X}$ & 4 \\
\hline 44 & Jaburuzinho & Macapá & $0^{\circ} 51,401^{\prime} \mathrm{N}$ & $50^{\circ} 14,636^{\prime}$ & $\mathrm{X}$ & & 1 \\
\hline 45 & Buritizal & Macapá & $0^{\circ} 52,313 \mathrm{~N}$ & $50^{\circ} 5,561^{\prime}$ & $\mathrm{X}$ & $\mathrm{X}$ & 3 \\
\hline 46 & Livramento do Bailique & Macapá & $00^{\circ} 54,308^{\prime} \mathrm{N}$ & $50^{\circ} 03,945^{\prime}$ & $\mathrm{X}$ & $\mathrm{X}$ & 3 \\
\hline 47 & Menino Deus & Mazagão & $00^{\circ} 4^{\prime} 35^{\prime \prime} \mathrm{S}$ & $51^{\circ} 43^{\prime} 12^{\prime \prime}$ & & $\mathrm{X}$ & 1 \\
\hline 48 & Assentamento Nova Colina & Porto Grande & $00^{\circ} 31^{\prime} 45^{\prime \prime} \mathrm{N}$ & $51^{\circ} 20^{\prime} 28^{\prime \prime}$ & & $\mathrm{X}$ & 1 \\
\hline 49 & Açaituba & Mazagão & $00^{\circ} 44^{\prime} 46^{\prime \prime} \mathrm{S}$ & $51^{\circ} 41^{\prime} 51^{\prime \prime}$ & & $\mathrm{X}$ & 2 \\
\hline 50 & Irapi & Mazagão & $00^{\circ} 40^{\prime} 02^{\prime \prime} \mathrm{S}$ & $51^{\circ} 38^{\prime} 16^{\prime \prime}$ & & $\mathrm{X}$ & 1 \\
\hline 51 & Filadélfia & Mazagão & $00^{\circ} 36^{\prime} 30^{\prime \prime} \mathrm{S}$ & $51^{\circ} 36^{\prime} 39^{\prime \prime}$ & & $\mathrm{X}$ & 1 \\
\hline 52 & Retiro do Ariramba & Mazagão & $00^{\circ} 36^{\prime} 25^{\prime \prime} \mathrm{S}$ & $51^{\circ} 36^{\prime} 45^{\prime \prime}$ & & $\mathrm{X}$ & 1 \\
\hline 53 & Santo Antonio & Mazagão & $00^{\circ} 32^{\prime} 12^{\prime \prime} \mathrm{S}$ & $51^{\circ} 32^{\prime} 32^{\prime \prime}$ & & $\mathrm{X}$ & 1 \\
\hline 54 & S.Antonio/Braço do Ajuruxi & Mazagão & $00^{\circ} 32^{\prime} 43^{\prime \prime} \mathrm{S}$ & $51^{\circ} 35^{\prime} 22^{\prime \prime}$ & & $\mathrm{X}$ & 2 \\
\hline 55 & Limão do Curuá & Macapá & $00^{\circ} 45^{\prime} 47^{\prime \prime} \mathrm{N}$ & $50^{\circ} 10^{\prime} 08^{\prime \prime}$ & & $\mathrm{X}$ & 4 \\
\hline 56 & Franquinho & Macapá & $00^{\circ} 56^{\prime} 37^{\prime \prime} \mathrm{N}$ & $50^{\circ} 04^{\prime} 28^{\prime \prime}$ & & $\mathrm{X}$ & 2 \\
\hline
\end{tabular}




\section{A7 - Número de famílias e área de uso estimada}

Tabela 19. Número de famílias e área total estimada das comunidades amostradas.

\begin{tabular}{|c|c|c|c|c|}
\hline ID & Comunidade & Município & $\begin{array}{c}\mathrm{N}^{\circ} \text { de } \\
\text { Famílias }\end{array}$ & $\begin{array}{l}\text { Área } \\
\text { (ha) }\end{array}$ \\
\hline 1 & Assent. Vila do Maracá & Mazagão & 724 & 363.500 \\
\hline 2 & Santa Clara & Mazagão & 19 & - \\
\hline 3 & Santo Antonio do Camaipi & Mazagão & 7 & - \\
\hline 4 & Vila Betel & Mazagão & 28 & 1.400 \\
\hline 5 & Santa Maria do Curuça & Mazagão & 19 & - \\
\hline 6 & Santa Ana & Mazagão & 8 & - \\
\hline 7 & Santo Antonio do Mutuacá & Mazagão & 20 & - \\
\hline 8 & Sororoca & Mazagão & 17 & - \\
\hline 9 & São José do Maracá & Mazagão & 11 & - \\
\hline 10 & Ramal do Pioneiro & Mazagão & 20 & 1.850 \\
\hline 11 & São Benedito do Rio Urubueno & Mazagão & 7 & 350 \\
\hline 12 & Salvador Deus Proverá & Mazagão & 4 & - \\
\hline 13 & Maranata & Mazagão & 20 & 1.850 \\
\hline 14 & Tambaqui & Mazagão & 8 & - \\
\hline 15 & Bispo & Mazagão & 4 & - \\
\hline 16 & Espinhel & Mazagão & 60 & - \\
\hline 17 & Assent. do Silvestre & Serra do Navio & 45 & 2.250 \\
\hline 18 & Água Branca & Serra do Navio & 600 & - \\
\hline 19 & Capivara & Serra do Navio & 17 & - \\
\hline 20 & Jararaca & Serra do Navio & 10 & 1.500 \\
\hline 21 & Perpetuo Socorro & Serra do Navio & 80 & - \\
\hline 22 & Sete Ilhas & Pedra Branca & 42 & - \\
\hline 23 & Tucano I & Pedra Branca & 30 & 3.000 \\
\hline 24 & Água Fria & Pedra Branca & 62 & 31.000 \\
\hline 25 & Tucano II & Pedra Branca & 50 & - \\
\hline 26 & Triunfo & Ferreira Gomes & 39 & - \\
\hline 27 & São Raimundo & Ferreira Gomes & 46 & - \\
\hline 28 & Assent. Nova Vida & Ferreira Gomes & 50 & 9.500 \\
\hline 29 & Assent. Nova Canãa & Porto Grande & 240 & 20.500 \\
\hline 30 & Ramal do Cachaço & Serra do Navio & 30 & 3.000 \\
\hline 31 & São Sebastião do Cachaco & Porto Grande & 55 & 5.700 \\
\hline 32 & Assent. do Munguba & Porto Grande & 301 & 37.500 \\
\hline 33 & Santa Maria do Vila Nova & Porto Grande & 129 & 12.900 \\
\hline
\end{tabular}


Tabela 19. Número de famílias e área total estimada das comunidades amostradas.

\begin{tabular}{|c|c|c|c|c|}
\hline ID & Comunidade & Município & $\begin{array}{c}\mathrm{N}^{\circ} \text { de } \\
\text { Famílias }\end{array}$ & $\begin{array}{c}\text { Área } \\
\text { (ha) }\end{array}$ \\
\hline 34 & São Francisco do Iratapuru & Laranjal do Jarí & 37 & - \\
\hline 35 & Cachoeira de S.Antonio do Jarí & Laranjal do Jarí & 23 & - \\
\hline 36 & Padaria & Laranjal do Jarí & 95 & - \\
\hline 37 & Água Branca & Laranjal do Jarí & 66 & - \\
\hline 38 & Tira couro & Laranjal do Jarí & 15 & - \\
\hline 39 & Aterro do Muriacá & Vitória do Jarí & 17 & - \\
\hline 40 & Matauaú & Vitória do Jarí & 10 & - \\
\hline 41 & Jarílândia & Vitória do Jarí & 71 & - \\
\hline 42 & Marinheiro de Fora & Macapá & 36 & 700 \\
\hline 43 & Igaçaba & Macapá & 22 & 900 \\
\hline 44 & Jaburuzinho & Macapá & 35 & - \\
\hline 45 & Buritizal & Macapá & 38 & 400 \\
\hline 46 & Livramento do Bailique & Macapá & 17 & 200 \\
\hline 47 & Menino Deus & Mazagão & 20 & 1.000 \\
\hline 48 & Assentamento Nova Colina & Porto Grande & 8 & 22.700 \\
\hline 49 & Açaituba & Mazagão & 5 & - \\
\hline 50 & Irapi & Mazagão & 7 & 2.178 \\
\hline 51 & Filadélfia & Mazagão & 6 & 300 \\
\hline 52 & Retiro do Ariramba & Mazagão & 6 & 2.000 \\
\hline 53 & Santo Antonio & Mazagão & 6 & 100 \\
\hline 54 & S.Antonio/Braço do Ajuruxi & Mazagão & 12 & - \\
\hline 55 & Limão do Curuá & Macapá & 40 & 3.000 \\
\hline 56 & Franquinho & Macapá & 16 & 1.435 \\
\hline
\end{tabular}




\section{REFERÊNCIAS BIBLIOGRÁFICAS}

AGRICULTURA não tem futuro no país. Jornal O Liberal. Caderno Atualidades, Belém, 25 set. 2000. p.10.

AMAPÁ. Governo do Estado. Amapá sustentável para o século 21. Macapá, 1999. $62 \mathrm{p}$.

AMAPÁ. Governo do Estado. Amapá, um modelo de desenvolvimento sustentável. http//www.amapa.gov.br. (10/11/2000).

ARAUJO, H.J.B. Índices técnicos da exploração e transformação madeireira em pequenas áreas sob manejo florestal no Projeto de Colonização Pedro Peixoto AC. Rio Branco: Embrapa, CPA/AC, 1999. 29 p.

ARIMA, E.; MACIEL, N.; UHL, C. Oportunidades para o desenvolvimento do estuário amazônico. Belém: Imazon, 1998. 40p. (Série Amazônia , 15)

ARMELIN, M.J.C. II oficina sobre manejo florestal comunitário. São Paulo: Amigos da Terra - Amazônia Brasileira; WWF; State University of New York., 2000. 24p.

BANCO DA AMAZÔNiA SA. Perfil atual do Banco da Amazônia: 2000. Belém, 2000. 54p. (Relatório de Atividades)

BECKER, B.K. Cenários a curto prazo para o desenvolvimento da Amazônia. Brasília: Ministério do Meio Ambiente, 1999. 43 p. (Série Cadernos do Núcleo de apoio às políticas integradas para a Amazônia) 
BECKER, B.K.; MIRANDA, M. (Org.) A geografia política do desenvolvimento sustentável. Rio de Janeiro: Editora UFRJ, 1997. 494 p.

BRITO, M. As implicações do novo Imposto Territorial Rural. Jornal Gazeta Mercantil. Caderno Opinião, Belém, 15 mar. 1999. p.2.

BURSZTYN, M.; IRACHANDE, A.M.; NUNES, B.F. et al. Avaliação do PGAIAmapá para a área prioritária 1 - Região Sul do Amapá. Macapá: Governo do Estado do Amapá, 1997. 36 p. (Relatório de Avaliação do PGAI - Amapá)

CASTRO, M.C. Desenvolvimento sustentável e gestão ambiental na formulação de políticas públicas: a experiência do Estado do Amapá. Macapá: Governo do Estado do Amapá, 1998. 84p.

DIEGUES, A.C.S. A caixeta no Vale do Ribeira: estudo socioeconômico da população vinculada à extração e ao desdobro da caixeta. São Paulo: EDUSP, 1991. 120 p.

DIEGUES, A.C.S. O mito moderno da natureza intocada. São Paulo: NUPAUB, 1994. $163 \mathrm{p}$.

DIEGUES, A.C.S.; NOGARA, P.J. O nosso lugar virou parque. São Paulo: NUPAUB, 1994. $187 \mathrm{p}$.

DIEGUES, A.C.S. Desmatamento e modos de vida na Amazônia. São Paulo: Nupaub, 1999. $146 \mathrm{p}$.

GABEIRA, G. L. Síntese da economia brasileira. Rio de Janeiro: Confederação Nacional do Comércio, 1999.

HALL, A. O papel das ong's na resolução de conflitos para o desenvolvimento sustentável. In: BECKER, B.K.; MIRANDA, M. (Org.) A geografia política do desenvolvimento sustentável. Rio de Janeiro: Editora UFRJ, 1997. p.273-296. 
HOMMA, A.K.O. Extrativismo vegetal na Amazônia, limites e oportunidades. Brasília: Embrapa, Ministério da Agricultura, do Abastecimento e da Reforma, 1993. 202 p.

INSTITUTO BRASILEIRO DE GEOGRAFIA E ESTATÍSTICA Contagem da população, 1996. Brasília, 1997. CD-ROM.

INSTITUTO BRASILEIRO DE GEOGRAFIA E ESTATÍSTICA. Mapa de solos da Amazônia Legal. Brasília, 1989. CD-ROM.

INSTITUTO NACIONAL DE COLONIZAÇÃO E REFORMA AGRÁRIA. Legislação. http://www.incra.gov.br. (12/09/2000).

LENÁ, P. Novos atores sociais, desenvolvimento sustentável e organizações não governamentais. In: BECKER, B.K.; MIRANDA, M. (Org.) A geografia política do desenvolvimento sustentável. Rio de Janeiro: Editora UFRJ, 1997. p.273-296.

LEROY, J.P. Da comunidade local às dinâmicas microrregionais na busca do desenvolvimento sustentável. In: BECKER, B.K.; MIRANDA, M. (Org.) A geografia política do desenvolvimento sustentável. Rio de Janeiro: Editora UFRJ, 1997. p.251-272.

MATTOS, M.M.; UHL, C. Perspectivas econômicas e ecológicas da pecuária na Amazônia oriental na década de 90: o caso de Paragominas. In: ALMEIDA, O.T. (Ed.) A evolução da fronteira amazônica: oportunidades para um desenvolvimento sustentável. Belém: Imazon, 1996. p. 39-65.

NEPSTAD, D.C.; MOREIRA, A.G.; ALENCAR, A.A. A floresta em chamas: origens, impactos e prevenção de fogo na Amazônia: programa piloto para a proteção das florestas tropicais do Brasil. Brasília: Banco Mundial, 1999. 180 p.

NITSCH, M.; KASPER, A. Pequenos produtores na zona Bragantina (PA). Brasília: CNPq; IBAMA; MCT, 1998. 35 p. 
PRADO, A.C. Diretrizes para uma política florestal no Brasil. Brasília: Ministério do Meio Ambiente, 1995. 171 p.

RITCHIE, B.; MCDOUGALL, C.; HAGGITH, M. et al. Critérios e indicadores de sustentabilidade em florestas manejadas por comunidades: um guia introdutório. Belém - PA, CIFOR, 2000. 82p.

SERRÃO, E.A.S.; NEPTASD, D.; WALKER, R. Upland agricultural anda forestry development in the Amazon: sustainability, criticality and resilience. Ecological Economics, v.18, p.3-13, 1996.

SCHNEIDER, R.R.; ARIMA, E.; VERÍSSIMO, A. et al. Amazônia sustentável: limitantes e oportunidades para o desenvolvimento rural. Brasília: Banco Mundial, 2000.57 p.

SMERALDI, R.; PAGNOCCHESCHI, B.; MAY, P.H. Políticas públicas coerentes para a região amazônica. Amigos da Terra-Amazônia Brasileira, São Paulo, 1994, $79 \mathrm{p}$.

SMERALDI, R. Políticas públicas para a Amazônia. São Paulo: Amigos da TerraAmazônia Brasileira, 1998. 97p.

SMERALDI R.; MAY, P. H.; PAGNOCCHESCHI, B. et al. Políticas públicas coerentes para uma Amazônia sustentável: o desafio da inovação e o Programa Piloto. São Paulo: Amigos da Terra-Amazônia Brasileira, 1998. 189 p.

SMITH, N.; DUBOIS, J.; CURRENT, D. et al. Experiências agroflorestais na Amazônia brasileira: restrições e oportunidades. Brasília: Programa Piloto para a Proteção das Florestas Tropicais do Brasil, 1998. 120 p.

UHL, C.; AMARAL, P.; BARRETO, P. et al.. Uma abordagem integrada de pesquisa sobre o manejo dos recursos naturais na Amazônia. Belém: Imazon, 1997. 28p. (Série Amazônia, 7) 
VERÍSSIMO, A.; LIMA, E. Caracterização dos pólos madeireiros da Amazônia Legal. Belém: Imazon, 1999. (Documento Interno)

VERÍSSIMO, A.; BARRETO, P.; MATTOS, M. et al. Impactos da atividade madeireira e perspectivas para o manejo sustentável da floresta numa velha fronteira da Amazônia: o caso de Paragominas. In: ALMEIDA, O.T. (Ed.) A evolução da fronteira amazônica: oportunidades para um desenvolvimento sustentável. Belém: Imazon, 1996. p. 8-37.

VERÍSSIMO, A.; CAVALCANTE, A.; VIDAL, E. et al. O setor madeireiro no Amapá: situação atual e perspectivas para o desenvolvimento sustentável. Macapá: Governo Estadual do Amapá, 1999. 78p.

VERÍSSIMO, A.; SOUZA Jr., C.; SALOMÃO, R. Identificação de áreas com potencial para criação de florestas de produção no Amapá. Macapá: Governo Estadual do Amapá, 2000. 28p.

VIDAL, E.; GERWING, J.; BARRETO, P. et al. Redução de desperdícios na produção de madeira na Amazônia. Belém: Imazon, 1997. 19p. (Série Amazônica, 5)

TONIOLO, A.; UHL, C. Perspectivas econômicas e ecológicas da agricultura na Amazônia oriental. In: ALMEIDA, O.T. (Ed.) A evolução da fronteira amazônica: oportunidades para um desenvolvimento sustentável. Belém: Imazon, 1996. p. 68-96. 